\title{
Use of Residential Smart Appliances for Peak-Load Shifting and Spinning Reserves
}

\section{Cost/Benefit Analysis}

Chellury (Ram) Sastry

Rob Pratt

December 2010
Viraj Srivastava

Shun Li

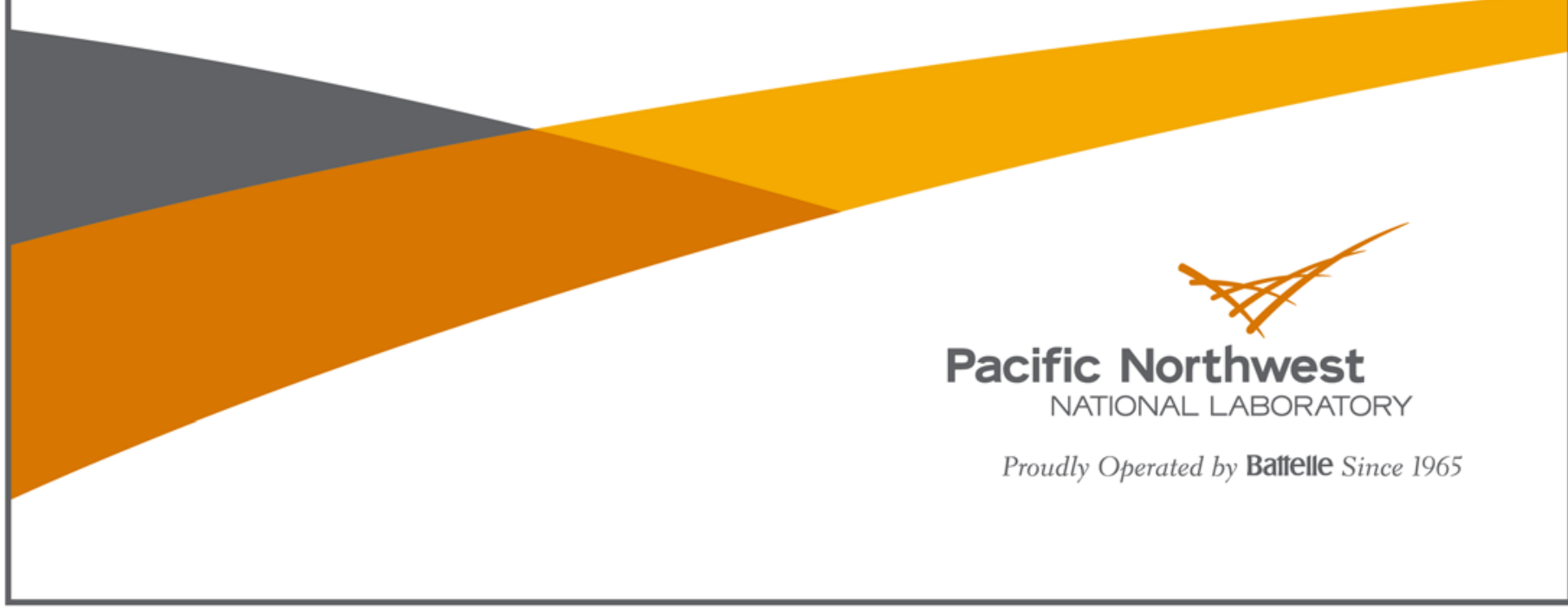




\title{
DISCLAIMER
}

This report was prepared as an account of work sponsored by an agency of the United States Government. Neither the United States Government nor any agency thereof, nor Battelle Memorial Institute, nor any of their employees, makes any warranty, express or implied, or assumes any legal liability or responsibility for the accuracy, completeness, or usefulness of any information, apparatus, product, or process disclosed, or represents that its use would not infringe privately owned rights. Reference herein to any specific commercial product, process, or service by trade name, trademark, manufacturer, or otherwise does not necessarily constitute or imply its endorsement, recommendation, or favoring by the United States Government or any agency thereof, or Battelle Memorial Institute. The views and opinions of authors expressed herein do not necessarily state or reflect those of the United States Government or any agency thereof.

\author{
PACIFIC NORTHWEST NATIONAL LABORATORY \\ operated by \\ BATTELLE \\ for the \\ UNITED STATES DEPARTMENT OF ENERGY \\ under Contract DE-AC05-76RL01830 \\ Printed in the United States of America \\ Available to DOE and DOE contractors from the \\ Office of Scientific and Technical Information, \\ P.O. Box 62, Oak Ridge, TN 37831-0062; \\ ph: (865) 576-8401 \\ fax: (865) 576-5728 \\ email: reports@adonis.osti.gov \\ Available to the public from the National Technical Information Service, \\ U.S. Department of Commerce, 5285 Port Royal Rd., Springfield, VA 22161 \\ ph: (800) 553-6847 \\ fax: (703) 605-6900 \\ email: orders@ntis.fedworld.gov \\ online ordering: http://www.ntis.gov/ordering.htm
}




\section{Use of Residential Smart Appliances for Peak-Load Shifting and Spinning Reserves}

\section{Cost/Benefit Analysis}

Chellury (Ram) Sastry Viraj Srivastava

Rob Pratt

Shun Li

December 2010

Prepared for

the U.S. Department of Energy

under Contract DE-AC05-76RL01830

Pacific Northwest National Laboratory

Richland, Washington 99352 



\section{Abstract}

In this report, we present the results of an analytical cost/benefit study of residential "smart appliances" "from a utility/grid perspective in support of a joint stakeholder ${ }^{2}$ petition to the ENERGY STAR program within the Environmental Protection Agency (EPA) and Department of Energy (DOE). The goal of the petition is in part to provide appliance manufacturers incentives to hasten the production of smart appliances. The underlying hypothesis is that smart appliances can play a critical role in addressing some of the societal challenges, such as anthropogenic global warming, associated with increased electricity demand, and facilitate increased penetration of renewable sources of power. The appliances we consider include refrigerator/freezers, clothes washers, clothes dryers, room airconditioners, and dishwashers.

The petition requests the recognition that providing an appliance with smart grid capability, i.e., products that meet the definition of a "smart appliance," is at least equivalent to a corresponding five percent in operational machine efficiencies. It is then expected that given sufficient incentives and value propositions, and suitable automation capabilities built into smart appliances, residential consumers will be adopting these smart appliances and will be willing participants in addressing the aforementioned societal challenges by more effectively managing their home electricity consumption.

The analytical model we utilize in our cost/benefit analysis consists of a set of user-definable assumptions such as the definition of "on-peak" (hours of day, days of week, months of year), the expected percentage of normal consumer electricity consumption (also referred to as appliance loads) that can shifted from peak hours to off-peak hours, the average power rating of each appliance, etc. Based on these assumptions, we then formulate what the wholesale grid operating-cost savings, or "benefits," would be if the "smart" capabilities of appliances were invoked, and some percentage of appliance loads were shifted away from peak hours to run during off-peak hours, and appliance loads served powersystem balancing needs such as spinning reserves that would otherwise have to be provided by generators. The rationale is that appliance loads can be curtailed for about ten minutes or less in response to a grid contingency without any diminution in the quality of service to the consumer. We then estimate the wholesale grid operating-cost savings based on historical wholesale-market clearing prices (location marginal and spinning reserve) from major wholesale power markets in the United States. The savings derived from the smart grid capabilities of an appliance are then compared to the savings derived from a five percent increase in traditional operational machine efficiencies, referred to as "cost" in this report, to determine whether the savings in grid operating costs (benefits) are at least as high as or higher than the operational machine efficiency credit (cost).

\footnotetext{
1 "Smart Appliances" are capable of either shifting their time of operation or curtailing their operation temporarily upon request. A more detailed definition is presented in Section 1.1.

${ }^{2}$ Stakeholders include Association of Home Appliance Manufacturers (AHAM), American Council for an EnergyEfficient Economy, Natural Resources Defense Council, Consumer Federation of America, and many others.
} 



\section{Executive Summary}

The work reported herein was performed by the Pacific Northwest National Laboratory (PNNL) and funded by the U.S. Department of Energy, Office of Electricity Delivery and Energy Reliability (OE).

In this report, we present the results of our cost/benefit analysis of residential smart appliances. The appliances we consider include refrigerator/freezers (R/F), clothes washers (CW), clothes dryers (CD), room air conditioners (RAC), and dishwashers (DW). By "benefits," we mean the annual savings in the power-grid wholesale operating costs as a result of

1. smart appliances shifting their operation from on-peak hours to off-peak hours, thereby reducing the need for peak-power producing generators

2. smart appliances being able to temporarily curtail their operation (for up to ten minutes) thereby providing spinning reserves ${ }^{1}$ to the power grid as opposed to generators in the event of a contingency.

These benefits are estimated based on historical locational marginal prices (LMP) and spinning reserve (SR) prices from various markets in the United States operated and coordinated by well-known Independent System Operators (ISO) and Regional Transmission Operators (RTO) including Pennsylvania-New Jersey-Maryland (PJM) Interconnection, California ISO (CAISO), New York ISO (NYISO), and Electric Reliability Council of Texas (ERCOT).

For the purpose of this report, we define "cost" of an appliance as a percentage "credit" that joint stakeholders are seeking from the EPA to recognize the equivalent or higher benefits that could be achieved through smart grid capabilities as compared to operational efficiencies, as well as to incentivize appliance makers to manufacture smart appliances. The smart appliance credit that is being sought out by stakeholders in their joint petition is five percent. In absolute monetary terms, this cost is estimated by applying the five percent credit on each appliance's annual grid operating expenses, which in turn are evaluated based on historical wholesale LMP prices from major markets.

The cost/benefit analysis was undertaken using an analytical model that is a function of a set of input assumptions. These include definitions of on-peak hours, and the days of a week and months of a year those peak hours are expected to occur. They also include annual average electricity consumption by each appliance estimated based on AHAM data and Department of Energy (DOE) standards and test procedures.

In addition to these assumptions, the benefits of each smart appliance depend on how much appliance load is actually available for peak-load shifting and spinning reserves. First we define what we refer to as "Net Fraction of On-Peak Load Available to Shift.", This is the product of three other fractions:

1. "Fraction of Customers Receiving Grid Signals and Communicating these to an Appliance," i.e. those consumers who have the capability to receive pricing and other grid signals from a utility or third

\footnotetext{
${ }^{1}$ Detailed explanation of what spinning reserves mean and their valuation in wholesale markets is presented in Sections 2.1 and 3.4.3.

${ }^{2}$ Appliance load refers to total electricity consumption, and during peak periods all of this load or part of it can be shifted. In the case of refrigerators and freezers, appliance load refers to defrost load or ice-making load, and it is these loads that are available for shifting during peak periods.
} 
party energy service providers and passing them on to an appliance to manage its consumption. These signals could be received through a smart meter as part of smart grid advanced metering infrastructure (AMI), or through some other interface into the home. And the signals can either reach the smart appliances directly, or through some intermediary mechanism such as a home gateway or what AHAM refers to as a "hub". 3

2. Of those customers who have the capability described in \#1, some will override, and the remaining will be willing to shift load; these we define as "Fraction of Customers Willing to Shift On-Peak Load."

3. Finally, among those customers who do not override and are willing to shift peak load as in \#2, some may not be willing to shift their entire on-peak load. This is captured through "Fraction of On-Peak Load that Willing Customers Shift."

Similar to "Net Fraction of On-Peak Load Available to Shift," we also define "Net Fraction of Load Available for Spinning Reserves" with the caveat that appliance load is available for spinning reserves all the time. In other words, any time appliances are operating, they can be interrupted for a short duration, up to 10 minutes or so, by either shutting off completely or reducing their electricity consumption in response to a spinning-reserve request signal (for example, a dryer operating with two heating elements might continue to operate but with only one heating element on). The "Net Fraction of Load Available for Spinning Reserves" is a product of three other fractions:

1. "Fraction of Customers Receiving Grid Signals and Communicating these to an Appliance" as described above.

2. Of those customers who have the capability described in \#1, only some of them will be willing to make their appliances available for spinning reserves; these we define as "Fraction of Customers Willing to Provide Spinning Reserves."

3. Finally, among those customers who do not override a request for spinning reserves as in $\# 2$, some may not be willing to make their entire load available for spinning reserves even for a short duration. This is captured through "Fraction of Appliance Load Reduced for Spinning Reserves."

Finally, an important and key assumption we make in our analysis is what is referred to as "consumer behavior feedback effect:" Studies ${ }^{4}$ have shown that providing energy-usage feedback to consumers based on AMI \& other mechanisms has resulted in reduced energy consumption. In this work, we hypothesize that through the use of smart appliances, such energy-use feedback mechanisms can further be enhanced. In particular, we assume that an average reduction of $3-6$ percent per appliance in electricity consumption will be possible due to change in customer behavior as a result of the feedback provided to them through the use of smart appliances.

\footnotetext{
${ }^{3}$ Association of Home Appliance Manufacturers (AHAM). 2010. Assessment of Communication Standards for Smart Appliances: The Home Appliance Industry's Technical Evaluation of Communication Protocols. Accessed December 9, 2010 at http://www.aham.org/ht/a/GetDocumentAction/i/50696.

${ }^{4}$ American Council for an Energy Efficient Economy. 2010. Advanced Metering Initiatives and Residential Feedback Programs: A Meta-Review for Household Electricity-Saving Opportunities. Available at http://www.aceee.org/research-report/e105
} 
The smart appliance cost/benefit model we have developed is based on all of the above assumptions, and the End-Use Load and Consumer Assessment Program $\left(\right.$ ELCAP $\left.^{5}\right)$ load shapes for daily usage patterns. Note that although ELCAP data is based on 1989 appliance consumption ratings, we extrapolate ELCAP data to current energy levels for use in our model. Through ELCAP data, our model estimates the on-peak and off-peak consumption of each appliance. Then, based on these estimates, and on annual hourly average energy market clearing prices (LMP), the annual wholesale production cost in operating a given appliance is evaluated. The savings derived from shifting of a given percentage of peak loads to offpeak periods are also estimated.

When it comes to spinning reserves, our model estimates total appliance load available during onpeak and off-peak periods, taking into account how much load is shifted from peak to off-peak hours. Historical annual hourly spinning-reserve market clearing prices are invoked to value on-peak and offpeak loads serving as sources of spinning reserves.

Finally, the total operational cost savings or "benefits" are those arising from peak-load shifting and spinning reserves. The five percent smart-appliance credit is applied to the total annual operating cost of a given appliance to estimate the monetary value of the credit based on operational machine efficiencies which is the "cost" applied toward making an appliance smart.

In order to get a range of estimates for the benefits and costs, we consider two sets of assumptions: a set of best-case or "optimistic" set of assumptions that lead to highest possible benefits and a set of lowend or "pessimistic" assumptions leading to lower benefits.

Shown in Table 1.1 are the highest possible benefit-to-cost ratios of various appliances based on the "optimistic" set of assumptions.

Table 1-1. Benefit-to-Cost Ratios of Smart Appliances Based on "Optimistic" Assumptions

\begin{tabular}{|c|c|c|c|c|c|c|}
\hline & DW & CW & RAC & Freezer & Refrigerator & Dryer \\
\hline PJM 2006 & $528 \%$ & $563 \%$ & $483 \%$ & $539 \%$ & $536 \%$ & $680 \%$ \\
\hline ERCOT 2008 & $1484 \%$ & $1612 \%$ & $884 \%$ & $880 \%$ & $876 \%$ & $1053 \%$ \\
\hline NYISO 2008 & $854 \%$ & $934 \%$ & $420 \%$ & $357 \%$ & $355 \%$ & $462 \%$ \\
\hline NYISO 2006 & $600 \%$ & $660 \%$ & $459 \%$ & $346 \%$ & $344 \%$ & $442 \%$ \\
\hline CAISO 2008 & $523 \%$ & $583 \%$ & $351 \%$ & $314 \%$ & $312 \%$ & $396 \%$ \\
\hline
\end{tabular}

Shown in Table 1.2 are the low-end benefit-to-cost ratios of various appliances based on "pessimistic" set of assumptions.

\footnotetext{
${ }^{5}$ Pratt RG, CC Conner, EE Richman, KG Ritland, WF Sandusky, and ME Taylor. 1989. Description of Electric Energy Use in Single-Family Residences in the Pacific Northwest. (End-Use Load and Consumer Assessment Program [ELCAP]). DOE/BP-13795-21, prepared for Bonneville Power Administration by Pacific Northwest Laboratory, Richland, Washington.
} 
Table 1-2. Benefit-to-Cost Ratios of Smart Appliances Based on "Pessimistic" Assumptions

\begin{tabular}{|c|c|c|c|c|c|c|}
\hline & DW & CW & RAC & Freezer & Refrigerator & Dryer \\
\hline PJM 2006 & $137 \%$ & $135 \%$ & $131 \%$ & $152 \%$ & $151 \%$ & $209 \%$ \\
\hline ERCOT 2008 & $374 \%$ & $372 \%$ & $296 \%$ & $234 \%$ & $232 \%$ & $343 \%$ \\
\hline NYISO 2008 & $250 \%$ & $248 \%$ & $145 \%$ & $113 \%$ & $113 \%$ & $149 \%$ \\
\hline NYISO 2006 & $184 \%$ & $184 \%$ & $151 \%$ & $112 \%$ & $112 \%$ & $151 \%$ \\
\hline CAISO 2008 & $168 \%$ & $169 \%$ & $138 \%$ & $106 \%$ & $105 \%$ & $140 \%$ \\
\hline
\end{tabular}

As can be seen from Table 1.1 and $\mathrm{d}$ Table 1.2, in all the markets, in either optimistic or pessimistic assumption scenarios, the benefit-to-cost ratio for all appliances exceeds 100 percent. This is especially the case for the optimistic scenario, in which the benefits overwhelmingly exceed the cost as shown in Table 1.1. This means that the annual benefits from having smart grid capabilities in an appliance are greater than an equivalent five percent increase in operational machine efficiencies. The expectation then is that if ENERGY STAR adopts this proposal for a five percent incentive for smart appliances it will facilitate the growth of the smart-appliance industry.

A major extension of this work would be to translate benefits that were evaluated in terms of savings in wholesale power production costs to savings in retail costs and the resulting benefits to rate paying customers. Since the utilities' operating and capital costs are reduced to the extent that smart appliances displace peak load capacity and spinning reserves, their need to recover these costs through retail rates is similarly reduced. In the case of regulated utilities, they periodically appear before a state's public utility commission to make the case for their rates by documenting their costs and defining retail rates to recover them. For unregulated public utilities, this same process is applied, albeit less formally, in setting retail rates. Hence, retail rates will be lower than they would be without the smart appliances, since they lower operating and capital costs at the wholesale level. It behooves the regulators (public utility commissions or governing boards) to ensure that appropriate credit for the cost reductions provided by smart appliances goes toward reducing the rates of residential customers.

This is, admittedly, an indirect mechanism for rewarding consumers for purchasing such an appliance, or-alternatively - for compensating them for a slight reduction in appliance efficiency as a means of reimbursing the manufacturer for the "smarts" designed into the appliance. It will be far preferable to reward consumers directly with a credit on their bills for supplying such services to the grid, but this must await the adoption of retail rates that more truly reflect the true, dynamic costs of providing electricity, including spinning reserves. Meanwhile, adopting a mechanism that indirectly benefits customers through the retail rate recovery process is a way to create market pull and an initial base of smart appliances that will help lead to such an outcome. 


\section{Acknowledgments}

The Pacific Northwest National Laboratory project team would like to thank the following people and organizations for their support on the project.

U.S. Department of Energy, Office of Electricity Delivery and Energy Reliability (OE)

Dan Ton, Program Manager, Smart Grid Research \& Development

Eric Lightner, Director, Smart Grid Task Force

Association of Home Appliance Manufacturers

Kevin Messner, VP Government Relations

American Council for an Energy-Efficient Economy

Steve Nadel

Northwest Power and Conservation Council

Tom Eckman

\section{General Electric Corporation}

Charlie Smith, Technology R\&D Director Government Policy \& Regulatory

\section{General Electric Corporation, Appliance Division}

David Najewicz, Manager, External Technology Programs

Whirlpool Corporation

Warwick Stirling, Global Director, Energy and Sustainability

Vincent P Anderson, Project Technical Leader - Government Programs

Pacific Northwest National Laboratory

Michael CW Kintner-Meyer, PHEV Project Manager, Smart Grid R\&D

Carla J. Raymond, Project Specialist

Kim A. Chamberlin, Administration 



\section{Acronyms and Abbreviations}

$\begin{array}{ll}\text { AHAM } & \begin{array}{l}\text { Association of Home Appliance Manufacturers } \\ \text { advanced metering infrastructure }\end{array} \\ \text { CAISO } & \text { California Independent System Operator } \\ \text { CD } & \text { clothes dryer } \\ \text { CW } & \text { clothes washer } \\ \text { DOE } & \text { Department of Energy } \\ \text { DR } & \text { demand response } \\ \text { EF } & \text { energy factor } \\ \text { ELCAP } & \text { End-Use Load and Consumer Assessment Program } \\ \text { EIA } & \text { Energy Information Administration } \\ \text { EPA } & \text { Environmental Protection Agency } \\ \text { EPRI } & \text { Electric Power Research Institute } \\ \text { ERCOT } & \text { Electricity Reliability Council of Texas } \\ \text { FERC } & \text { Federal Energy Reliability Commission } \\ \text { ISO } & \text { independent system operator } \\ \text { LMP } & \text { locational marginal pricing } \\ \text { NERC } & \text { North American Electric Reliability Corporation } \\ \text { NYISO } & \text { New York Independent System Operator } \\ \text { PJM } & \text { Pennsylvania-New Jersey-Maryland Interconnection } \\ \text { RAC } & \text { room air conditioner } \\ \text { RTO } & \text { regional transmission operator } \\ \text { SR } & \text { spinning reserves }\end{array}$





\section{Contents}

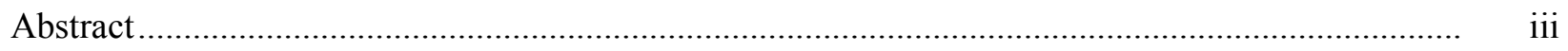

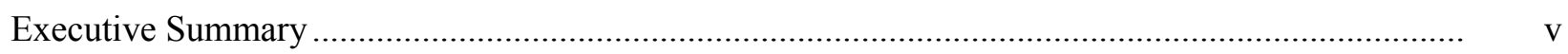

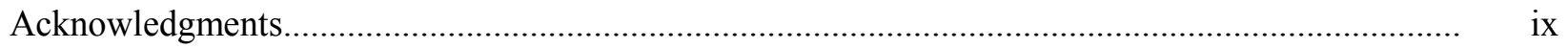

Acronyms and Abbreviations .......................................................................................... xi

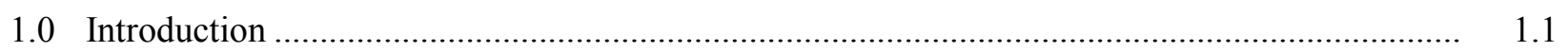

1.1 Smart Grid, Smart Appliances, and Increased Electricity Demand ................................. 1.1

1.2 Smart Grid, Smart Appliances, and Increased Penetration of Renewables....................... 1.3

2.0 Power System Reserve Requirements ......................................................................... 2.1

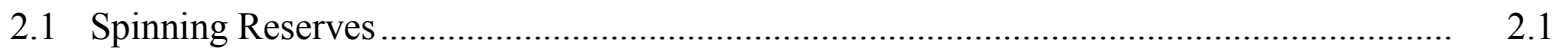

2.2 Smart Appliances as Sources of Spinning Reserves ........................................................ 2.2

3.0 Smart Appliance Cost/Benefit Analysis Model.................................................................

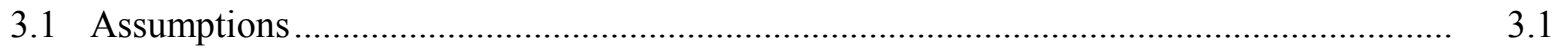

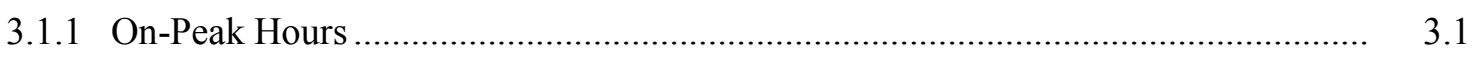

3.1.2 Annual Electricity Consumption ............................................................... 3.3

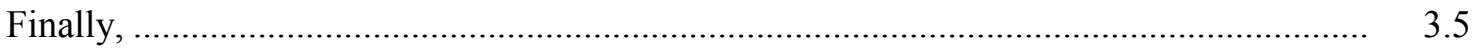

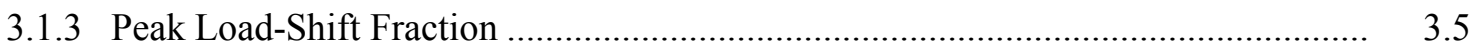

3.1.4 Load Fraction Available for Spinning Reserves ............................................... 3.6

3.1.5 Consumer Behavior Feedback Effect............................................................. 3.7

3.2 Historical Market Prices ............................................................................................... $\quad 3.9$

3.3 Appliance Load Shapes .................................................................................. 3.10

3.3.1 Clothes Dryer (CD) Load Shape .................................................................. 3.10

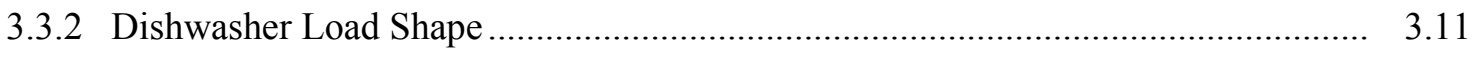

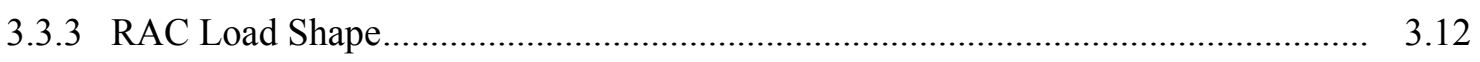

3.3.4 Freezer Load Shape ......................................................................................... 3.13

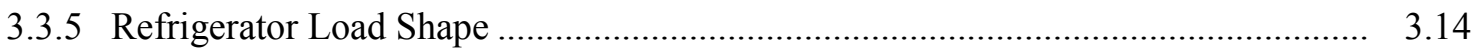

3.3.6 Clothes Washer (CW) Load Shape .................................................................. 3.15

3.4 Smart Appliance Benefits Based on Wholesale Power Production Costs .......................... 3.16

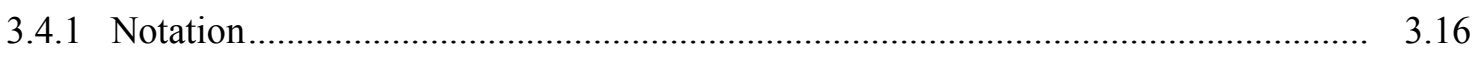

3.4.2 Smart Appliance Benefits: Peak Load Shifting .................................................. 3.17

3.4.3 Smart Appliance Benefits: Spinning Reserves.................................................. 3.18

4.0 Smart Appliance Benefit-to-Cost Ratios ........................................................................ 4.1

4.1 Benefits-to-Cost Ratio: General ................................................................................ 4.1

4.2 Benefit-to-Cost Ratios: Smart Clothes Dryers (CD) ................................................... 4.2

4.2.1 High-End Optimistic Results.......................................................................... 4.2

4.2.2 Low-End Pessimistic Results ..................................................................... 4.4

4.3 Benefit-to-Cost Ratios: Room Air Conditioners (RACs) ................................................ 4.6 
4.3.1 High-End Optimistic Results........................................................................ 4.6

4.3.2 Low-End Pessimistic Results ......................................................................... 4.8

4.4 Benefit-to-Cost Ratios: Smart Refrigerators ................................................................ 4.10

4.4.1 High-End Optimistic Results........................................................................ 4.11

4.4.2 Low-End Pessimistic Results ...................................................................... 4.13

4.5 Benefit-to-Cost Ratios: Smart Freezers....................................................................... 4.15

4.5.1 High-End Optimistic Results.................................................................... 4.15

4.5.2 Low-End Pessimistic Results ......................................................................... 4.17

4.6 Benefit-to-Cost Ratios: Smart Clothes Washers (CWs)................................................... 4.19

4.6.1 High-End Optimistic Results............................................................................ 4.19

4.6.2 Low-End Pessimistic Results ............................................................................ 4.21

4.7 Benefit-to-Cost Ratios: Smart Dishwashers (DWs) ..................................................... 4.23

4.7.1 High-End Optimistic Results........................................................................... 4.24

4.7.2 Low-End Pessimistic Results ....................................................................... 4.26

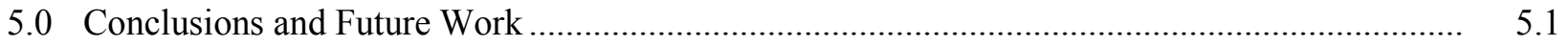

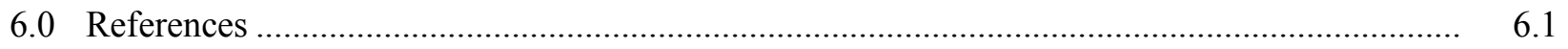

\section{Figures}

Figure 1.1. 2010 Electricity Consumption by Sector (Source: EIA) ..........................................1.1

Figure 1.2. FERC's Assessment of DR Potential (FERC 2009) ........................................................

Figure 2.1. Deployment of Contingency Reserves in Response to Sudden Loss of Generator or

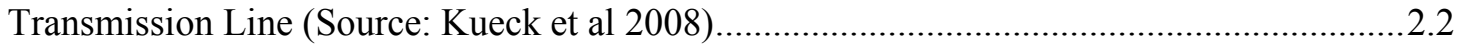

Figure 2.2. Number of Reserve Deployments versus their Duration. (Source: Kueck et al 2008)..2.3

Figure 3.1. ELCAP Dryer Load Shape for an Average Annual Day ........................................... 3.11

Figure 3.2. ELCAP Dishwasher Load Shape for an Average Annual Day ....................................12

Figure 3.3. ELCAP RAC Load Shape for an Average Summer Day ............................................13

Figure 3.4. ELCAP Freezer Load Shape for an Average Annual Day ..........................................14

Figure 3.5. ELCAP Refrigerator Load Shape for an Average Annual Day.................................3.15

Figure 3.6. ELCAP CW Load Shape for an Average Annual Day ..............................................3.16

\section{Tables}

Table 1-1. Benefit-to-Cost Ratios of Smart Appliances Based on "Optimistic" Assumptions........vii

Table 1-2. Benefit-to-Cost Ratios of Smart Appliances Based on "Pessimistic" Assumptions..... viii

Table 3-1. On-Peak, Off-Peak, and Hours to Which the Load is Shifted for all Appliances except

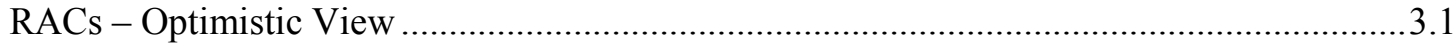

Table 3-2. On-Peak, Off-Peak, and Hours to Which the Load is Shifted for all Appliances except

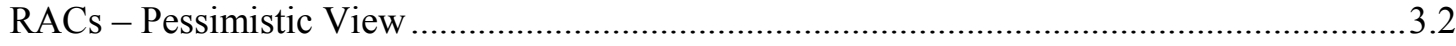


Table 3-3. On-Peak, Off-Peak, and Hours to Which the Load is Shifted for RACs - Optimistic View.....

Table 3-4. On-Peak, Off-Peak, and Hours to Which the Load is Shifted for RACs - Pessimistic View

Table 3-5. Net Fraction of On-Peak Load Available to Shift for all Appliances Sans Freezers and Refrigerators

Table 3-6. Net Fraction of Freezer and Refrigerator On-Peak Defrost and Ice-Making Loads Available to Shift

Table 3-7. Net Fraction of Load Available for Spinning Reserves Available for all Appliances ...3.7

Table 3-8. Annual Hourly Averages of LMP and Spinning Reserve Wholesale Market Clearing Prices.

Table 3-9. Hourly Averages of LMP and Spinning-Reserve Wholesale Market-Clearing Prices Over Months June through September

Table 3-10. ELCAP CD Hourly Consumption on an Average Annual Day

Table 3-11. ELCAP Dishwasher Hourly Consumption on an Average Annual Day

Table 3-12. ELCAP RAC Hourly Consumption on an Average Summer Day

Table 3-13. ELCAP Freezer Hourly Consumption on an Average Annual Day ....

Table 3-14. ELCAP Refrigerator Hourly Consumption on an Average Annual Day

Table 3-15. ELCAP CW Hourly Consumption on an Average Annual Day....

Table 4-1. CD On-Peak and Off-Peak Consumption Based on ELCAP Average Annual Day Load Shape and Optimistic Assumptions

Table 4-2. Wholesale Cost Savings from Using Smart CDs for Peak Load Shifting - Optimistic View.....

Table 4-3. Wholesale Cost Savings from Using Smart CDs for Spinning Reserves - Optimistic View

Table 4-4. Additional 6\% Savings Resulting from CD Consumption Feedback to Customers ......4.3

Table 4-5. Smart CD Benefits (Peak Load Shift + Spinning Reserves + Feedback Effect)-to-Cost Ratio - Optimistic View

Table 4-6. CD On-Peak and Off-Peak Consumption Based on ELCAP Average Annual Day Load Shape and Pessimistic Assumptions

Table 4-7. Wholesale Cost Savings from Using Smart CDs for Peak-Load Shifting - Pessimistic View

Table 4-8. Wholesale Cost Savings from Using Smart CDs for Spinning Reserves - Pessimistic View.

Table 4-9. Additional 3\% Savings Resulting from CD Consumption Feedback to Customers ...... 4.5

Table 4-10. Smart CD Benefit (Peak Load Shift + Spinning Reserves + Feedback Effect)-to-Cost Ratio - Pessimistic View

Table 4-11. RAC On-Peak and Off-Peak Consumption Based on ELCAP Average Summer Day Load Shape and Optimistic Assumptions

Table 4-12. Wholesale Cost Savings from Using Smart RACs for Peak Load Shifting Optimistic View....

Table 4-13. Wholesale Cost Savings from Using Smart RACs for Spinning Reserves - Optimistic View..... 
Table 4-14. Additional 6\% Savings Resulting from RAC Consumption Feedback to Customers .4.8

Table 4-15. Smart RAC Benefit (Peak Load Shift + Spinning Reserves + Feedback Effect)-to-

Cost Ratio - Optimistic View

Table 4-16. RAC On-Peak and Off-Peak Consumption Based on ELCAP Average Summer Day Load Shape and Pessimistic Assumptions

Table 4-17. Wholesale Cost Savings from Using Smart RACs for Peak Load Shifting Pessimistic View.

Table 4-18. Wholesale Cost Savings from Using Smart RACs for Spinning Reserves Pessimistic View.

Table 4-19. Additional 3\% Savings Resulting from RAC Consumption Feedback to Customers4.10

Table 4-20. Smart RAC Benefit (Peak Load Shift + Spinning Reserves + Feedback Effect)-toCost Ratio - Pessimistic View

We first present below in Table 4.21 the refrigerator annual on-peak and off-peak electricity consumption, including the defrost and ice-making splits, based on the optimistic assumptions presented in Section 3.1. Table 4-21. Refrigerator On-Peak and Off-Peak Consumption Based on ELCAP Average Annual Day Load Shape and Optimistic Assumptions.

Table 4-22. Wholesale Cost Savings from Using Smart Refrigerators for Peak Load Shifting Optimistic View....

Table 4-23. Wholesale Cost Savings from Using Smart Refrigerators for Spinning Reserves Optimistic View....

Table 4-24. Additional 6\% Savings Resulting from CD Consumption Feedback to Customers..4.12

Table 4-25. Smart Refrigerator Benefit (Peak Load Shift + Spinning Reserves + Feedback Effect)-to-Cost Ratio - Optimistic View

Table 4-26. Refrigerator On-Peak and Off-Peak Consumption Based on ELCAP Average Annual Day Load Shape and Pessimistic Assumptions

Table 4-27. Wholesale Cost Savings from Using Smart Refrigerators for Peak Load Shifting Pessimistic View.

Table 4-28. Wholesale Cost Savings from Using Smart Refrigerators for Spinning Reserves Pessimistic View.

Table 4-29. Additional 3\% Savings Resulting from Refrigerator Consumption Feedback to Customers

Table 4-30. Smart Refrigerator Benefits (Peak Load Shift + Spinning Reserves + Feedback Effect)-to-Cost Ratio - Pessimistic View

Table 4-31. Freezer On-Peak and Off-Peak Consumption Based on ELCAP Average Annual Day Load Shape and Optimistic Assumptions

Table 4-32. Wholesale Cost Savings from Using Smart Freezers for Peak Load Shifting Optimistic View....

Table 4-33. Wholesale Cost Savings from Using Smart Freezers for Spinning Reserves Optimistic View....

Table 4-34. Additional 6\% Savings Resulting from CD Consumption Feedback to Customers ..4.16

Table 4-35. Smart Freezer Benefit (Peak Load Shift + Spinning Reserves + Feedback Effect)-toCost Ratio - Optimistic View 
Table 4-36. Freezer On-Peak and Off-Peak Consumption Based on ELCAP Average Annual Day Load Shape and Pessimistic Assumptions

Table 4-37. Wholesale Cost Savings from Using Smart Freezers for Peak Load Shifting Pessimistic View

Table 4-38. Wholesale Cost Savings from Using Smart Freezers for Spinning Reserves Pessimistic View....

Table 4-39. Additional 3\% Savings Resulting from Freezer Consumption Feedback to Customers4.18

Table 4-40. Smart Freezer Benefits (Peak Load Shift + Spinning Reserves + Feedback Effect)-toCost Ratio - Pessimistic View

Table 4-41. CW On-Peak and Off-Peak Consumption Based on ELCAP Average Annual Day Load Shape and Optimistic Assumptions

Table 4-42. Wholesale Cost Savings from Using Smart CWs for Peak Load Shifting - Optimistic View.....

Table 4-43. Wholesale Cost Savings from Using Smart CWs for Spinning Reserves - Optimistic View.

Table 4-44. Additional 6\% Savings Resulting from CW Consumption Feedback to Customers .4.21

Table 4-45. Smart CW Benefit (Peak Load Shift + Spinning Reserves + Feedback Effect)-toCost Ratio - Optimistic View

Table 4-46. CW On-Peak and Off-Peak Consumption Based on ELCAP Average Annual Day Load Shape and Pessimistic Assumptions

Table 4-47. Wholesale Cost Savings from Using Smart CWs for Peak Load Shifting - Pessimistic View.

Table 4-48. Wholesale Cost Savings from Using Smart CWs for Spinning Reserves - Pessimistic View.

Table 4-49. Additional 3\% Savings Resulting from CW Consumption Feedback to Customers .4.23

Table 4-50. Smart CW Benefit (Peak Load Shift + Spinning Reserves + Feedback Effect)-to-Cost Ratio - Pessimistic View

Table 4-51. DW On-Peak and Off-Peak Consumption Based on ELCAP Average Annual Day Load Shape and Optimistic Assumptions

Table 4-52. Wholesale Cost Savings from Using Smart DWs for Peak Load Shifting - Optimistic View.

Table 4-53. Wholesale Cost Savings from Using Smart CWs for Spinning Reserves - Optimistic View

Table 4-54. Additional 6\% Savings Resulting from DW Consumption Feedback to Customers .4.25

Table 4-55. Smart CW Benefit (Peak Load Shift + Spinning Reserves + Feedback Effect)-to-Cost Ratio - Optimistic View

Table 4-56. DW On-Peak and Off-Peak Consumption Based on ELCAP Average Annual Day Load Shape and Pessimistic Assumptions

Table 4-57. Wholesale Cost Savings from Using Smart CWs for Peak Load Shifting - Pessimistic View

Table 4-58. Wholesale Cost Savings from Using Smart CWs for Spinning Reserves - Pessimistic View

Table 4-59. Additional 3\% Savings Resulting from DW Consumption Feedback to Customers.4.27 
Table 4-60. Smart DW Benefit (Peak Load Shift + Spinning Reserves + Feedback Effect)-to-Cost

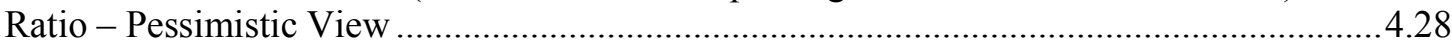




\subsection{Introduction}

In its 2010 Annual Energy Outlook, the Energy Information Administration (EIA) projects that electricity use will increase by more than 30 percent by 2035 (EIA 2010). Furthermore, it is noted that increases in electricity demand during peak periods are even more pronounced. In particular, EIA estimates that residential electricity use will increase by 23 percent from 2010-2035 due to various demographic and economic factors. As shown in Figure 1.1 below, the residential sector represents 37 percent of electricity use and is the largest consuming sector of electricity.

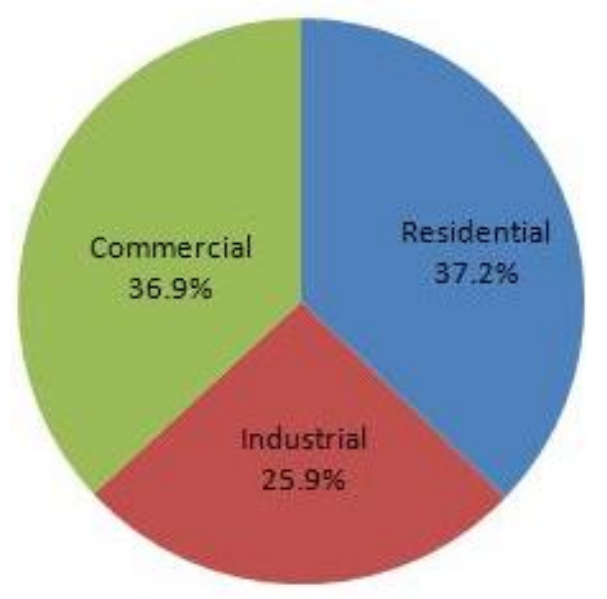

Figure 1.1. 2010 Electricity Consumption by Sector (Source: EIA)

It is therefore clear that the residential sector, the focus of this report, is critically important to managing this trend toward greater electricity demand.

\subsection{Smart Grid, Smart Appliances, and Increased Electricity Demand}

Increased use of energy efficiency measures is one well-known approach to managing increased electricity demand. At the same time, it is also very well established today that the smart grid can play a crucial role alongside and in addition to energy efficiency measures in managing increased electricity demand. For example, in his press release of August 31, 2010, DOE secretary Steven Chu quotes an Electric Power Research Institute (EPRI) study which estimates that the implementation of smart grid technologies could reduce electricity use by more than four percent annually by 2030 (DOE 2010b).

A key smart grid application that is crucial to managing electricity consumption is the notion of demand response (DR). ${ }^{1}$ DR in the residential sector is currently limited to smart thermostats, i.e., intelligent control of indoor climate by striking a compromise between residents' comfort and energy use. In order to meet the challenges of greater electricity demand in the residential sector, this notion of DR is being extended to smart appliances to let consumers manage their energy use better. For the

\footnotetext{
${ }^{1}$ There are many formal definitions of DR. In general, DR involves a temporary change in electricity use from normal patterns in response to changing electricity prices or other incentives designed to induce such a change during periods of peak consumption or when power grid stability and reliability are threatened.
} 
purpose of this report, a "smart appliance" is defined ${ }^{2}$ as follows:

The term "smart appliance" means a product that uses electricity for its main power source which has the capability to receive, interpret and act on a signal received from a utility, third party energy service provider or home energy management device, and automatically adjust its operation depending on both the signal's contents and settings from the consumer. The product will be sold with this capability, which can be built-in or added through an external device that easily connects to the appliance. The costs of such devices shall be included in the product purchase price. ${ }^{3}$

These signals must include (but are not limited to) appliance delay load, time-based pricing and notifications for load-shedding to meet spinning reserve requirements. Any appliance operation settings or modes shall be easy for an average, non-technical consumer to activate or implement. Additionally, a smart appliance or added device may or may not have the capability to provide alerts and information to consumers via either visual or audible means. The appliance may not be shipped with pre-set time duration limits that are less than those listed below, but may allow consumer-set time duration limits on smart operating modes, and will also allow consumers to override any specific mode (e.g. override a delay to allow immediate operation, limit delays to no more than a certain number of hours, or maintain a set room temperature).

Furthermore, as per the petitioners, smart appliance must have the following attributes

The term “delay load capability" refers to the capability of an appliance to respond to a signal that demands a response intended to meet peak load deferral requirements, but which also could be used to respond to a sudden maintenance issue at another time of day.

The term "spinning reserve capability" means the capability of an appliance to respond to a signal that demands a response intended to temporarily reduce load by a short-term, specified amount, usually 10 minutes. (smart appliances and spinning reserves is taken up in the next section).

In the near future, when smart appliances, along with other smart grid infrastructure (advanced metering infrastructure (AMI), availability of low-cost embedded computing hardware, along with twoway secure communication networks across utility service territories and within customer premises, etc.) are all deployed and appropriate business models and customer incentive structures are in place, the following scenario will be commonplace: when an electric utility company or third-party energy service provider needs to curtail demand, an appropriate signal can be sent to smart appliances at a customer's home, and the appliances are then automated based on customer's preferences to react by possibly

\footnotetext{
${ }^{2}$ This definition of a smart appliance has been proposed by the joint stakeholders in their petition to the EPA. The petition also includes specific definitions by product.

${ }^{3}$ If additional requirements are needed to activate the product's "smart" capabilities as purchased, then prominent labels and instructions must be displayed at the point of purchase and in product literature on what specifically consumers or utilities need to do to achieve these capabilities (e.g. "This product requires snapping in the compatible network module and utility installation of a smart meter or other device for use of capabilities that earned the ENERGY STAR label").
} 
reducing load during this critical time period. Such a reduction can be accomplished by either "shifting" usage to a non-critical time of the day as notified so through another signal, or the smart appliance can "shed" load temporarily thereby reducing peak power usage. According the Federal Energy Regulatory Commission (FERC), the largest gains in reducing peak demand are through full DR participation in the residential sector as shown in Figure 1.2 below

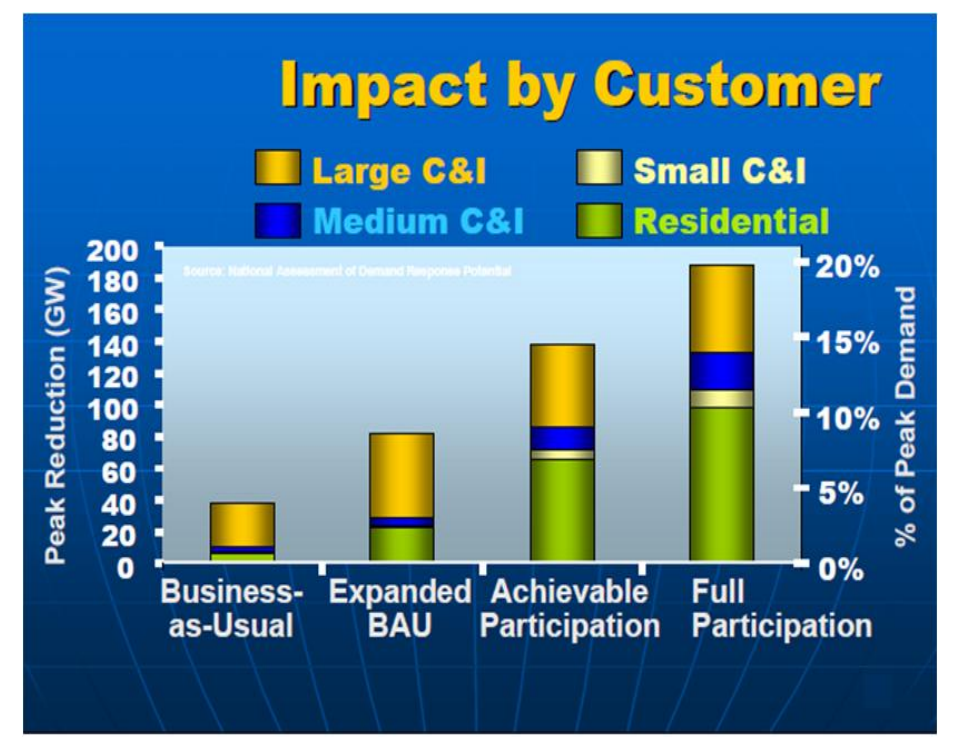

Figure 1.2. FERC's Assessment of DR Potential (FERC 2009)

\subsection{Smart Grid, Smart Appliances, and Increased Penetration of Renewables}

In recent years, due to environmental concerns, there have been increasing efforts around the world to incorporate large amounts of renewable sources of energy, such as solar and wind, and diminish the reliance on fossil fuels to create a more diversified energy supply portfolio. For example, DOE has initiated a collaborative effort to explore the possibility of wind power supplying 20 percent of US electricity needs by the year 2030 (DOE 2010c).

One of the key challenges involved with solar and wind as sources of energy is that they are intermittent and cannot be relied upon with certainty. Solar energy output can drop very quickly with passing clouds, while wind energy output changes very frequently, almost every hour. As a result, in order to balance supply and demand, a key objective of power system operation, it is necessary to maintain energy reserves based on conventional generation sources such as natural gas. But doing so defeats the very purpose of incorporating solar and wind energy, namely, decreasing reliance on fossil fuels.

Just as DR through smart appliances is being considered for managing peak electricity demand, considerable efforts have been undertaken to demonstrate the enormous potential of smart appliances (Eto et al. 2007, Kirby and Kueck 2003, Kirby 2003, Kueck et al 2008) to provide crucial reserves that are 
required to balance supply and demand to support reliable power system operation; this is even more the case with increased penetration of renewables as noted above. Smart appliances are particularly well suited for a class of reserves referred to as "spinning reserves," 4 because the operation of spinning reserves can be interrupted for short periods in response to a curtailment request without causing any diminution in the quality of service to consumers. Thus, instead of ramping generators up and down to provide reserves for balancing services, smart appliances can manage demand to serve the same purpose. Furthermore, end-use loads can often be curtailed almost instantaneously, in contrast with generators, which must ramp up and down subject to operating constraints in order to avoid equipment damage. Finally, given the potentially large number of responsive end loads, their aggregate response could be extremely reliable when called upon to provide reserves. Thus, smart appliances could obviate the need for maintaining fossil-fuel based generation for providing reserves, thereby reducing operating costs and also lowering emissions.

In this work, we undertake a cost/benefit analysis of residential smart appliances from a utility/grid perspective in support of a joint stakeholder petition to the Environmental Protection Agency (EPA) and Department of Energy (DOE). Specifically, we evaluate what the savings in grid operating costs would be if smart appliances deferred their operation from hours of peak operation to off-peak hours, and also served as replacements for spinning reserves. The goal of the petition is to provide appliance manufacturers a financial incentive to hasten the production of smart appliances. The appliances we consider include refrigerator/freezers, clothes washers, clothes dryers, room air conditioners, and dishwashers. Specifically, the petition calls for a five percent credit to the current energy performance level required to meet ENERGY STAR eligibility criteria for products that meet the definition of a smart appliance.

In Section 2.0, we present a general discussion of power system balancing requirements with special emphasis on spinning reserves. Then in Section 3.0, we present our cost/benefit analysis methodology (model), including discussions on the assumptions we make and the use of historical market prices in our analysis. Based on this model, we present benefit-to-cost ratios of various smart appliances in Section 4.0, and finally Section 5.0 summarizes our conclusions.

\footnotetext{
${ }^{4}$ Spinning reserves are part of what are referred to as contingency reserves that are invoked in response to a sudden disturbance such as failure of a generator or transmission line causing a temporary imbalance between supply and demand. A formal description of spinning reserves is given in Section 2.0.
} 


\subsection{Power System Reserve Requirements}

One of the key requirements that must be addressed by power system operators in order to sustain reliable operations is the need to maintain a continuous balance between generation and load at all times. Balancing generation and load instantaneously and continuously is challenging because loads and generators are constantly fluctuating, both predictably and unpredictably. As was alluded to in Section 1.2 , variability of generation is especially acute with integration of large amounts of intermittent renewable sources such as wind and solar. Minute-to-minute load variability is caused by the random turning on and off of millions of individual loads. Longer-term variability arises from predictable factors such as the daily and seasonal patterns of load and weather. Unpredictable variability results from a sudden loss of generators or other equipment, loss of a transmission line, etc. Balancing services in a power system that help overcome these fluctuations and maintain supply/demand balance are referred to as "ancillary services."

There are many types of ancillary services, distinguished from each other based on the time frames over which they are invoked and deployed. The North American Electricity Reliability Corporation (NERC) sets forth standards and rules that power producers are expected to follow regarding the deployment of ancillary services. For example, services needed to correct for fluctuations in the minuteto-minute system load and generator output are referred to as "regulation" and "load following" services (NERC 2002). Over and above these, balancing services over longer time frames include spinning reserves, which are a subset of what are referred to as "contingency reserves" needed to compensate for the worst credible disturbance (WECC 2006). Since our focus in this report is on utilizing smart appliances in place of generators for providing spinning reserves, a brief discussion of spinning reserves is presented next.

\subsection{Spinning Reserves}

To continuously balance supply and demand despite sudden, unexpected failures of generators and/or transmission lines, utilities are expected to maintain what are referred to as contingency reserves to compensate for such failures and restore the generation and load balance in the aftermath of a disturbance or contingency. Typically, the amount of contingency reserves that are maintained is equal to the size of the largest credible disturbance that could occur. For example, the Electric Reliability Council of Texas (ERCOT) maintains enough contingency to guard against the simultaneous loss of two nuclear units.

Contingency reserves further consist of spinning reserves, non-spinning reserves, and replacement reserves. The distinguishing features among these contingency reserve constituents are the time scales over which they are required to be deployed. Spinning reserves are those that can be activated quickly in response to a contingency signal from an ISO/RTO, while non-spinning reserves respond to slower changes. Spinning reserves are typically provided by generators supplying base-load power by operating them below their rated capacity, and then ramping them up when called upon by an ISO/RTO to actually release that unused capacity. In other words, spinning reserves are supplied through unused capacity synchronized with the grid; for this reason, spinning reserves are also called synchronized reserves. Nonspinning reserves are inactive generators that can start up within a short period of time. After a certain period over which spinning and non-spinning reserves are deployed, replacement reserves or other generators (selected based on market bids) are deployed; eventually all the reserves are restored back their pre-contingency levels. 
NERC and the Western Electricity Coordinating Council (WECC) have set forth rules on the amount of contingency reserves that power producers must maintain, and the duration over which they must be deployed should they be called upon by an ISO/RTO in the event of a contingency. The exact proportion of spinning, non-spinning, and replacement reserves, and the durations over which they are deployed, vary from region to region and market to market, but they all operate under the following general rules (NERC 2005, WECC 2006):

1. Spinning reserves must be deployed within 10 minutes after receiving a notification signal from an ISO/RTO. Once deployed, the local grid conditions, such as system frequency, must be restored to pre-contingency values within 15 minutes, referred to as the disturbance recovery period.

2. Following an event or disturbance requiring the activation of contingency reserves, all the contingency reserves must be restored to their pre-contingency levels within 105 minutes (NERC rules) or 75 minutes (WECC rules); this includes a 15-minute disturbance recovery period, plus 90 minutes (NERC) or 60 minutes (WECC).

When called upon, spinning reserves, non-spinning reserves, and replacement reserves operate in coordinated fashion as shown below in Figure 2.1.

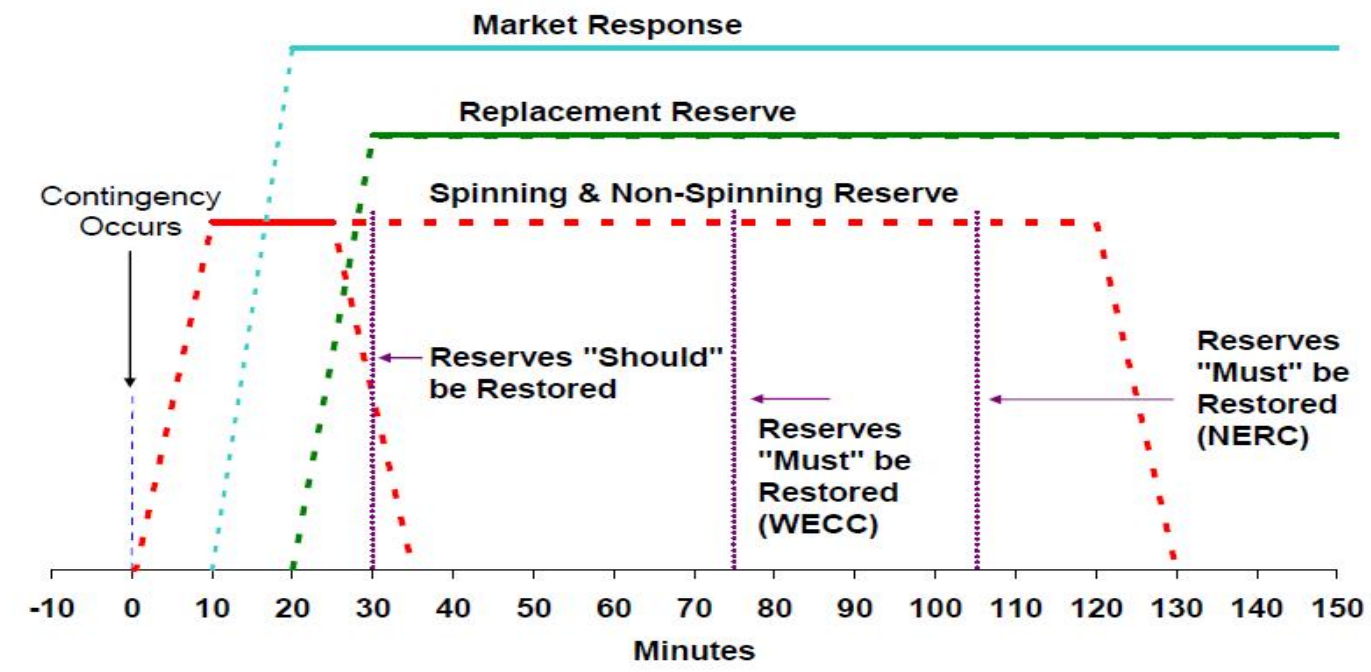

Figure 2.1. Deployment of Contingency Reserves in Response to Sudden Loss of Generator or Transmission Line (Source: Kueck et al 2008)

\subsection{Smart Appliances as Sources of Spinning Reserves}

In the previous section, we alluded to the fact that limits on deployment duration of spinning reserves vary from region to region and market to market. Historical data from three major ISOs indicate that spinning reserves are deployed most often for about 10 minutes or less (Eto et al. 2007). In fact,

ISOs/RTOs usually would like to restore contingency reserves as quickly as possible, well before the 105minute limit set by NERC or the 75-minute limit set by WECC, and actual reserve deployment for long durations is extremely rare as shown in Figure 2.2 below. 


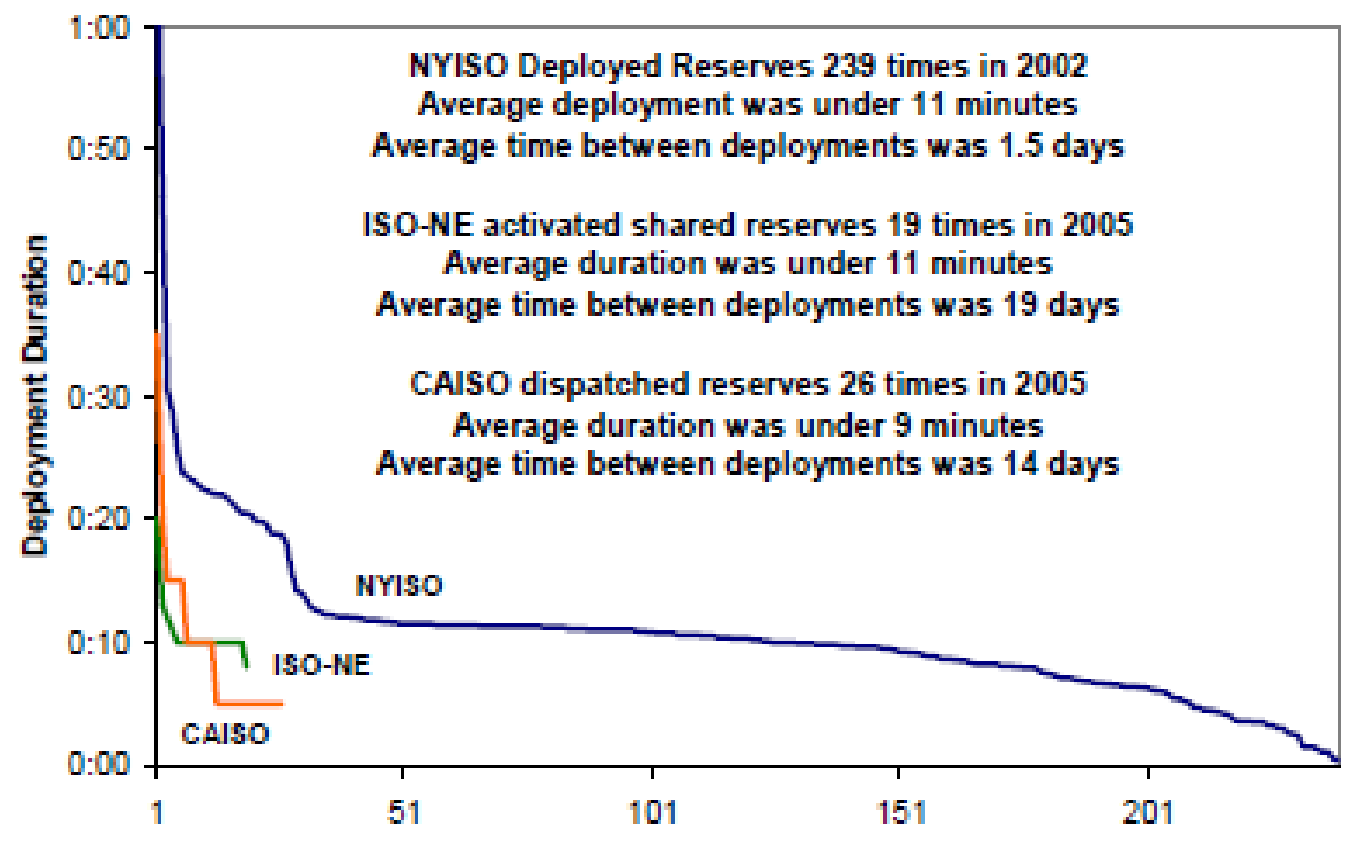

Figure 2.2. Number of Reserve Deployments versus their Duration. (Source: Kueck et al 2008)

In lieu of the extremely short deployment duration of spinning reserves, it has been postulated (ORNL/TM-2003/99) that instead of generators supplying spinning reserves, residential loads deployed in the form of smart appliances (see definition of smart appliance given in Section 1.1) serve as sources of spinning reserves; The rationale is that their operation can be interrupted for short periods (up to 10 minutes) in response to a signal from a utility or third-party energy service provider without causing any diminution in the quality of service for consumers. Furthermore, appliance loads can often be curtailed almost instantaneously, in contrast with generators, which must restart, ramp up and down subject to operating constraints in order to avoid equipment damage. Moreover increased emissions can result due to the inefficiencies inherent in restarting and ramping up generation (Wellinghoff et al. 2008). Finally, given the potentially large number of residential loads that are available in any service territory, their aggregate response could be extremely reliable when called upon to provide spinning reserves (In most regions of the U.S., the required spinning reserve capacity amounts to 5 percent of demand or more).

Thus, residential loads deployed in the form of smart appliances could obviate the need for maintaining some fossil-fuel based generation for providing spinning reserves, thereby reducing operating costs and also lowering emissions. There is also an extensive body of work that demonstrates this potential of smart appliances as sources of spinning reserves (Eto et al 2007, Kirby and Kueck 2003, Kueck et al 2008). 



\subsection{Smart Appliance Cost/Benefit Analysis Model}

In this section we present our smart-appliance cost/benefit model that will be used in later sections to calculate the costs and benefits for each appliance. First, in Section 3.1, we present key user-definable assumptions and appliance data that would be required for the analysis. We present both the "optimistic" and "pessimistic" sets of assumptions leading to best-case and low-end benefits respectively. In Section 3.2, we present historical wholesale market prices that we would utilize to estimate costs and benefits. Then in Section 3.3, we present appliance load shapes, i.e., electricity consumption of each appliance over each hour of an average day, and finally in Section 3.4, we present the methodology we use to estimate costs and benefits of smart appliances.

\subsection{Assumptions}

In this section, we present the set of input assumptions and other raw data on which calculations of the benefits and costs are based.

\subsubsection{On-Peak Hours}

A key input to our analysis framework is the notion of "on-peak" hours on any day. These are those hours when consumption for electricity peaks relative to that during the rest of the day. Shown in Table 3.1 and Table 3.2 are optimistic and pessimistic definitions of on-peak hours, respectively, for all appliances except RACs. Note the difference. In the optimistic view, on-peak hours start at noon and continue until 6 p.m., and they occur on all days of a week. In the pessimistic view, on-peak hours start at 1 p.m. and continue until 5 p.m., and they occur only on weekdays.

Table 3-1. On-Peak, Off-Peak, and Hours to Which the Load is Shifted for all Appliances except RACs Optimistic View

\begin{tabular}{|c|c|c|c|c|c|}
\hline & \multicolumn{3}{|c|}{ On-Peak Defintion } & \multicolumn{2}{c|}{$\begin{array}{c}\text { Shift Load } \\
\text { To Hours }\end{array}$} \\
\cline { 2 - 5 } & Hour & Months & $\begin{array}{c}\text { Weekday } \\
\text { (Mon=1) }\end{array}$ & 18 & 0 \\
\hline Start At & 12 & 1 & 1 & 23 & 11 \\
\hline Through & 17 & 12 & 7 & & \\
\hline
\end{tabular}


Table 3-2. On-Peak, Off-Peak, and Hours to Which the Load is Shifted for all Appliances except RACs Pessimistic View

\begin{tabular}{|c|c|c|c|c|c|}
\hline & \multicolumn{3}{|c|}{ On-Peak Defintion } & \multirow{2}{*}{\multicolumn{2}{|c|}{$\begin{array}{c}\text { Shift Load } \\
\text { To Hours }\end{array}$}} \\
\hline & Hour & Months & Weekday & & \\
\hline Start At & 13 & 1 & 1 & 17 & 0 \\
\hline Through & 16 & 12 & 5 & 23 & 12 \\
\hline
\end{tabular}

In Table 3.1 and Table 3.2, the "Shift Load To Hours" lets user specify the hours to which peak load can be shifted; they need not be all of the off-peak hours, only some sub set of them (In Table 3.1 and Table 3.2, they happen to be the same as off-peak hours). The two columns allow for the possibility that "shift-to" hours can cross midnight: for example, in Table 3-1, peak load is shifted to run anywhere between Hour18 and midnight, or from midnight up to 11 a.m. the next day.

RAC consumption occurs only during the summer months, and in all other months, there is no RAC consumption. Table 3.3 and Table 3.4 are optimistic and pessimistic definitions of on-peak hours for RACs. Note that in both cases, on-peak hours for RACs occur only during the months June through September.

Table 3-3. On-Peak, Off-Peak, and Hours to Which the Load is Shifted for RACs - Optimistic View

\begin{tabular}{|c|c|c|c|c|c|}
\hline & \multicolumn{3}{|c|}{ On-Peak Defintion } & \multicolumn{2}{|c|}{$\begin{array}{c}\text { Shift Load } \\
\text { To Hours }\end{array}$} \\
\cline { 2 - 6 } & Hour & Months & $\begin{array}{c}\text { Weekday } \\
\text { (Mon=1) }\end{array}$ & 18 & 0 \\
\hline Start At & 12 & 6 & 1 & 23 & 11 \\
\hline
\end{tabular}

Table 3-4. On-Peak, Off-Peak, and Hours to Which the Load is Shifted for RACs - Pessimistic View

\begin{tabular}{|c|c|c|c|c|c|}
\hline & \multicolumn{3}{|c|}{ On-Peak Defintion } & \multicolumn{2}{|c|}{$\begin{array}{c}\text { Shift Load } \\
\text { To Hours }\end{array}$} \\
\cline { 2 - 5 } & Hour & Months & $\begin{array}{c}\text { Weekday } \\
\text { (Mon=1) }\end{array}$ & 17 & 0 \\
\hline Start At & 13 & 6 & 1 & 23 & 12 \\
\hline Through & 16 & 9 & 5 & &
\end{tabular}

Given months (Months/Year) and days of week (Days/Week) during which on-peak hours occur as shown in Table 3.1 through Table 3.4, the numbers of days in the year during which those on-peak hours occur, Days/Year, can be calculated as follows:

$$
\text { Days } / \text { Year }=[365 *(\text { Months } / \text { Year }) / 12] *[(\text { Days/Week }) / 7]
$$




\subsubsection{Annual Electricity Consumption}

Annual electricity consumption, presented below for each appliance, is another key data input to our cost/benefit analysis model. This data was provided to us by AHAM (AHAM 2009), and is also based on DOE appliances \& commercial equipment standards (DOE 2010a).

\subsubsection{Annual Electricity Consumption: Clothes Dryer (CD)}

The annual CD electricity consumption data is presented below:

$$
\begin{array}{ll}
\text { Energy factor }(\mathrm{EF}) \text { for standard electric CD } & =3.01 \mathrm{lbs} / \mathrm{kWh} / \text { cycle } \\
\text { DOE standard sized CD load } & =7 \mathrm{lbs} \\
\text { CD electricity consumption per cycle } & =\text { DOE standard sized dryer load }(7 \mathrm{lbs}) \div \\
\quad \text { EF }(3.01 \mathrm{lbs} / \mathrm{kWh} / \text { cycles }) & =2.33 \mathrm{kWh} / \text { cycle } \\
\text { CD cycles/year (latest DOE proposal } \left.{ }^{1}\right) & =283 \mathrm{cycles} / \text { year } \\
\text { CD electricity consumption/year } & =2.33 \mathrm{kWh} / \text { cycle } * 283 \text { cycles } / \text { year }=658 \mathrm{kWh} / \text { year }
\end{array}
$$

\subsubsection{Annual Electricity Consumption: Room Air Conditioner (RAC)}

RAC electricity consumption data below is presented below:
RAC annual usage
$=750$ hours
RAC electricity consumption /year $=693 \mathrm{kWh} /$ year

\subsubsection{Annual Electricity Consumption: Freezer}

Freezer electricity consumption data is presented below:

Freezer electricity consumption /year $=423 \mathrm{kWh} /$ year

\subsubsection{Annual Electricity Consumption: Refrigerator}

The refrigerator electricity consumption data is presented below:

There are three main factors that contribute to a refrigerator's annual electricity consumption: the first is the consumption needed to keep refrigerator's contents at a certain temperature; the second is the electricity required for making ice. And finally, the electricity consumed for periodic defrosting. We present all three parts below.

Total refrigerator electricity consumption $/$ year $=450 \mathrm{kWh} /$ year

Average coefficient of performance (COP) of compressor $=1.5$

\footnotetext{
${ }^{1}$ Current DOE standard $=416$ cycles $/$ year
} 
Heat electricity consumption for defrost/day $=500 \mathrm{~W}$ for 10 minutes per day $=0.083 \mathrm{kWh} /$ day Post-defrost cool-down electricity consumption/day ${ }^{2}=0.083 \mathrm{kWh} /$ day $\div \mathrm{COP}=0.05 \mathrm{kWh} /$ day Electricity consumption for defrost $/$ year $=(0.083+0.05) \mathrm{kWh} /$ day $* 365$ days $/$ year $=50.7 \mathrm{kWh} /$ year $^{3}$ Ice-making electricity consumption/day $\quad=0.23 \mathrm{kWh} /$ day (at $1.8 \mathrm{lbs}$ of ice/day) Ice-making electricity consumption/year $\quad=0.23 \mathrm{kWh} /$ day $* 365$ days $/$ year $=84 \mathrm{kWh} /$ year $^{4}$

\subsubsection{Annual Electricity Consumption: Clothes Washer (CW)}

CWs present some unique challenges for the following reasons. CWs use hot water from the residence water heater during the wash cycle. So, the first issue is that overall electricity consumption by a CW must be split between $\mathrm{CW}$ machine consumption, and $\mathrm{CW}$ water-heater consumption.

Furthermore, not all residential water heaters use electricity for their operation - many residential water heaters are gas-fired. Both these issues are taken into account in estimating $\mathrm{CW}$ electricity consumption.

Energy consumption per CW cycle

CW cycles/year (latest DOE proposal ${ }^{5}$ )

$\mathrm{CW}$ energy consumption /year
$=0.71 \mathrm{kWh} /$ cycle

$=295$ Cycles/year $=0.71 \mathrm{kWh} /$ cycle $* 295=209 \mathrm{kWh} /$ year
cycles $/$ year

$\mathrm{CW}$ machine energy (electricity) consumption $/$ year $=\begin{aligned} & 50 \% \text { of } \mathrm{CW} \text { energy } \\ & \text { consumption } / \text { year }^{6}\end{aligned} \quad=105 \mathrm{kWh} /$ year

CW hot water energy (electricity + gas)

consumption /year

$=\begin{aligned} & 50 \% \text { of } \mathrm{CW} \text { energy } \\ & \text { consumption /year }\end{aligned} \quad=105 \mathrm{kWh} /$ year

In order to estimate percentage of CWs that are supplied from gas-fired water heaters, we use data from DOE (EERE 2009).

Total residential energy consumption for water heating $\quad=1.67$ Quadrillion Btu

Total electricity consumption for residential water $\quad=0.42$ Quadrillion Btu heating

Residential water-heating electricity usage fraction $\quad=0.42 \div 1.67 \quad=25 \%$

\footnotetext{
${ }^{2}$ After defrost, compressor must run longer. If $10 \mathrm{BTU}$ of heat is added as a result of defrost, then compressor needs to consume electricity to remove those 10 BTUs.

${ }^{3}$ Defrost energy consumption of $50.7 \mathrm{kWh} /$ year amounts to $11 \%$ of $450 \mathrm{kWh} /$ year (total annual refrigerator energy consumption/year).

${ }^{4}$ Ice-making energy consumption of $84 \mathrm{kWh} /$ year amounts to $18.7 \%$ of $450 \mathrm{kWh} /$ year (total annual refrigerator energy consumption/year).

${ }^{5}$ Current DOE standard $=392$ cycles/year

${ }^{6}$ The split of total CW annual energy use between machine use and hot water energy use was supplied by AHAM.
} 


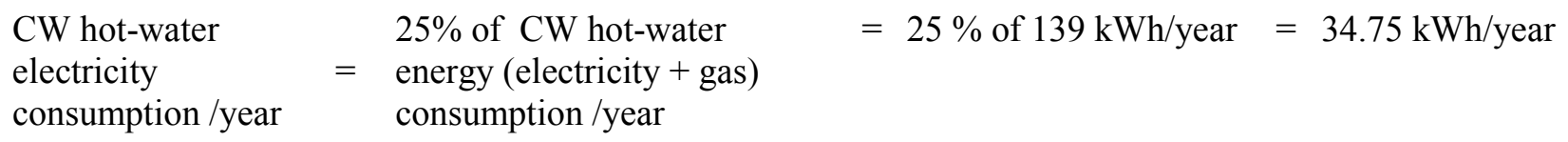

\subsubsection{Annual Electricity Consumption: Dishwasher (DW)}

The dishwasher electricity consumption data presented below is split between usage by the dishwasher and water heating as was done for CWs above:

\begin{tabular}{|c|c|c|}
\hline Energy consumption per DW cycle & $=1.45 \mathrm{kWh} /$ cycle & \\
\hline DW cycles/year & $=215$ Cycles/year & \\
\hline DW energy consumption/year & $\begin{aligned}= & 1.45 \mathrm{kWh} / \text { cycle } * 215 \\
& \text { cycles } / \text { year }\end{aligned}$ & $=312 \mathrm{kWh} /$ yer \\
\hline DW machine energy (electricity) consumption /year & $=\begin{array}{l}50 \% \text { of DW energy } \\
\text { consumption } / \text { year }\end{array}$ & $=156 \mathrm{kWh} /$ yea \\
\hline $\begin{array}{l}\mathrm{CW} \text { hot water energy (electricity }+ \text { gas) } \\
\text { consumption /year }\end{array}$ & $=\begin{array}{l}50 \% \text { of } \mathrm{CW} \text { energy } \\
\text { consumption /year }\end{array}$ & $=156 \mathrm{kWh} / \mathrm{ye}$ \\
\hline nally, & & \\
\hline $\begin{array}{l}\begin{array}{l}\text { DW hot-water } \\
\text { electricity } \\
\text { consumption /year }\end{array} \quad \begin{array}{l}25 \% \text { of DW hot-water } \\
\text { energy (electricity }+ \text { gas) } \\
\text { consumption /year }\end{array}\end{array}$ & $=25 \%$ of $156 \mathrm{kWh} /$ year & $=39 \mathrm{kWh} /$ year \\
\hline
\end{tabular}

\subsubsection{Peak Load-Shift Fraction}

The benefits of each smart appliance depend on how much appliance load is actually available for peak-load shifting. "Appliance load" refers to total electricity consumption, and during peak periods all of this load or part of it can be shifted. In the case of refrigerators/freezers, appliance load refers to defrost load or ice-making load, and it is these loads that are available for shifting during peak periods. In the case of CWs and DWs, we have machine-only consumption, and water-heater consumption. Recall, CWs and DWs use hot water from installed residential water heaters for their operation. And furthermore, not all residential water heaters are electricity powered, many are gas-fired (see Sections 3.1.2.5 and 3.1.2.6). We consider all these splits in estimating the CW and DW electricity load available for shifting away from peak hours.

Peak load-shift fraction determines the amount of appliance load that is shifted from peak hours to "shift-to" hours. (Recall the definition of on-peak and "shift to" hours described in Section 3.1.1). Formally, we refer to this fraction as "Net Fraction of On-Peak Load Available to Shift". This is the product of three other fractions:

1. "Fraction of Customers Receiving Grid Signals and Communicating These to an Appliance", i.e. those consumers who have the capability to receive pricing and other grid signals from a utility or 
third-party energy service providers and passing them on to an appliance to manage its consumption. These signals could be received through a smart meter as part of smart grid advanced metering infrastructure (AMI), or through some other interface into the home. And the signals can reach the smart appliances either directly or through some intermediary mechanism such as a home gateway or what AHAM refers to as a "hub" (AHAM 2010).

2. Of those customers who have the capability described in \#1, some will override, and the remaining will be willing to shift load; these we define as "Fraction of Customers Willing to Shift On-Peak Load".

3. Finally, among those customers who do not override and are willing to shift peak load as in \#2, some may not be willing to shift their entire on-peak load. This is captured through "Fraction of On-Peak Load that Willing Customers Shift".

Shown in Table 3.5 are the various best-case "optimistic" and worst-case "pessimistic" assumptions for the above three fractions for all appliances except refrigerators and freezers. Also shown is the bestcase and worst-case "Net Fraction of On-Peak Load Available to Shift" computed based on these fractions.

In the case of freezers and refrigerators, the on-peak loads are split into their defrost and ice-making components as shown in Table 3.6.

Table 3-5. Net Fraction of On-Peak Load Available to Shift for all Appliances Except Freezers and Refrigerators

\begin{tabular}{|r|c|c|c|c|c|c|c|c|}
\hline & $\begin{array}{c}\text { Fraction of Customers } \\
\text { Receiving Grid Signals and } \\
\text { Communicating These to } \\
\text { an Appliance }\end{array}$ & $\begin{array}{c}\text { Fraction of Customers } \\
\text { Willing to Shift On-Peak } \\
\text { Load }\end{array}$ & $\begin{array}{c}\text { Fraction of On-Peak } \\
\text { Load that Willing } \\
\text { Customers Shift }\end{array}$ & $\begin{array}{c}\text { Net Fraction of On- } \\
\text { Peak Load Available to } \\
\text { Shift }\end{array}$ \\
\cline { 2 - 9 } Appliance & Optimistic & Pessimistic & Optimistic & Pessimistic & Optimistic & Pessimistic & Optimistic & Pessimistic \\
\hline Clothes Dryer & $100 \%$ & $50 \%$ & $100 \%$ & $70 \%$ & $100 \%$ & $50 \%$ & $100 \%$ & $18 \%$ \\
\hline Clothes Washer & $100 \%$ & $50 \%$ & $100 \%$ & $70 \%$ & $100 \%$ & $50 \%$ & $100 \%$ & $18 \%$ \\
\hline DishWasher & $100 \%$ & $50 \%$ & $100 \%$ & $70 \%$ & $100 \%$ & $70 \%$ & $100 \%$ & $25 \%$ \\
\hline Room Air Conditioner & $100 \%$ & $50 \%$ & $100 \%$ & $50 \%$ & $100 \%$ & $25 \%$ & $100 \%$ & $6 \%$ \\
\hline
\end{tabular}

Table 3-6. Net Fraction of Freezer and Refrigerator On-Peak Defrost and Ice-Making Loads Available to Shift

\begin{tabular}{|c|c|c|c|c|c|c|c|c|c|c|c|c|c|c|}
\hline \multirow[b]{2}{*}{ Appliance } & \multicolumn{2}{|c|}{$\begin{array}{c}\text { Fraction of Customers } \\
\text { Receiving Grid Signals and } \\
\text { Communicating These to } \\
\text { an Appliance } \\
\end{array}$} & \multicolumn{2}{|c|}{$\begin{array}{c}\text { Fraction of Customers } \\
\text { Willing to Shift On-Peak } \\
\text { Defrost Load }\end{array}$} & \multicolumn{2}{|c|}{$\begin{array}{c}\text { Fraction of On-Peak } \\
\text { Defrost Load that } \\
\text { Willing Customers } \\
\text { Shift } \\
\end{array}$} & \multicolumn{2}{|c|}{$\begin{array}{l}\text { Net Fraction of On- } \\
\text { Peak Defrost Load } \\
\text { Available to Shift }\end{array}$} & \multicolumn{2}{|c|}{$\begin{array}{l}\text { Fraction of Customers } \\
\text { Willing to Shift On-Peak } \\
\text { Ice-Making Load }\end{array}$} & \multicolumn{2}{|c|}{$\begin{array}{c}\text { Fraction of On-Peak Ice- } \\
\text { Making Load that } \\
\text { Willing Customers Shift }\end{array}$} & \multicolumn{2}{|c|}{$\begin{array}{l}\text { Net Fraction of On-Peak } \\
\text { Ice-Making Load } \\
\text { Available to Shift }\end{array}$} \\
\hline & Optimistic & Pessimistic & Optimistic & Pessimistic & Optimistic & Pessimistic & Optimistic & Pessimistic & Optimistic & Pessimistic & Optimistic & Pessimistic & Optimistic & Pessimistic \\
\hline Freezer & $100 \%$ & $50 \%$ & $100 \%$ & $90 \%$ & $100 \%$ & $100 \%$ & $100 \%$ & $45 \%$ & $100 \%$ & $90 \%$ & $100 \%$ & $60 \%$ & $100 \%$ & $27 \%$ \\
\hline Refrigerator & $100 \%$ & $50 \%$ & $100 \%$ & $90 \%$ & $100 \%$ & $100 \%$ & $100 \%$ & $45 \%$ & $100 \%$ & $90 \%$ & $100 \%$ & $60 \%$ & $100 \%$ & $27 \%$ \\
\hline
\end{tabular}

\subsubsection{Load Fraction Available for Spinning Reserves}

The benefits of each smart appliance depend on how much appliance load is actually available for spinning reserves (and as we will see later, the spinning reserve benefits far outweigh the peak-load 
shifting benefits). Similar to "Net Fraction of On-Peak Load Available to Shift," we also define "Net Fraction of Load Available for Spinning Reserves" with the caveat that appliance load is available for spinning reserves all the time. In other words, anytime appliances are operating, they can be interrupted for a short duration, up to 10 minutes or so, either by shutting off or reducing their electricity consumption in response to a spinning-reserve request signal (for example, a dryer operating with two heating elements might continue to operate but with only one heating element on). The "Net Fraction of Load Available for Spinning Reserves" is a product of three other fractions:

4. "Fraction of Customers Receiving Grid Signals and Communicating these to an Appliance" as described above.

5. Of those customers who have the capability described in \#1, only some of them will be willing to make their appliances available for spinning reserves; these we define as "Fraction of Customers Willing to Provide Spinning Reserves."

6. Finally, among those customers who do not override a request for spinning reserves as in $\# 2$, they may not be willing to make their entire load available for spinning reserves even for a short duration. This is captured through "Fraction of Appliance Load Reduced for Spinning Reserves."

Shown in Table 3.7 is the "Net Fraction of Load Available for Spinning Reserves" for all appliances, based on various best-case "optimistic" and worst-case "pessimistic" assumptions for the above three fractions.

Table 3-7. Net Fraction of Load Available for Spinning Reserves Available for all Appliances

\begin{tabular}{|r|c|c|c|c|c|c|c|c|}
\hline & \multicolumn{2}{|c|}{$\begin{array}{c}\text { Fraction of Customers } \\
\text { Receiving Grid Signals and } \\
\text { Communicating These to } \\
\text { an Appliance }\end{array}$} & $\begin{array}{c}\text { Fraction of Customers } \\
\text { Willing to Provide } \\
\text { Spinning Reserves }\end{array}$ & $\begin{array}{c}\text { Fraction of Appliance } \\
\text { Load Reduced for } \\
\text { Spinning Reserves }\end{array}$ & $\begin{array}{c}\text { Net Fraction of Load } \\
\text { Available for Spinning } \\
\text { Reserves }\end{array}$ \\
\cline { 2 - 9 } Appliance & Optimistic & Pessimistic & Optimistic & Pessimistic & Optimistic & Pessimistic & Optimistic & Pessimistic \\
\hline Clothes Dryer & $100 \%$ & $50 \%$ & $100 \%$ & $90 \%$ & $100 \%$ & $80 \%$ & $100 \%$ & $36 \%$ \\
\hline Clothes Washer & $100 \%$ & $50 \%$ & $100 \%$ & $90 \%$ & $100 \%$ & $50 \%$ & $100 \%$ & $23 \%$ \\
\hline DishWasher & $100 \%$ & $50 \%$ & $100 \%$ & $90 \%$ & $100 \%$ & $50 \%$ & $100 \%$ & $23 \%$ \\
\hline Room Air Conditioner & $100 \%$ & $50 \%$ & $100 \%$ & $90 \%$ & $100 \%$ & $80 \%$ & $100 \%$ & $36 \%$ \\
\hline Freezer & $100 \%$ & $50 \%$ & $100 \%$ & $90 \%$ & $100 \%$ & $50 \%$ & $100 \%$ & $23 \%$ \\
\hline Refrigerator & $100 \%$ & $50 \%$ & $100 \%$ & $90 \%$ & $100 \%$ & $50 \%$ & $100 \%$ & $23 \%$ \\
\hline
\end{tabular}

\subsubsection{Consumer Behavior Feedback Effect}

Many DR projects have reported some customer energy savings, typically a few percentage points, in addition to their primary objective of reducing peak loads. While some energy savings can be attributed to physical effects of reducing load during peak load times, the primary basis for the savings is likely to be the effect of feedback provided to consumers on their usage patterns as part of these programs. Numerous studies examined by Fischer (Fischer 2008, ACEEE 2010) have shown that consumer feedback on their energy consumption habits can result in savings ranging from 5-20 percent, with a 
median of approximately 6 percent. Similar results have been observed in utility field studies reviewed by Faruqui (2009).

The studies reviewed provide convincing evidence that consumers will change their energy consumption behavior in response to feedback, and that the conditions surrounding feedback, such as frequency and specificity, are influential variables. The studies show that feedback tends to be most effective when it:

- is based on actual usage data

- is provided on a frequent basis (daily is better than weekly, etc.)

- involves goal setting and choice

- is provided over a year or more

- involves specific behavioral recommendations regarding appliances

- involves normative or historical comparisons.

Fischer (2008) has noted that these favor the smart grid capabilities offered by AMI and two-way communication networks, which provide an effective way of engaging the consumer continually and providing specific feedback tailored to their individual consumption patterns. This should help sustain savings over a time periods of years and decades.

While some appliances may benefit more than others, it must be emphasized that it is their collective contribution to the richness of the information that enables the value of such specific feedback. In other words, this reduction figure applies to the total home consumption, rather than to each specific appliance's usage. The benefit of the feedback accrues from the information ecosystem that the smart appliances create within the home. A home energy management system that can accurately estimate the consumption of each appliance using signals sent out by the collection of smart appliances may suggest, for example, that

- a new refrigerator that meets current efficiency standards would pay for itself in five years

- washing clothes in warm water instead of hot water would save you $\$ 30$ a year

- a vertical-axis clothes washer with high-speed spin would save you \$35 a year in hot water and \$20 a year in reduced dryer energy

- The air conditioner needs service - it is running twice as much as last year in the same type of weather, and costing $\$ 200$ a year extra.

While there are no studies to estimate what electricity consumption savings would be possible from each appliance as a result of energy-use feedback, we assume that there is an average reduction of 3\% (pessimistic assumption) and 6\% (optimistic assumption) per appliance. 


\subsection{Historical Market Prices}

As mentioned earlier, both the costs involved in the operation of smart appliances and the benefits they provide are estimated in terms of historical wholesale-market data. The historical market data we consider include hourly LMP and spinning-reserve wholesale market-clearing prices over the course of a year (PJM 2006, ERCOT 2008, NYISO 2006, NYISO 2008, CAISO 2008). Based on hourly data over the course of a year, we compute various annual hourly averages for both LMP and spinning-reserve prices (these average prices will then be used later to estimate costs and benefits).

In Section 3.1.1, we presented the notion of on-peak and off-peak hours, and, for RAC, the months during which on-peak hours are expected to occur. We assumed that all appliances except RACs operate during on-peak hours every day throughout the year. Based on this assumption, we compute annual hourly averages for LMP and spinning-reserve market-clearing prices as shown below in Table 3.8.

Table 3-8. Annual Hourly Averages of LMP and Spinning Reserve Wholesale Market Clearing Prices

\begin{tabular}{|c|c|c|c|c|c|c|}
\hline \multirow[b]{3}{*}{ Market } & \multirow{2}{*}{\multicolumn{2}{|c|}{$\begin{array}{c}\text { Annual Average Over } \\
\text { On-Peak Hours } \\
\text { (\$/MWh) }\end{array}$}} & \multirow{2}{*}{\multicolumn{2}{|c|}{$\begin{array}{c}\begin{array}{c}\text { Annual Average Over } \\
\text { Off-Peak Hours }\end{array} \\
\text { (\$/MWh) }\end{array}$}} & \multirow{2}{*}{\multicolumn{2}{|c|}{$\begin{array}{c}\text { Annual Average Over } \\
\text { Shift-To Hours } \\
\text { (\$/MWh) }\end{array}$}} \\
\hline & & & & & & \\
\hline & LMP & SR & LMP & SR & LMP & SR \\
\hline PJM 2006 & 50.64 & 7.29 & 39.44 & 8.08 & 39.44 & 8.08 \\
\hline ERCOT 2008 & 105.56 & 36.85 & 67.09 & 23.76 & 67.09 & 23.76 \\
\hline NYISO 2008 & 115.97 & 14.84 & 92.25 & 8.56 & 92.27 & 8.56 \\
\hline NYISO 2006 & 85.05 & 12.40 & 67.44 & 5.42 & 67.41 & 5.42 \\
\hline CAISO 2008 & 82.11 & 13.26 & 65.01 & 3.56 & 65.02 & 3.57 \\
\hline
\end{tabular}

For estimating the costs and benefits of RACs, we consider average wholesale market-clearing prices only over the months during which peak hours are expected to occur. Recall from Section 3.1.1, our assumption is that RACs operate only for 4 months (summer months: June-September) during the course of a year, and based on this assumption, we compute hourly averages of LMP and spinning-reserve market-clearing prices over those months as shown below in Table 3.9. 
Table 3-9. Hourly Averages of LMP and Spinning-Reserve Wholesale Market-Clearing Prices Over Months June through September

\begin{tabular}{|c|c|c|c|c|c|c|}
\hline \multirow[b]{3}{*}{ Market } & \multirow{2}{*}{\multicolumn{2}{|c|}{$\begin{array}{c}\begin{array}{c}\text { Annual Average Over } \\
\text { On-Peak Hours }\end{array} \\
\text { (\$ / MWh })\end{array}$}} & \multirow{2}{*}{\multicolumn{2}{|c|}{$\begin{array}{c}\begin{array}{c}\text { Annual Average Over } \\
\text { Off-Peak Hours }\end{array} \\
\text { (\$/MWh) }\end{array}$}} & \multirow{2}{*}{\multicolumn{2}{|c|}{$\begin{array}{c}\text { Annual Average Over } \\
\text { Shift-To Hours } \\
\text { (\$/MWh) }\end{array}$}} \\
\hline & & & & & & \\
\hline & LMP & SR & LMP & SR & LMP & SR \\
\hline PJM 2006 & 66.12 & 4.31 & 36.59 & 3.54 & 36.59 & 3.54 \\
\hline ERCOT 2008 & 126.97 & 36.85 & 73.33 & 23.76 & 73.33 & 23.76 \\
\hline NYISO 2008 & 151.26 & 14.84 & 93.35 & 8.56 & 100.09 & 8.56 \\
\hline NYISO 2006 & 115.97 & 12.40 & 64.36 & 5.42 & 64.36 & 5.42 \\
\hline CAISO 2008 & 109.26 & 13.26 & 69.76 & 3.56 & 69.76 & 3.57 \\
\hline
\end{tabular}

The average prices shown above in Table 3.8 will be used later to estimate costs and benefits of RACs, while those shown in Table 3.9 will be used to estimate costs and benefits of all other appliances.

In our discussion of on-peak hours in Section 3.1.1, we presented the notion of "shift-to" hours. In general, the "shift-to" hours could be different from off-peak hours, but in our assumptions from Table 3.1, Table 3.2, Table 3.3, and Table 3.4, we note that "shift-to" hours are in fact all of the off-peak hours. Hence, from Table 3.8 and Table 3.9, we note that average prices over the shift-to hours are the same as those over off-peak hours.

\subsection{Appliance Load Shapes}

In order to estimate what the annual operating expenses would be for each appliance, it is required to get a measure of the average electricity consumption of each appliance over the course of each hour on an average day. This is what is referred to as "appliance load shape." An "average" day could be an average annual day, an average summer day, etc. For the purpose of this report, we utilize the load shapes developed as part of the End-Use Load and Consumer Assessment Program (Pratt et al. 1989). In the sections to follow, we present the load shapes for each appliance.

\subsubsection{Clothes Dryer (CD) Load Shape}

The hourly electricity consumption by a dryer on an average annual day is shown below in Table 3.10 .

Table 3-10. ELCAP CD Hourly Consumption on an Average Annual Day

\begin{tabular}{|c|c|c|c|c|c|c|c|c|c|c|c|c|}
\hline Hour & 1 & 2 & 3 & 4 & 5 & 6 & 7 & 8 & 9 & 10 & 11 & 12 \\
\hline $\mathbf{k W}-\mathrm{hr} / \mathrm{hr}$ & 0.0346 & 0.0149 & 0.0086 & 0.0060 & 0.0067 & 0.0180 & 0.0494 & 0.0907 & 0.1257 & 0.1744 & 0.2083 & 0.2161 \\
\hline Hour & 13 & 14 & 15 & 16 & 17 & 18 & 19 & 20 & 21 & 22 & 23 & 24 \\
\hline $\mathbf{k W}-\mathrm{hr} / \mathrm{hr}$ & 0.2023 & 0.1901 & 0.1720 & 0.1644 & 0.1657 & 0.1666 & 0.1607 & 0.1584 & 0.1657 & 0.1709 & 0.1394 & 0.0810 \\
\hline
\end{tabular}

The CD load shape based on the data shown in Table 3.10 in shown in Figure 3.1 below. 


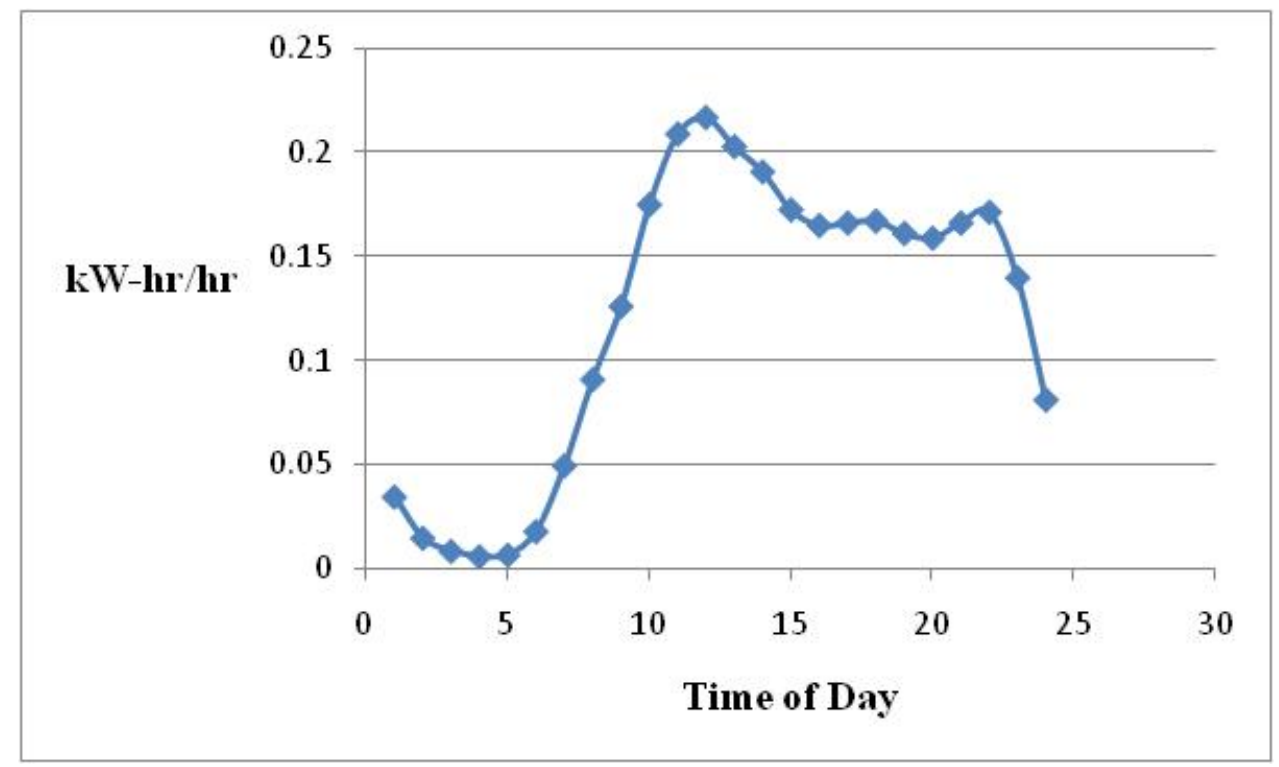

Figure 3.1. ELCAP Dryer Load Shape for an Average Annual Day

\subsubsection{Dishwasher Load Shape}

The hourly electricity consumption by a dishwasher on an average annual day is shown below in Table 3.11.

Table 3-11. ELCAP Dishwasher Hourly Consumption on an Average Annual Day

\begin{tabular}{|c|c|c|c|c|c|c|c|c|c|c|c|c|}
\hline Hour & 1 & 2 & 3 & 4 & 5 & 6 & 7 & 8 & 9 & 10 & 11 & 12 \\
\hline kW-hr/hr & 0.0075 & 0.0034 & 0.0017 & 0.0014 & 0.0012 & 0.0031 & 0.0061 & 0.0111 & 0.0169 & 0.0190 & 0.0177 & 0.0149 \\
\hline Hour & 13 & 14 & 15 & 16 & 17 & 18 & 19 & 20 & 21 & 22 & 23 & 24 \\
\hline kW-hr/hr & 0.0144 & 0.0153 & 0.0132 & 0.0123 & 0.0133 & 0.0159 & 0.0270 & 0.0330 & 0.0276 & 0.0230 & 0.0188 & 0.0135 \\
\hline
\end{tabular}

The dishwasher load shape based on the data shown in Table 3.11 is shown in Figure 3.2 below. 


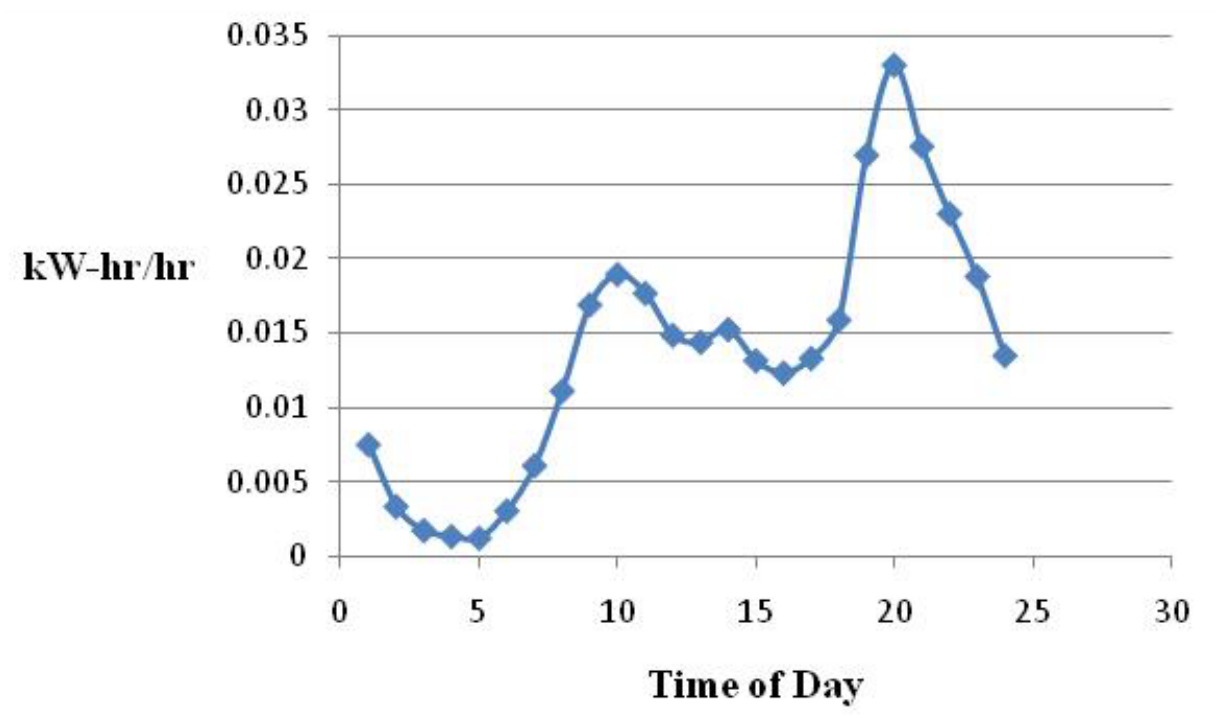

Figure 3.2. ELCAP Dishwasher Load Shape for an Average Annual Day

\subsubsection{RAC Load Shape}

In the case of a RAC, we only consider electricity consumption during the summer months (JuneSeptember). The hourly electricity consumption by a RAC on an average summer day is shown below in Table 3.12

Table 3-12. ELCAP RAC Hourly Consumption on an Average Summer Day

\begin{tabular}{|c|c|c|c|c|c|c|c|c|c|c|c|c|}
\hline Hour & 1 & 2 & 3 & 4 & 5 & 6 & 7 & 8 & 9 & 10 & 11 & 12 \\
\hline kW-hr/hr & 0.1200 & 0.1000 & 0.0900 & 0.0800 & 0.0800 & 0.0900 & 0.1271 & 0.1600 & 0.1757 & 0.1929 & 0.2129 & 0.2257 \\
\hline Hour & 13 & 14 & 15 & 16 & 17 & 18 & 19 & 20 & 21 & 22 & 23 & 24 \\
\hline kW-hr/hr & 0.2557 & 0.2929 & 0.3329 & 0.3800 & 0.4271 & 0.4571 & 0.4671 & 0.4271 & 0.3571 & 0.2871 & 0.2271 & 0.1600 \\
\hline
\end{tabular}

The RAC load shape based on the data shown in Table 3.12 is shown in Figure 3.3 below. 


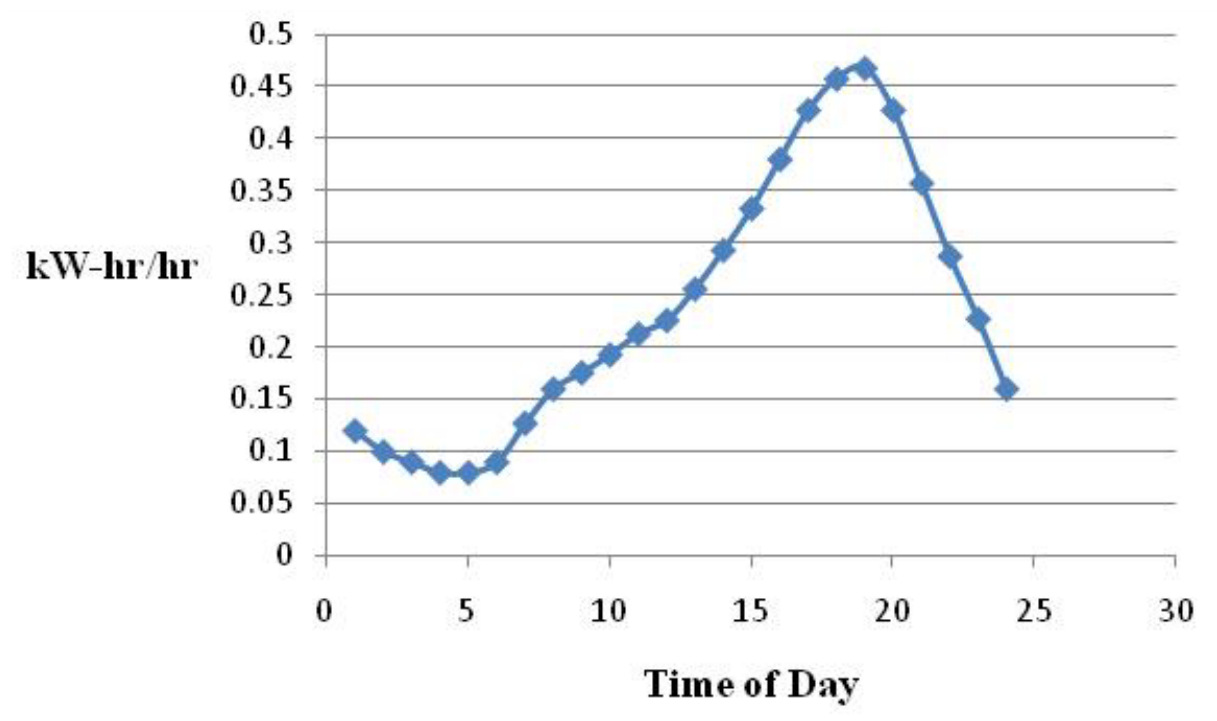

Figure 3.3. ELCAP RAC Load Shape for an Average Summer Day

\subsubsection{Freezer Load Shape}

The hourly electricity consumption by a freezer on an average annual day is shown below in Table 3.13 .

Table 3-13. ELCAP Freezer Hourly Consumption on an Average Annual Day

\begin{tabular}{|c|c|c|c|c|c|c|c|c|c|c|c|c|}
\hline Hour & 1 & 2 & 3 & 4 & 5 & 6 & 7 & 8 & 9 & 10 & 11 & 12 \\
\hline kW-hr/hr & 0.1733 & 0.1739 & 0.1716 & 0.1671 & 0.1674 & 0.1654 & 0.1610 & 0.1580 & 0.1597 & 0.1627 & 0.1656 & 0.1709 \\
\hline Hour & 13 & 14 & 15 & 16 & 17 & 18 & 19 & 20 & 21 & 22 & 23 & 24 \\
\hline kW-hr/hr & 0.1776 & 0.1811 & 0.1821 & 0.1831 & 0.1873 & 0.1917 & 0.1923 & 0.1900 & 0.1890 & 0.1860 & 0.1807 & 0.1750 \\
\hline
\end{tabular}

The freezer load shape based on the data shown in Table 3.13 is shown in Figure 3.4 below. 


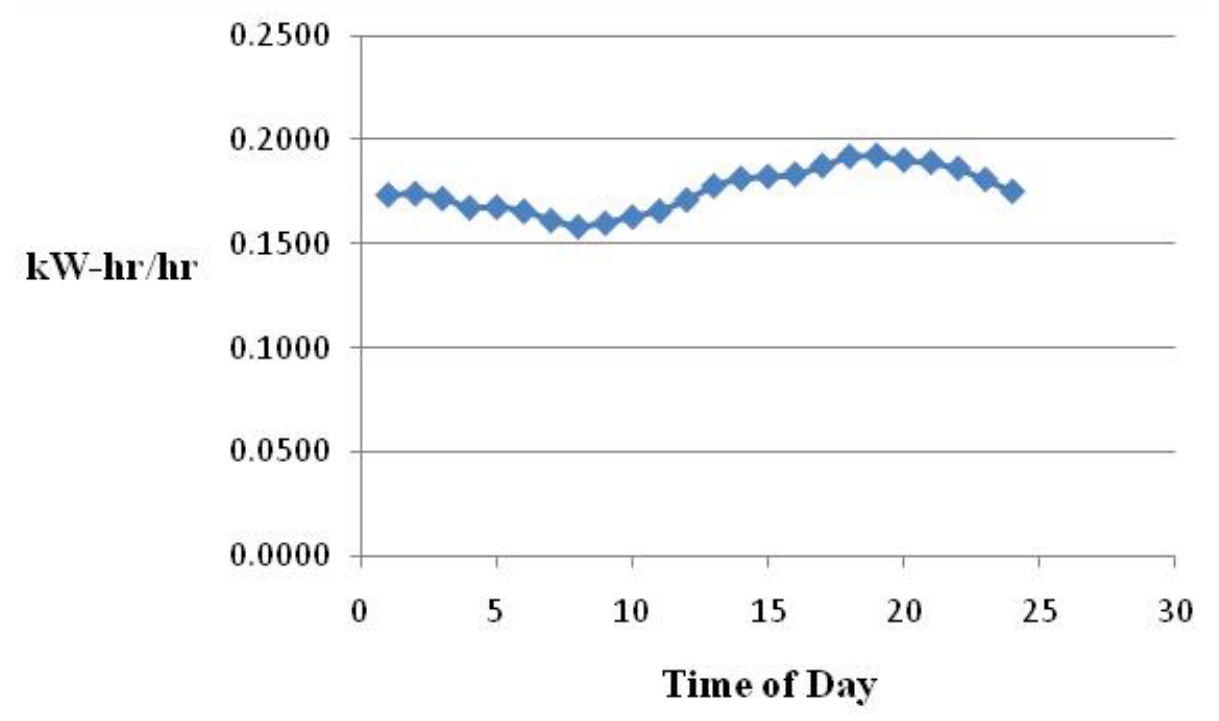

Figure 3.4. ELCAP Freezer Load Shape for an Average Annual Day

\subsubsection{Refrigerator Load Shape}

The hourly electricity consumption by a refrigerator on an average annual day is shown below in Table 3.14.

Table 3-14. ELCAP Refrigerator Hourly Consumption on an Average Annual Day

\begin{tabular}{|c|c|c|c|c|c|c|c|c|c|c|c|c|}
\hline Hour & 1 & 2 & 3 & 4 & 5 & 6 & 7 & 8 & 9 & 10 & 11 & 12 \\
\hline kW-hr/hr & 0.1636 & 0.1603 & 0.1553 & 0.1510 & 0.1483 & 0.1511 & 0.1581 & 0.1627 & 0.1644 & 0.1666 & 0.1656 & 0.1663 \\
\hline Hour & 13 & 14 & 15 & 16 & 17 & 18 & 19 & 20 & 21 & 22 & 23 & 24 \\
\hline kW-hr/hr & 0.1736 & 0.1741 & 0.1727 & 0.1751 & 0.1823 & 0.1949 & 0.2017 & 0.1963 & 0.1919 & 0.1883 & 0.1806 & 0.1703 \\
\hline
\end{tabular}

The refrigerator load shape based on the data shown in Table 3.14 is shown in Figure 3.5 below. 


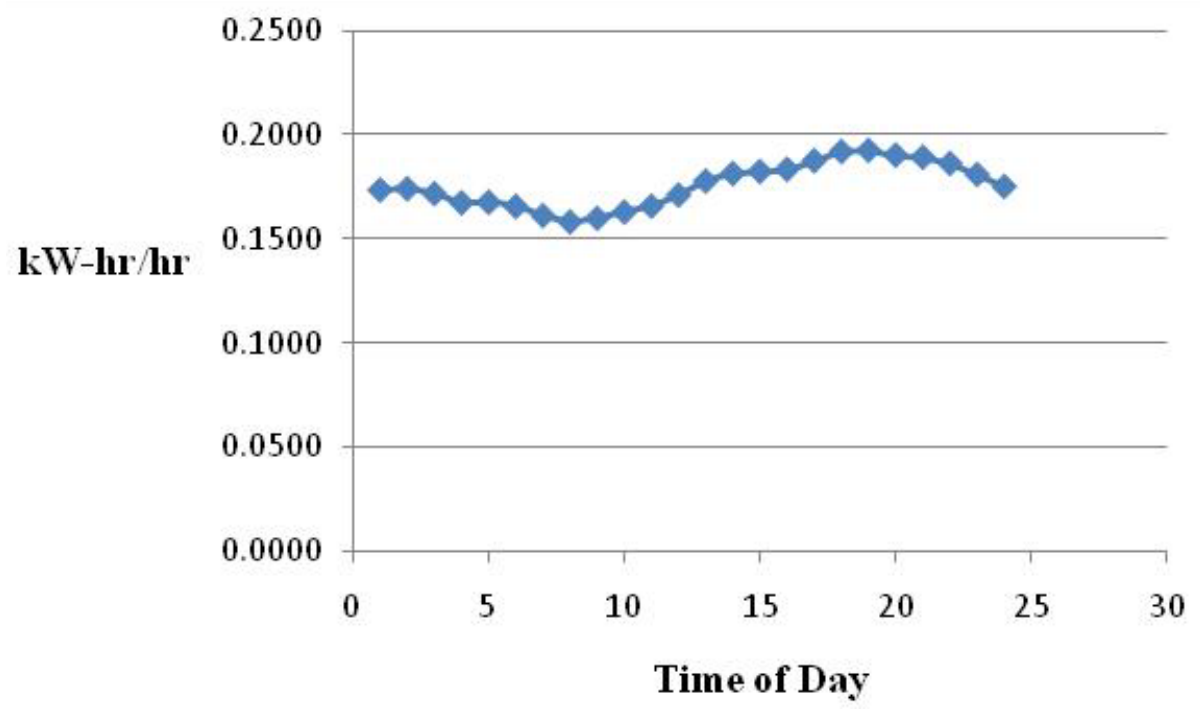

Figure 3.5. ELCAP Refrigerator Load Shape for an Average Annual Day

\subsubsection{Clothes Washer (CW) Load Shape}

The hourly electricity consumption by a $\mathrm{CW}$ on an average annual day is shown below in Table 3.15

Table 3-15. ELCAP CW Hourly Consumption on an Average Annual Day

\begin{tabular}{|c|c|c|c|c|c|c|c|c|c|c|c|c|}
\hline Hour & 1 & 2 & 3 & 4 & 5 & 6 & 7 & 8 & 9 & 10 & 11 & 12 \\
\hline kW-hr/hr & 0.0029 & 0.0019 & 0.0015 & 0.0014 & 0.0018 & 0.0030 & 0.0054 & 0.0112 & 0.0177 & 0.0223 & 0.0238 & 0.0226 \\
\hline Hour & 13 & 14 & 15 & 16 & 17 & 18 & 19 & 20 & 21 & 22 & 23 & 24 \\
\hline kW-hr/hr & 0.0203 & 0.0180 & 0.0156 & 0.0145 & 0.0151 & 0.0156 & 0.0157 & 0.0155 & 0.0154 & 0.0144 & 0.0103 & 0.0059 \\
\hline
\end{tabular}

The CW load shape based on the data shown in Table 3.14 is shown in Figure 3.6 below. 


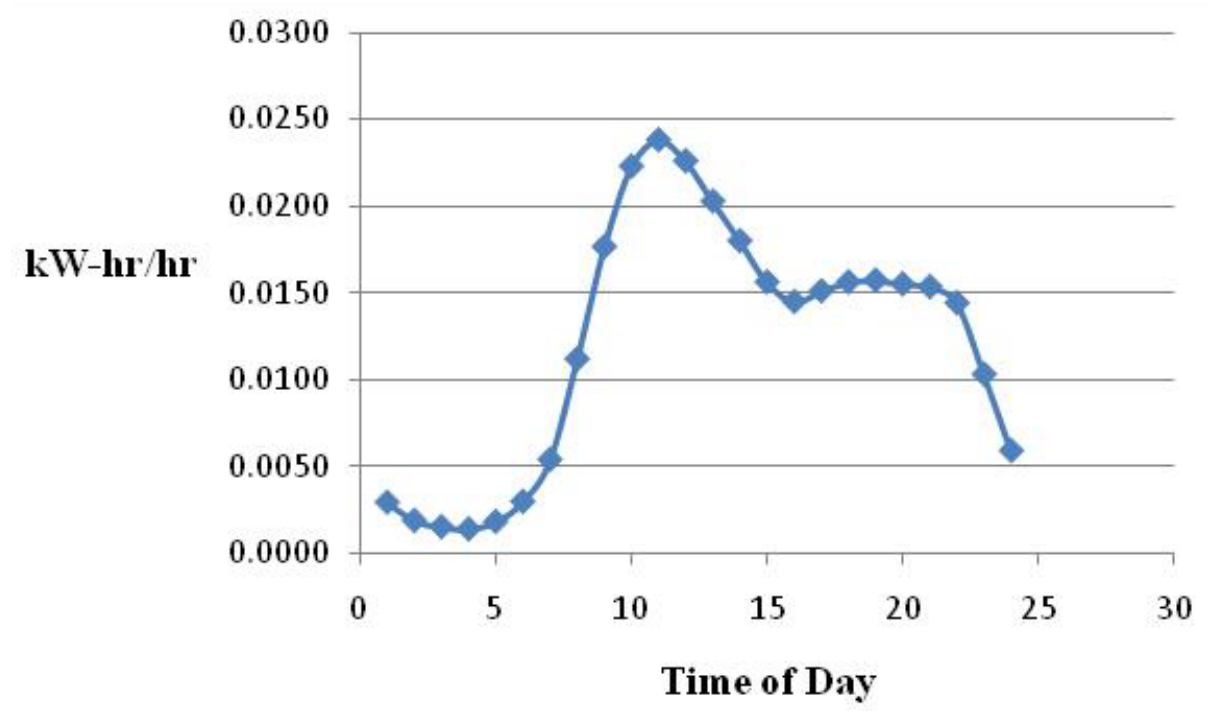

Figure 3.6. ELCAP CW Load Shape for an Average Annual Day

\subsection{Smart Appliance Benefits Based on Wholesale Power Production Costs}

In this section, we present the analytical model used to estimate the benefits of the smart appliances we consider in this report. The benefits are estimated in terms of the savings in wholesale power production costs.

First, we define below various quantities needed in our calculations.

\subsubsection{Notation}

Let $f p$ denote the ratio of total annual electricity consumption during on-peak hours to total annual electricity consumption over all hours for each appliance (estimated from definitions of on-peak and offpeak hours listed in 3.1.1, and ELCAP load shapes presented in 3.3).

This ratio depends on the definition of on-peak hours and the number of days in a year those on-peak hours are in effect (say $N_{p}$ ) and is given by

$$
f_{p}=\left(l_{p} * N_{p}\right) /(365 * l)
$$

where $l_{p}=$ daily on-peak consumption (load), and $l=$ daily total consumption as given by the ELCAP load shape. For example, in the case of a dryer, we have $l_{p}=1.06 \mathrm{kWh} /$ day, $l=2.89 \mathrm{~kW} /$ day, and $N_{p}=$ 365 , giving us $f_{p}=0.37$.

\section{Let}




$$
L^{7}=\text { Total annual electricity consumption for each appliance (see Section 3.1.2) }
$$

Then

Total annual on-peak hours of electricity consumption for each $\quad=f_{p} * L$ appliance

and

Total annual off-peak hours electricity consumption for each $\quad=\left(1-f_{p}\right) * L$

appliance

In Section 3.2, we presented hourly average wholesale market-clearing prices, both LMP and spinning reserves. In order to express costs and benefits in terms of those prices, let

- $C_{e p}=$ Hourly average energy cost for on-peak hours (LMP)

- $C_{\text {eop }}=$ Hourly average energy cost for off-peak hours (LMP)

- $C_{\text {est }}=$ Hourly average energy cost for "shift-to" hours (LMP)

- $C_{\text {srp }}=$ Hourly average cost of spinning reserves for on-peak hours

- $C_{\text {srop }}=$ Hourly average cost of spinning reserves for off-peak hours

- $C_{\text {srst }}=$ Hourly average cost of spinning reserves for "shift-to" hours

Note that if, as assumed in Section 3.1.1, the "shift-to" hours are the same as the off-peak hours, then

$$
C_{\text {eop }}=C_{\text {est }} \text {, and } C_{\text {srop }}=C_{\text {srst }}
$$

Finally, let $p \%$ denote the "Net Fraction of On-Peak Load Available to Shift peak load-shift" fraction discussed in Section 3.1.3.

With all of the above definitions, we now evaluate the benefits (power production cost savings) of smart appliances to peak load shifting and spinning reserves. We first consider peak load shifting.

\subsubsection{Smart Appliance Benefits: Peak Load Shifting}

The operation of any appliance would incur a certain annual wholesale market cost. However, a smart appliance, by virtue of its ability to shift its operation from peak hours to off-peak or "shift-to" hours, will result in savings in wholesale market costs. This is due to the fact that off-peak wholesale prices are typically lower than on-peak wholesale prices. We express these savings in terms of the various quantities we defined above.

The annual energy cost $C_{A}$ for running an appliance in normal mode is the sum of the cost of on-peak consumption and the cost of off-peak consumption. Using the expressions for on-peak consumption

\footnotetext{
${ }^{7}$ In the case of CWs and DWs, L must account for the fact that CWs and DWs utilize resident hot water heaters for their hot water supply, and not all hot water heaters are electricity based. Some are gas fired. See the CW and DW results in Sections 4.6 and 4.7 where we take this into account.
} 
(Equation 1) and off-peak consumption (Equation 2), we get

$$
C_{A}=C e p * f p * L+C e o p *(1-f p) * L
$$

Annual energy cost $C_{\text {AST }}$ for running an appliance with peak load shifted to "shift-to" hours (peak load will be valued at annual hourly average energy cost for "shift-to" hours) will be:

$$
C_{A S T}=C_{e s t} * f p * L+C e o p *(1-f p) * L
$$

Maximum annual savings ( $S_{P L S}$ ) in energy cost resulting from $100 \%$ appliance peak load shifted to "shift to" hours: Equation 3 - Equation 4.

$$
S_{P L S}=f_{p} * L^{*}(C e p-C e s t)
$$

Annual savings ( $S_{P L S}$ ) in energy cost resulting from $p \%$ of appliance peak load shifted to "shift to" hours is then given by

$$
S_{P L S}=f p * L^{*}(C e p-C e s t)
$$

\subsubsection{Smart Appliance Benefits: Spinning Reserves}

In Section 2.2, we motivated the use of smart appliances to provide spinning reserves. To reiterate very briefly, spinning reserves are typically provided by generators that are already synchronized to the grid, by releasing capacity set aside in response to a contingency signal from an ISO/RTO. We recap below the characteristic features of spinning reserves

Spinning reserves are in general a part of contingency reserves (which include non-spinning reserves) that are set aside as unused capacity to be invoked in the event of a contingency such as loss of a generator or a transmission line. Spinning reserves need to be maintained ALL THE TIME, i.e., every hour, every day, throughout the year.

1. Spinning reserves are typically provided by generators that are already synchronized to the grid, by operating them below their rated capacity, and releasing this unused capacity in response to a contingency signal from an ISO/RTO. NERC requires that spinning reserves be released within 10 minutes of receiving a contingency signal.

2. While there is no fixed requirement on how long spinning reserves must be deployed once called upon, historically, it has been observed in various ISO/RTO markets that , that if called upon, generators must provide this installed capacity for about 10 minutes, by which time other reserves are deployed. Furthermore, the required spinning reserve capacity is on the order of 5 percent of demand or so). Thus, instead of generators, this same function can be provided by a smart appliance that is ready and willing to reduce load temporarily in response to a signal to do so.

3. Note: The premise in this report is that instead of generators supplying spinning reserves, smart appliances curtail their operation for 10 minutes in response to a contingency signal. Thus, the ELCAP appliance load shapes presented in 3.3 serve as the available "capacity" in the sense that at 
any time an appliance is operating, it is available for curtailment, and in this sense it is installed capacity for spinning reserves.

4. Spinning reserves are basically an opportunity cost to power producers; they bid spinning reserve capacity in the open wholesale market. Power producers are compensated for spinning reserves based on the capacity they have set aside each hour for spinning reserves, and the market clearing price for that hour (units: $\$ / M W-h r$ ). Note that this is slightly different from $\$ / M W H$ (which is cost for energy delivered).

A more formal description of how spinning reserves are valued is as follows. Let $c_{i}$ denote the capacities set aside for spinning reserves for each hour $i(i=1,2, \ldots)$. Let $p_{i}$ denote the wholesale marketclearing price for spinning reserves for the hour $i$. Then the value $V_{S R}$ of spinning reserves at which power producers are compensated is given by

$$
V_{S R}=\sum_{i} c_{i}^{*} p_{i}
$$

As an example, assume an average cost of spinning reserves of $\$ 10 / \mathrm{MW}-\mathrm{hr}$ (it varies by market and from hour to hour). Then if the average all-hours installed spinning reserve capacity is, say, $10 \mathrm{MW}$ $\mathrm{hr} / \mathrm{hr}$, then the annual cost of spinning reserves is

$$
8760 \text { (hours/year) * } 10 \mathrm{MW}-\mathrm{hr} / \mathrm{hr} * \$ 10 / \mathrm{MW}-\mathrm{hr}=\$ 876,000 / \text { year }
$$

For our purpose, we rearrange Equation 7 as follows:

$$
V_{S R}=V_{S R P}+V_{S R O P}
$$

where $V_{S R P}$ and $V_{S R O P}$ are spinning-reserve values during on-peak and off-peak hours, respectively, and are given by

$$
\begin{aligned}
& V_{S R P}=\sum_{i \in\{\text { on-peak hours }\}} c_{i} * p_{i} \\
& V_{S R P}=\sum_{i \in\{\text { on-peak hours }\}} c_{i}^{*} p_{i}
\end{aligned}
$$

If we replace hourly on-peak and off-peak wholesale spinning-reserve market-clearing prices with their average values $C_{\text {srp }}$ and $C_{\text {srop }}$, respectively, it follows that Equation 9 and Equation 10 can be rewritten as

$$
\begin{aligned}
& V_{S R P}=C_{\text {srp }} * \sum_{i \in\{\text { on }- \text { peak hours }\}} c_{i} \\
& V_{\text {SROP }}=C_{\text {srop }} * \sum_{i \in\{\text { off }- \text { peak hours }\}} c_{i}
\end{aligned}
$$


Now, let us consider smart appliances in place of generators as sources for spinning reserves. Then, from Equations 1 and 2, which were derived based on ELCAP load shapes and annual appliance consumption $L$, we have

$$
\sum_{i \in\{\text { peakhours }\}} c_{i}=f_{p} * L
$$

and

$$
\sum_{i \in\{\text { off }- \text { peak hours }\}} c_{i}=\left(1-f_{p}\right)^{*} L
$$

It then follows from Equations 11 and 12 that,

$$
V_{S R P}=C_{s r p} * f_{p} * L
$$

and

$$
V_{S R O P}=C_{\text {srop }} *\left(1-f_{p}\right) * L
$$

Now if $p \%$ of appliance peak load were shifted to "shift-to" hours, then it follows that appliance load available during on-peak hours is reduced by a factor of (1-p), and the remaining peak load is available as additional spinning reserves during off-peak hours but valued at $C_{\text {srst. }}$ Thus,

$$
V_{S R P}=(1-p) * f p * L * C s r p
$$

and

$$
V_{\text {SROP }}=p * f_{p} * L * C_{\text {srst }}+\left(1-f_{p}\right) * L^{*} C_{\text {srop }}
$$

Thus, the total spinning reserve value $V_{S R}$ from each smart appliance is Equation 17 + Equation 18, and after some re-arranging of terms is given by

$$
V_{S R}=f_{p} * L *\left(C_{s p p}-C_{\text {srop }}\right)+L * C_{\text {srop }}-p^{*} f_{p} * L^{*}\left(C_{\text {srp }}-C_{\text {srst }}\right)
$$

Note that in deriving Equation (19), we have assumed that all of an appliance annual electricity consumption $L$ is available for spinning reserves. In general, VSR must be discounted by the factor "Net Fraction of Load Available for Spinning Reserves" which was described in Section 3.1.4. 


\subsection{Smart Appliance Benefit-to-Cost Ratios}

In this section we first examine smart appliance benefit-to-cost ratio in general. Then, we present the benefit-to-cost ratios of each smart appliance.

\subsection{Benefits-to-Cost Ratio: General}

Recall that in this report, by "benefits" we mean savings in wholesale power-production costs. In Section 3.4.2, we evaluated the benefits $S_{P L S}$ of smart appliances resulting from peak-load shifting (Equation 6). In Section 3.4.3, we evaluated the benefits $V_{S R}$ resulting from smart appliances serving as sources of spinning reserves (Equation 19). The net smart-appliance benefits, B, are found by adding Equation 6 and Equation 19, and rearranging terms as follows:

$$
B=f_{p} * L^{*}\left(C_{s r p}-C_{s r o p}\right)+L^{*} C_{s r o p}+p^{*} f_{p} * L^{*}\left(C_{e p}-C_{e s t}-C_{s r p}+C_{s r s t}\right)
$$

For the purpose of this report, the "cost" of a smart appliance is defined as follows. Recall, AHAM and other stakeholders are petitioning the EPA for a "credit" on current appliance standards, so that appliance manufactures can use that credit to invest in smart appliances and spur the market for smart appliances. Let this credit be denoted by $C R$. (The current value of $C R$ as per the petition is 5\%). Now, based on current appliance standards, the annual operating cost $C_{A}$ for each appliance is given by Equation 3, which we reproduce here for convenience:

$$
C_{A}=C_{e p} * f_{p} * L+C_{e o p} *\left(1-f_{p}\right) * L
$$

The credit $C R$ is applied against $C_{A}$, which is interpreted as the "cost" $C$, and is given by

$$
C=C_{A} *\left[C_{e p} * f_{p} * L+C_{e o p} *\left(1-f_{p}\right) * L\right]
$$

The benefit-to-cost ratio is thus given by

$$
B / C=[f p *(C s r p-C s r o p)+C s r o p+p * f p *(C e p-C e s t-C s r p+C s r s t)] / C R *[C e p * f p+C e o p *(1-f p)]
$$

We make three important observations from Equations 20, 22, and 23:

1. The absolute values of both benefits and costs depend on all the quantities we have in our assumptions as described in Section 3.1.

2. However, the benefit-to-cost ratio given by Equation 23 is independent of each smart appliance's annual electricity consumption. It of course depends on the load shape (the parameter $f_{p}$ ), load shift fraction $p$, smart-appliance credit $\mathrm{CR}$, and wholesale market-clearing prices.

3. The benefit-to-cost ratio gives an indication of how valuable the smart appliance benefits are with respect to cost. We expect the ratio to be greater than or equal to 1 in order for the credit to be costeffective. 
We now present the benefit-to-cost ratios of each appliance. All the tables that will be presented henceforth are taken from the smart-appliance cost/benefit analysis spreadsheet that was developed as part of this project.

\subsection{Benefit-to-Cost Ratios: Smart Clothes Dryers (CD)}

In this section, we estimate the benefit-to-cost ratio of smart CDs in various markets based on both optimistic and pessimistic sets of assumptions.

\subsubsection{High-End Optimistic Results}

We first present below in Table 4.1 the annual on-peak and off-peak electricity consumption based on the optimistic assumptions presented in Section 3.1.

Table 4-1. CD On-Peak and Off-Peak Consumption Based on ELCAP Average Annual Day Load Shape and Optimistic Assumptions

\begin{tabular}{|r|c|c|c|c|c|c|c|}
\hline \multicolumn{4}{|c|}{ ELCAP (1990) Dryer Load Shape } & \multicolumn{3}{c|}{2010 Annual Dryer On-Peak and Off-Peak } \\
Consumption
\end{tabular}

Based on the data shown in Table 4.1, high-end wholesale power production cost savings using smart CDs for peak load shifting are shown in Table 4.2 below.

Table 4-2. Wholesale Cost Savings from Using Smart CDs for Peak Load Shifting - Optimistic View

\begin{tabular}{|c|c|c|c|c|c|c|c|}
\hline \multirow[b]{3}{*}{ Market and Year } & \multicolumn{3}{|c|}{ Annual Hourly Energy Market Clearing Prices } & \multicolumn{2}{|c|}{$\begin{array}{l}\text { Annual Energy Cost } \\
\text { (No Load Shift) }\end{array}$} & \multicolumn{2}{|c|}{$\begin{array}{c}\text { Annual Energy Cost Savings from } \\
100 \% \text { Peak Load Shift }\end{array}$} \\
\hline & Avg. On-Peak & Avg. Off-Peak & $\begin{array}{l}\text { Avg. Shift- } \\
\text { To Hours }\end{array}$ & On-Peak & Off-Peak & $\begin{array}{c}\text { On-Peak } \\
\text { Energy Moved } \\
\text { to "Shift To" } \\
\text { Hours }\end{array}$ & Savings \\
\hline & (\$/MWh) & (\$/MWh) & (\$/MWh) & (\$/yr) & (\$/yr) & (kWh/yr) & (\$/yr) \\
\hline PJM 2006 & $\$ 50.64$ & $\$ 39.44$ & $\$ 39.44$ & $\$ 12.23$ & $\$ 16.43$ & 241.54 & $\$ 2.70$ \\
\hline ERCOT 2008 & $\$ 105.56$ & $\$ 67.09$ & $\$ 67.09$ & $\$ 25.50$ & $\$ 27.94$ & 241.54 & $\$ 9.29$ \\
\hline NYISO 2008 & $\$ 115.97$ & $\$ 92.25$ & $\$ 92.27$ & $\$ 28.01$ & $\$ 38.42$ & 241.54 & $\$ 5.73$ \\
\hline NYISO 2006 & $\$ 85.05$ & $\$ 67.44$ & $\$ 67.41$ & $\$ 20.54$ & $\$ 28.09$ & 241.54 & $\$ 4.26$ \\
\hline CAISO 2008 & $\$ 82.11$ & $\$ 65.01$ & $\$ 65.02$ & $\$ 19.83$ & $\$ 27.07$ & 241.54 & $\$ 4.13$ \\
\hline
\end{tabular}


The high-end wholesale cost savings from using smart CDs for providing spinning reserves is shown in Table 4.3 below

Table 4-3. Wholesale Cost Savings from Using Smart CDs for Spinning Reserves - Optimistic View

\begin{tabular}{|c|c|c|c|c|c|c|}
\hline \multirow[b]{3}{*}{ Market and Year } & \multicolumn{3}{|c|}{ Annual Hourly SR Market Clearing Prices } & \multicolumn{3}{|c|}{ Annual Dryer SR Market Value } \\
\hline & Avg. On-Peak & Avg. Off-Peak & $\begin{array}{c}\text { Avg. Shift- } \\
\text { To Hours }\end{array}$ & $\begin{array}{l}\text { On Peak: From Dryer Load } \\
\text { After } 100 \% \text { Shifted }\end{array}$ & $\begin{array}{l}\text { Off-Peak: From Dryer Off- } \\
\text { Peak Load + } 100 \% \text { Load shifted } \\
\text { from Peak to 'Shift To' Hours }\end{array}$ & \begin{tabular}{|c} 
Total Spinning \\
Reserve Cost \\
Savings
\end{tabular} \\
\hline & (\$/MWh) & (\$/MWh) & (\$/MWh) & (\$/yr) & $(\$ / y r)$ & $(\$ / y r)$ \\
\hline PJM 2006 & $\$ 7.29$ & $\$ 8.08$ & $\$ 8.08$ & $\$ 0.00$ & $\$ 5.32$ & $\$ 5.32$ \\
\hline ERCOT 2008 & $\$ 36.85$ & $\$ 23.76$ & $\$ 23.76$ & $\$ 0.00$ & $\$ 15.63$ & $\$ 15.63$ \\
\hline NYISO 2008 & $\$ 14.84$ & $\$ 8.56$ & $\$ 8.56$ & $\$ 0.00$ & $\$ 5.63$ & $\$ 5.63$ \\
\hline NYISO 2006 & $\$ 12.40$ & $\$ 5.42$ & $\$ 5.42$ & $\$ 0.00$ & $\$ 3.57$ & $\$ 3.57$ \\
\hline CAISO 2008 & $\$ 13.26$ & $\$ 3.56$ & $\$ 3.57$ & $\$ 0.00$ & $\$ 2.35$ & $\$ 2.35$ \\
\hline
\end{tabular}

The additional $6 \%$ optimistic electricity consumption and cost savings resulting from providing energy-use feedback to customers is shown below in Table 4.4.

Table 4-4. Additional 6\% Savings Resulting from CD Consumption Feedback to Customers

\begin{tabular}{|r|c|c|}
\hline Market and Year & $\mathbf{( k W h / y r )}$ & $\mathbf{( \$ / y r )}$ \\
\hline PJM 2006 & 39 & $\$ 1.72$ \\
\hline ERCOT 2008 & 39 & $\$ 3.21$ \\
\hline NYISO 2008 & 39 & $\$ 3.99$ \\
\hline NYISO 2006 & 39 & $\$ 2.92$ \\
\hline CAISO 2008 & 39 & $\$ 2.81$ \\
\hline
\end{tabular}

Finally, the overall high-end benefits (wholesale cost saving resulting from peak-load shifting, spinning reserves, and consumer feedback combined) are shown in Table 4.5 below. 
Table 4-5. Smart CD Benefits (Peak Load Shift + Spinning Reserves + Feedback Effect)-to-Cost Ratio Optimistic View

\begin{tabular}{|r|c|c|c|}
\hline & $\begin{array}{c}\text { Grid } \\
\text { Operational } \\
\text { Cost Savings } \\
\text { (Benefits) }\end{array}$ & $\begin{array}{c}\text { Cost of } \\
\text { Additional } \\
\text { Energy } \\
\text { Consumption } \\
\text { at 5\% Credit }\end{array}$ & $\begin{array}{c}\text { Benefits to } \\
\text { Cost Ratio }\end{array}$ \\
\cline { 2 - 4 } Market and Year & $\mathbf{( \$ / y r )}$ & $\mathbf{( \$ / y r )}$ & $(-)$ \\
\hline PJM 2006 & $\$ 9.74$ & $\$ 1.43$ & $\mathbf{6 8 0 \%}$ \\
\hline ERCOT 2008 & $\$ 28.13$ & $\$ 2.67$ & $\mathbf{1 0 5 3 \%}$ \\
\hline NYISO 2008 & $\$ 15.35$ & $\$ 3.32$ & $\mathbf{4 6 2 \%}$ \\
\hline NYISO 2006 & $\$ 10.74$ & $\$ 2.43$ & $\mathbf{4 4 2 \%}$ \\
\hline CAISO 2008 & $\$ 9.29$ & $\$ 2.35$ & $\mathbf{3 9 6 \%}$ \\
\hline & & & \\
\hline
\end{tabular}

Thus, as can be observed from Table 4.5 , the benefit-to-cost ratios overwhelmingly exceed $100 \%$ in all markets.

\subsubsection{Low-End Pessimistic Results}

We first present below in Table 4.6 the annual on-peak and off-peak electricity consumption based on the optimistic assumptions presented in Section 3.1.

Table 4-6. CD On-Peak and Off-Peak Consumption Based on ELCAP Average Annual Day Load Shape and Pessimistic Assumptions

\begin{tabular}{|r|c|c|c|c|c|c|c|}
\hline \multicolumn{4}{|c|}{ ELCAP (1990) Dryer Load Shape } & \multicolumn{3}{c|}{2010 Annual Dryer On-Peak and Off-Peak } \\
Consumption
\end{tabular}

Based on the data shown in Table 4.6, high-end wholesale power production cost savings using smart CDs for peak load shifting are shown below in Table 4.7. 
Table 4-7. Wholesale Cost Savings from Using Smart CDs for Peak-Load Shifting - Pessimistic View

\begin{tabular}{|c|c|c|c|c|c|c|c|}
\hline \multirow[b]{3}{*}{ Market and Year } & \multicolumn{3}{|c|}{ Annual Hourly Energy Market Clearing Prices } & \multicolumn{2}{|c|}{$\begin{array}{l}\text { Annual Energy Cost } \\
\text { (No Load Shift) }\end{array}$} & \multicolumn{2}{|c|}{$\begin{array}{c}\text { Annual Energy Cost Savings from } \\
18 \% \text { Peak Load Shift }\end{array}$} \\
\hline & Avg. On-Peak & Avg. Off-Peak & $\begin{array}{l}\text { Avg. Shift- } \\
\text { To Hours }\end{array}$ & On-Peak & Off-Peak & $\begin{array}{c}\text { On-Peak } \\
\text { Energy Moved } \\
\text { to "Shift To" } \\
\text { Hours }\end{array}$ & Savings \\
\hline & (\$/MWh) & (\$/MWh) & (\$/MWh) & $(\$ / y r)$ & $(\$ / y r)$ & (kWh/yr) & (\$/yr) \\
\hline PJM 2006 & $\$ 55.55$ & $\$ 40.45$ & $\$ 42.90$ & $\$ 6.25$ & $\$ 22.06$ & 19.70 & $\$ 0.25$ \\
\hline ERCOT 2008 & $\$ 119.27$ & $\$ 70.95$ & $\$ 73.03$ & $\$ 13.43$ & $\$ 38.70$ & 19.70 & $\$ 0.91$ \\
\hline NYISO 2008 & $\$ 120.56$ & $\$ 95.16$ & $\$ 94.83$ & $\$ 13.57$ & $\$ 51.90$ & 19.70 & $\$ 0.51$ \\
\hline NYISO 2006 & $\$ 93.91$ & $\$ 68.87$ & $\$ 72.50$ & $\$ 10.57$ & $\$ 37.57$ & 19.70 & $\$ 0.42$ \\
\hline CAISO 2008 & $\$ 88.25$ & $\$ 66.72$ & $\$ 68.67$ & $\$ 9.93$ & $\$ 36.39$ & 19.70 & $\$ 0.39$ \\
\hline
\end{tabular}

The low-end wholesale cost savings from using smart CDs for providing spinning reserves is shown in Table 4.8 below.

Table 4-8. Wholesale Cost Savings from Using Smart CDs for Spinning Reserves - Pessimistic View

\begin{tabular}{|r|c|c|c|c|c|c|}
\hline & \multicolumn{2}{|c|}{ Annual Hourly SR Market Clearing Prices } & \multicolumn{3}{c|}{ Annual Dryer SR Market Value } \\
\cline { 2 - 8 } & Avg. On-Peak & Avg. Off-Peak & $\begin{array}{c}\text { Avg. Shift- } \\
\text { To Hours }\end{array}$ & $\begin{array}{c}\text { On Peak: From Dryer Load } \\
\text { After 18\% Shifted }\end{array}$ & $\begin{array}{c}\text { Off-Peak: From Dryer Off- } \\
\text { Peak Load + 18\% Load shifted } \\
\text { from Peak to 'Shift To' Hours }\end{array}$ & $\begin{array}{c}\text { Total Spinning } \\
\text { Reserve Cost } \\
\text { Savings }\end{array}$ \\
Market and Year & $(\$ / M W h)$ & $(\$ / M W h)$ & $(\$ / M W h)$ & $(\$ / y r)$ & $\$ 1 / y r)$ \\
\hline PJM 2006 & $\$ 7.30$ & $\$ 7.96$ & $\$ 8.29$ & $\$ 0.24$ & $\$ 1.62$ & $\$ 1.87$ \\
\hline ERCOT 2008 & $\$ 37.51$ & $\$ 25.61$ & $\$ 25.54$ & $\$ 1.25$ & $\$ 5.21$ & $\$ 6.46$ \\
\hline NYISO 2008 & $\$ 14.38$ & $\$ 9.56$ & $\$ 9.16$ & $\$ 0.48$ & $\$ 1.94$ & $\$ 2.42$ \\
\hline NYISO 2006 & $\$ 16.02$ & $\$ 5.97$ & $\$ 7.62$ & $\$ 0.54$ & $\$ 1.23$ & $\$ 1.76$ \\
\hline CAISO 2008 & $\$ 14.95$ & $\$ 4.78$ & $\$ 4.30$ & $\$ 0.50$ & $\$ 0.97$ & $\$ 1.47$ \\
\hline
\end{tabular}

The additional 3\% pessimistic electricity consumption and cost savings resulting from providing energy-use feedback to customers is shown below in Table 4.9

Table 4-9. Additional 3\% Savings Resulting from CD Consumption Feedback to Customers

\begin{tabular}{|r|c|c|}
\hline Market and Year & $\mathbf{( k W h / y r )}$ & $\mathbf{( \$ / y r )}$ \\
\hline PJM 2006 & 20 & $\$ 0.85$ \\
\hline ERCOT 2008 & 20 & $\$ 1.56$ \\
\hline NYISO 2008 & 20 & $\$ 1.96$ \\
\hline NYISO 2006 & 20 & $\$ 1.44$ \\
\hline CAISO 2008 & 20 & $\$ 1.39$ \\
\hline
\end{tabular}


Finally, the overall low-end benefits (wholesale cost saving resulting from peak-load shifting, spinning reserves, and consumer feedback combined) are shown in Table 4.10 below.

Table 4-10. Smart CD Benefit (Peak Load Shift + Spinning Reserves + Feedback Effect)-to-Cost Ratio Pessimistic View

\begin{tabular}{|r|c|c|c|}
\hline & $\begin{array}{c}\text { Grid } \\
\text { Operational } \\
\text { Cost Savings } \\
\text { (Benefits) }\end{array}$ & $\begin{array}{c}\text { Cost of } \\
\text { Additional } \\
\text { Energy } \\
\text { Consumption } \\
\text { at 5\% Credit }\end{array}$ & Benefits to \\
Cost Ratio & \\
\cline { 2 - 4 } Market and Year & $\mathbf{( \$ / y r )}$ & $\mathbf{\$} / \mathbf{y r})$ & $(-)$ \\
\hline PJM 2006 & $\$ 2.96$ & $\$ 1.42$ & $\mathbf{2 0 9 \%}$ \\
\hline ERCOT 2008 & $\$ 8.94$ & $\$ 2.61$ & $343 \%$ \\
\hline NYISO 2008 & $\$ 4.89$ & $\$ 3.27$ & $149 \%$ \\
\hline NYISO 2006 & $\$ 3.63$ & $\$ 2.41$ & $151 \%$ \\
\hline CAISO 2008 & $\$ 3.24$ & $\$ 2.32$ & $140 \%$ \\
\hline & & & \\
\hline
\end{tabular}

Thus, as can be observed from Table 4.10, the benefit-to-cost ratios exceed $100 \%$ even for the pessimistic set of assumptions in all markets.

\subsection{Benefit-to-Cost Ratios: Room Air Conditioners (RACs)}

In this section, we estimate the benefit-to-cost ratio of smart RACs in various markets based on both optimistic and pessimistic sets of assumptions. Note that, unlike other appliances, for RACs we utilize the ELCAP summer load shape to estimate on-peak and off-peak consumption. We assume no RAC consumption during the non-summer months.

\subsubsection{High-End Optimistic Results}

We first present below in Table 4.11 the annual on-peak and off-peak electricity consumption of RACs based on the optimistic assumptions presented in Section 3.1. 
Table 4-11. RAC On-Peak and Off-Peak Consumption Based on ELCAP Average Summer Day Load Shape and Optimistic Assumptions

\begin{tabular}{|c|c|c|c|c|c|c|}
\hline \multicolumn{4}{|c|}{ ELCAP (1990) Room Air Conditioner Load Shape } & \multicolumn{3}{|c|}{$\begin{array}{l}2010 \text { Annual Room Air Conditioner On- } \\
\text { Peak and Off-Peak Consumption }\end{array}$} \\
\hline Load Shape: & Average Day & Summer & & Total & Annual On- & Annual Off- \\
\hline & Daily Total & On-Peak & \multirow{4}{*}{$\begin{array}{c}\text { Annual On- } \\
\text { Peak To } \\
\text { Total Ratio }\end{array}$} & Annual & Peak & Peak \\
\hline Start, Hour Ending: & 1 & 13 & & Consumptio & Consumption & Consumption \\
\hline \multirow[t]{3}{*}{ Through Hour Ending: } & 24 & 18 & & $\mathrm{n}(2010)$ & (2010) & (2010) \\
\hline & (kWh/day) & (kWh/day) & & (kWh/yr) & (kWh/yr) & (kWh/yr) \\
\hline & 5.73 & 2.15 & 0.37 & 693 & 260 & 433 \\
\hline
\end{tabular}

Based on the data shown in Table 4.11, high-end wholesale power production cost savings using smart RACs for peak load shifting are shown in Table 4.12 below.

Table 4-12. Wholesale Cost Savings from Using Smart RACs for Peak Load Shifting - Optimistic View

\begin{tabular}{|c|c|c|c|c|c|c|c|}
\hline \multirow[b]{3}{*}{ Market and Year } & \multicolumn{3}{|c|}{ Annual Hourly Energy Market Clearing Prices } & \multicolumn{2}{|c|}{$\begin{array}{l}\text { Annual Energy Cost } \\
\text { (No Load Shift) }\end{array}$} & \multicolumn{2}{|c|}{$\begin{array}{c}\text { Annual Energy Cost Savings from } \\
100 \% \text { Peak Load Shift }\end{array}$} \\
\hline & Avg. On-Peak & Avg. Off-Peak & $\begin{array}{l}\text { Avg. Shift- } \\
\text { To Hours }\end{array}$ & On-Peak & Off-Peak & $\begin{array}{c}\text { On-Peak } \\
\text { Energy Moved } \\
\text { to "Shift To" } \\
\text { Hours }\end{array}$ & Savings \\
\hline & (\$/MWh) & (\$/MWh) & (\$/MWh) & $(\$ / y r)$ & $(\$ / y r)$ & (kWh/yr) & $(\$ / y r)$ \\
\hline PJM 2006 & $\$ 66.12$ & $\$ 36.59$ & $\$ 36.59$ & $\$ 17.17$ & $\$ 15.85$ & 259.70 & $\$ 7.67$ \\
\hline ERCOT 2008 & $\$ 126.97$ & $\$ 73.33$ & $\$ 73.33$ & $\$ 32.97$ & $\$ 31.77$ & 259.70 & $\$ 13.93$ \\
\hline NYISO 2008 & $\$ 151.26$ & $\$ 93.35$ & $\$ 100.09$ & $\$ 39.28$ & $\$ 40.45$ & 259.70 & $\$ 13.29$ \\
\hline NYISO 2006 & $\$ 115.97$ & $\$ 64.36$ & $\$ 64.36$ & $\$ 30.12$ & $\$ 27.89$ & 259.70 & $\$ 13.40$ \\
\hline CAISO 2008 & $\$ 109.26$ & $\$ 69.76$ & $\$ 69.76$ & $\$ 28.38$ & $\$ 30.23$ & 259.70 & $\$ 10.26$ \\
\hline
\end{tabular}

The high-end wholesale cost savings from using smart RACs for providing spinning reserves is shown in Table 4.13 below.

Table 4-13. Wholesale Cost Savings from Using Smart RACs for Spinning Reserves - Optimistic View

\begin{tabular}{|c|c|c|c|c|c|c|}
\hline \multirow[b]{3}{*}{ Market and Year } & \multicolumn{3}{|c|}{ Annual Hourly SR Market Clearing Prices } & \multicolumn{3}{|c|}{ Annual Room Air Conditioner SR Market Value } \\
\hline & Avg. On-Peak & Avg. Off-Peak & $\begin{array}{l}\text { Avg. Shift- } \\
\text { To Hours }\end{array}$ & $\begin{array}{c}\text { On Peak: From Room Air } \\
\text { Conditioner Load After } \\
100 \% \text { Shifted }\end{array}$ & $\begin{array}{c}\text { Off-Peak: From Room Air } \\
\text { Conditioner Off-Peak Load + } \\
100 \% \text { Load shifted from Peak } \\
\text { to 'Shift To' Hours }\end{array}$ & \begin{tabular}{|c} 
Total Spinning \\
Reserve Cost \\
Savings
\end{tabular} \\
\hline & (\$/MWh) & (\$/MWh) & (\$/MWh) & $(\$ / y r)$ & $(\$ / y r)$ & $(\$ / y r)$ \\
\hline PJM 2006 & $\$ 4.31$ & $\$ 3.54$ & $\$ 3.54$ & $\$ 0.00$ & $\$ 2.45$ & $\$ 2.45$ \\
\hline ERCOT 2008 & $\$ 36.85$ & $\$ 23.76$ & $\$ 23.76$ & $\$ 0.00$ & $\$ 16.47$ & $\$ 16.47$ \\
\hline NYISO 2008 & $\$ 14.84$ & $\$ 8.56$ & $\$ 8.56$ & $\$ 0.00$ & $\$ 5.93$ & $\$ 5.93$ \\
\hline NYISO 2006 & $\$ 12.40$ & $\$ 5.42$ & $\$ 5.42$ & $\$ 0.00$ & $\$ 3.76$ & $\$ 3.76$ \\
\hline CAISO 2008 & $\$ 13.26$ & $\$ 3.56$ & $\$ 3.57$ & $\$ 0.00$ & $\$ 2.47$ & $\$ 2.47$ \\
\hline
\end{tabular}


The additional $6 \%$ optimistic electricity consumption and cost savings resulting from providing energyuse feedback to customers is shown below in Table 4.14 .

Table 4-14. Additional 6\% Savings Resulting from RAC Consumption Feedback to Customers

\begin{tabular}{|r|c|c|}
\hline Market and Year & (kWh/yr) & $\mathbf{( \$ / y r )}$ \\
\hline PJM 2006 & 42 & $\$ 1.98$ \\
\hline ERCOT 2008 & 42 & $\$ 3.88$ \\
\hline NYISO 2008 & 42 & $\$ 4.78$ \\
\hline NYISO 2006 & 42 & $\$ 3.48$ \\
\hline CAISO 2008 & 42 & $\$ 3.52$ \\
\hline
\end{tabular}

Finally, the overall high-end benefits (wholesale cost saving resulting from peak-load shifting, spinning reserves, and consumer feedback combined) are shown in Table 4.15 below.

Table 4-15. Smart RAC Benefit (Peak Load Shift + Spinning Reserves + Feedback Effect)-to-Cost Ratio - Optimistic View

\begin{tabular}{|r|c|c|c|}
\hline & $\begin{array}{c}\text { Grid } \\
\text { Operational } \\
\text { Cost Savings } \\
\text { (Benefits) }\end{array}$ & $\begin{array}{c}\text { Cost of } \\
\text { Additional } \\
\text { Energy } \\
\text { Consumption } \\
\text { at 5\% Credit }\end{array}$ & $\begin{array}{c}\text { Benefits to } \\
\text { Cost Ratio }\end{array}$ \\
\cline { 2 - 4 } Market and Year & $\mathbf{( \$ / y r )}$ & $(\$ / y r)$ & $(-)$ \\
\hline PJM 2006 & $\$ 12.11$ & $\$ 1.65$ & $\mathbf{7 3 3 \%}$ \\
\hline ERCOT 2008 & $\$ 34.28$ & $\$ 3.24$ & $1059 \%$ \\
\hline NYISO 2008 & $\$ 24.00$ & $\$ 3.99$ & $602 \%$ \\
\hline NYISO 2006 & $\$ 20.64$ & $\$ 2.90$ & $\mathbf{7 1 2 \%}$ \\
\hline CAISO 2008 & $\$ 16.24$ & $\$ 2.93$ & $\mathbf{5 5 4 \%}$ \\
\hline
\end{tabular}

Thus, as can be observed from Table 4.15 , the benefit-to-cost ratios overwhelmingly exceed $100 \%$ in all markets.

\subsubsection{Low-End Pessimistic Results}

We first present below in Table 4.16 the annual on-peak and off-peak electricity consumption based on the pessimistic assumptions presented in Section 3.1. 
Table 4-16. RAC On-Peak and Off-Peak Consumption Based on ELCAP Average Summer Day Load Shape and Pessimistic Assumptions

\begin{tabular}{|c|c|c|c|c|c|c|}
\hline \multicolumn{4}{|c|}{ ELCAP (1990) Room Air Conditioner Load Shape } & \multicolumn{3}{|c|}{$\begin{array}{l}2010 \text { Annual Room Air Conditioner On- } \\
\text { Peak and Off-Peak Consumption }\end{array}$} \\
\hline Load Shape: & Average Day & Summer & & Total & Annual On- & Annual Off- \\
\hline & Daily Total & On-Peak & \multirow{4}{*}{$\begin{array}{c}\text { Annual On- } \\
\text { Peak To } \\
\text { Total Ratio }\end{array}$} & Annual & Peak & Peak \\
\hline Start, Hour Ending: & 1 & 14 & & Consumptio & Consumption & Consumption \\
\hline \multirow[t]{3}{*}{ Through Hour Ending: } & 24 & 17 & & n (2010) & (2010) & (2010) \\
\hline & (kWh/day) & (kWh/day) & & (kWh/yr) & $(\mathrm{kWh} / \mathrm{yr})$ & $(\mathrm{kWh} / \mathrm{yr})$ \\
\hline & 5.73 & 1.43 & 0.25 & 693 & 173 & 520 \\
\hline
\end{tabular}

Based on the data shown in Table 4.16, high-end wholesale power production cost savings using smart CDs for peak load shifting are shown below in Table 4.17

Table 4-17. Wholesale Cost Savings from Using Smart RACs for Peak Load Shifting - Pessimistic View

\begin{tabular}{|c|c|c|c|c|c|c|c|}
\hline \multirow[b]{3}{*}{ Market and Year } & \multicolumn{3}{|c|}{ Annual Hourly Energy Market Clearing Prices } & \multicolumn{2}{|c|}{$\begin{array}{l}\text { Annual Energy Cost } \\
\text { (No Load Shift) }\end{array}$} & \multicolumn{2}{|c|}{$\begin{array}{c}\text { Annual Energy Cost Savings from } \\
6 \% \text { Peak Load Shift }\end{array}$} \\
\hline & Avg. On-Peak & Avg. Off-Peak & $\begin{array}{l}\text { Avg. Shift- } \\
\text { To Hours }\end{array}$ & On-Peak & Off-Peak & $\begin{array}{c}\text { On-Peak } \\
\text { Energy Moved } \\
\text { to "Shift To" } \\
\text { Hours }\end{array}$ & Savings \\
\hline & (\$/MWh) & (\$/MWh) & (\$/MWh) & $(\$ / y r)$ & $(\$ / y r)$ & (kWh/yr) & $(\$ / y r)$ \\
\hline PJM 2006 & $\$ 74.45$ & $\$ 41.60$ & $\$ 41.60$ & $\$ 12.91$ & $\$ 21.61$ & 10.84 & $\$ 0.36$ \\
\hline ERCOT 2008 & $\$ 136.50$ & $\$ 80.23$ & $\$ 80.23$ & $\$ 23.67$ & $\$ 41.69$ & 10.84 & $\$ 0.61$ \\
\hline NYISO 2008 & $\$ 164.45$ & $\$ 95.44$ & $\$ 104.01$ & $\$ 28.52$ & $\$ 49.59$ & 10.84 & $\$ 0.66$ \\
\hline NYISO 2006 & $\$ 142.54$ & $\$ 73.03$ & $\$ 73.03$ & $\$ 24.72$ & $\$ 37.94$ & 10.84 & $\$ 0.75$ \\
\hline CAISO 2008 & $\$ 123.28$ & $\$ 73.79$ & $\$ 73.79$ & $\$ 21.38$ & $\$ 38.34$ & 10.84 & $\$ 0.54$ \\
\hline
\end{tabular}

The low-end wholesale cost savings from using smart RACs for providing spinning reserves is shown in Table 4.18 below.

Table 4-18. Wholesale Cost Savings from Using Smart RACs for Spinning Reserves - Pessimistic View

\begin{tabular}{|r|c|c|c|c|c|c|}
\hline & \multicolumn{2}{|c|}{ Annual Hourly SR Market Clearing Prices } & \multicolumn{3}{c|}{ Annual Room Air Conditioner SR Market Value } \\
\cline { 2 - 7 } & Avg. On-Peak & Avg. Off-Peak & $\begin{array}{c}\text { Avg. Shift- } \\
\text { To Hours }\end{array}$ & $\begin{array}{c}\text { On Peak: From Room Air } \\
\text { Conditioner Load After 6\% } \\
\text { Shifted }\end{array}$ & $\begin{array}{c}\text { Off-Peak: From Room Air } \\
\text { Conditioner Off-Peak Load + } \\
\text { 6 Load shifted from Peak to } \\
\text { 'Shift To' Hours }\end{array}$ & $\begin{array}{c}\text { Total Spinning } \\
\text { Reserve Cost } \\
\text { Savings }\end{array}$ \\
\cline { 2 - 8 } Market and Year & $(\$ / \mathrm{MWh})$ & $(\$ / \mathrm{MWh})$ & $(\$ / \mathrm{MWh})$ & $(\$ / \mathrm{yr})$ & $(\$ / \mathrm{yr})$ & $(\$ / \mathrm{yr})$ \\
\hline PJM 2006 & $\$ 4.00$ & $\$ 3.33$ & $\$ 3.33$ & $\$ 0.23$ & $\$ 0.64$ & $\$ 0.87$ \\
\hline ERCOT 2008 & $\$ 37.51$ & $\$ 25.61$ & $\$ 25.54$ & $\$ 2.20$ & $\$ 4.89$ & $\$ 7.09$ \\
\hline NYISO 2008 & $\$ 14.38$ & $\$ 9.56$ & $\$ 9.16$ & $\$ 0.84$ & $\$ 1.82$ & $\$ 2.66$ \\
\hline NYISO 2006 & $\$ 16.02$ & $\$ 5.97$ & $\$ 7.62$ & $\$ 0.94$ & $\$ 1.15$ & $\$ 2.08$ \\
\hline CAISO 2008 & $\$ 14.95$ & $\$ 4.78$ & $\$ 4.30$ & $\$ 0.87$ & $\$ 1$ & $\$ 1.79$ \\
\hline
\end{tabular}


The additional $3 \%$ pessimistic electricity consumption and cost savings resulting from providing energyuse feedback to customers is shown below in Table 4.19.

Table 4-19. Additional 3\% Savings Resulting from RAC Consumption Feedback to Customers

\begin{tabular}{|r|c|c|}
\hline Market and Year & $\mathbf{( k W h / y r )}$ & $\mathbf{( \$ / y r )}$ \\
\hline PJM 2006 & 21 & $\$ 1.04$ \\
\hline ERCOT 2008 & 21 & $\$ 1.96$ \\
\hline NYISO 2008 & 21 & $\$ 2.34$ \\
\hline NYISO 2006 & 21 & $\$ 1.88$ \\
\hline CAISO 2008 & 21 & $\$ 1.79$ \\
\hline
\end{tabular}

Finally, the overall low-end benefits (wholesale cost saving resulting from peak-load shifting, spinning reserves, and consumer feedback combined) are shown in Table 4.20 below.

Table 4-20. Smart RAC Benefit (Peak Load Shift + Spinning Reserves + Feedback Effect)-to-Cost Ratio - Pessimistic View

\begin{tabular}{|r|c|c|c|}
\hline & $\begin{array}{c}\text { Grid } \\
\text { Operational } \\
\text { Cost Savings } \\
\text { (Benefits) }\end{array}$ & $\begin{array}{c}\text { Cost of } \\
\text { Additional } \\
\text { Energy } \\
\text { Consumption } \\
\text { at 5\% Credit }\end{array}$ & $\begin{array}{c}\text { Benefits to } \\
\text { Cost Ratio }\end{array}$ \\
\cline { 2 - 4 } Market and Year & $\mathbf{( \$ / y r )}$ & $\mathbf{( \$ / y r )}$ & $(-)$ \\
\hline PJM 2006 & $\$ 2.26$ & $\$ 1.73$ & $131 \%$ \\
\hline ERCOT 2008 & $\$ 9.66$ & $\$ 3.27$ & $\mathbf{2 9 6 \%}$ \\
\hline NYISO 2008 & $\$ 5.66$ & $\$ 3.91$ & $\mathbf{1 4 5 \%}$ \\
\hline NYISO 2006 & $\$ 4.72$ & $\$ 3.13$ & $\mathbf{1 5 1 \%}$ \\
\hline CAISO 2008 & $\$ 4.11$ & $\$ 2.99$ & $\mathbf{1 3 8 \%}$ \\
\hline
\end{tabular}

Thus, as can be observed from Table 4.20, the benefit-to-cost ratios exceed $100 \%$ even for the pessimistic set of assumptions in all markets.

\subsection{Benefit-to-Cost Ratios: Smart Refrigerators}

In this section, we estimate the benefit-to-cost ratio of smart refrigerators in various markets based on both optimistic and pessimistic sets of assumptions. 


\subsubsection{High-End Optimistic Results}

We first present below in Table 4.21 the refrigerator annual on-peak and off-peak electricity consumption, including the defrost and ice-making splits, based on the optimistic assumptions presented in Section 3.1.

Table 4-21. Refrigerator On-Peak and Off-Peak Consumption Based on ELCAP Average Annual Day Load Shape and Optimistic Assumptions

\begin{tabular}{|c|c|c|c|c|c|c|c|c|c|c|c|c|c|}
\hline \multicolumn{5}{|c|}{ ELCAP (1990) Refrigerator Load Shape } & \multicolumn{9}{|c|}{2010 Annual Refrigerator On-Peak and Off-Peak Consumption } \\
\hline $\begin{array}{l}\text { Start, Hour Ending: } \\
\text { Through Hour Ending: }\end{array}$ & $\begin{array}{c}\text { Average Day } \\
\text { Daily Total } \\
1 \\
24 \\
\text { (kWh/day) } \\
\end{array}$ & \begin{tabular}{|c|} 
Annual \\
On-Peak \\
13 \\
18 \\
(kWh/day) \\
\end{tabular} & $\begin{array}{c}\text { Avg. No. of } \\
\text { On-Peak } \\
\text { Days/Year }\end{array}$ & $\begin{array}{c}\text { Annual On- } \\
\text { Peak To } \\
\text { Total Ratio }\end{array}$ & $\begin{array}{c}\text { Total } \\
\text { Refrigerator } \\
\text { Annual } \\
\text { Consumption } \\
(\mathrm{kWh} / \mathrm{yr}) \\
\end{array}$ & \begin{tabular}{|c|}
$\begin{array}{c}\text { Defrost } \\
\text { Annual } \\
\text { Consumption }\end{array}$ \\
(kWh/yr) \\
\end{tabular} & \begin{tabular}{c|}
$\begin{array}{c}\text { Ice-Making } \\
\text { Annual } \\
\text { Consumption } \\
\text { (kWh/yr) }\end{array}$ \\
\end{tabular} & \begin{tabular}{|c|} 
Annual \\
Refrigerator \\
On-Peak \\
Consumption \\
(kWh/yr) \\
\end{tabular} & \begin{tabular}{|c|} 
Annual \\
Refrigerator Off- \\
Peak \\
Consumption \\
(kWh/yr) \\
\end{tabular} & \begin{tabular}{|c|} 
Annual \\
Defrost On- \\
Peak \\
Consumption \\
(kWh/yr) \\
\end{tabular} & \begin{tabular}{|c|} 
Annual \\
Defrost Off- \\
Peak \\
Consumption \\
(kWh/yr) \\
\end{tabular} & \begin{tabular}{|c|} 
Annual Ice- \\
Making On- \\
Peak \\
Consumption \\
$(\mathrm{kWh} / \mathrm{yr})$ \\
\end{tabular} & $\begin{array}{c}\text { Annual Ice- } \\
\text { Making Off- } \\
\text { Peak } \\
\text { Consumption } \\
\text { (kWh/yr) } \\
\end{array}$ \\
\hline & 4.12 & 1.07 & 365 & 0.26 & 450 & 50 & 84 & 117 & 333 & 13 & 37 & 22 & 62 \\
\hline
\end{tabular}

Based on the data shown in Table 4.21, high-end wholesale power production cost savings using smart refrigerators for peak-load shifting are shown in Table 4.22 below.

Table 4-22. Wholesale Cost Savings from Using Smart Refrigerators for Peak Load Shifting - Optimistic View

\begin{tabular}{|c|c|c|c|c|c|c|c|c|c|c|c|}
\hline \multirow[b]{3}{*}{ Market and Year } & \multicolumn{3}{|c|}{ Annual Hourly Energy Market Clearing Prices } & \multicolumn{2}{|c|}{$\begin{array}{l}\text { Annual Energy Cost } \\
\text { (No Load Shift) }\end{array}$} & \multicolumn{2}{|c|}{$\begin{array}{l}\text { Annual Energy Cost Savings } \\
\text { (from 100\% Defrost Load Shift) }\end{array}$} & \multicolumn{2}{|c|}{$\begin{array}{c}\text { Annual Energy Cost Savings (from } \\
100 \% \text { Ice-Making Load Shift) }\end{array}$} & \multicolumn{2}{|c|}{$\begin{array}{l}\text { Annual Energy Cost Savings } \\
\text { (Total) }\end{array}$} \\
\hline & Avg. On-Peak & Avg. Off-Peak & $\begin{array}{l}\text { Avg. Shift- } \\
\text { To Hours }\end{array}$ & On-Peak & Off-Peak & $\begin{array}{c}\text { On-Peak } \\
\text { Energy Moved } \\
\text { to "Shift To" } \\
\text { Hours }\end{array}$ & Savings & $\begin{array}{c}\text { On-Peak } \\
\text { Energy Moved } \\
\text { to "Shift To" } \\
\text { Hours }\end{array}$ & Savings & $\begin{array}{c}\text { On-Peak } \\
\text { Energy Moved } \\
\text { to "Shift To" } \\
\text { Hours }\end{array}$ & Savings \\
\hline & (\$/MWh) & (\$/MWh) & (\$/MWh) & $(\$ / \mathrm{yr})$ & $(\$ / \mathrm{yr})$ & (kWh/yr) & $(\$ / \mathrm{yr})$ & (kWh/yr) & $(\$ / \mathrm{yr})$ & (kWh/yr) & (\$/yr) \\
\hline PJM 2006 & $\$ 50.64$ & $\$ 39.44$ & $\$ 39.44$ & $\$ 5.94$ & $\$ 13.12$ & 12.90 & $\$ 0.14$ & 21.90 & $\$ 0.25$ & 34.81 & 0.39 \\
\hline ERCOT 2008 & $\$ 105.56$ & $\$ 67.09$ & $\$ 67.09$ & $\$ 12.38$ & $\$ 22.32$ & 12.90 & $\$ 0.50$ & 21.90 & $\$ 0.84$ & 34.81 & 1.34 \\
\hline NYISO 2008 & $\$ 115.97$ & $\$ 92.25$ & $\$ 92.27$ & $\$ 13.60$ & $\$ 30.69$ & 12.90 & $\$ 0.31$ & 21.90 & $\$ 0.52$ & 34.81 & 0.83 \\
\hline NYISO 2006 & $\$ 85.05$ & $\$ 67.44$ & $\$ 67.41$ & $\$ 9.98$ & $\$ 22.44$ & 12.90 & $\$ 0.23$ & 21.90 & $\$ 0.39$ & 34.81 & 0.61 \\
\hline CAISO 2008 & $\$ 82.11$ & $\$ 65.01$ & $\$ 65.02$ & $\$ 9.63$ & $\$ 21.63$ & 12.90 & $\$ 0.22$ & 21.90 & $\$ 0.37$ & 34.81 & 0.60 \\
\hline
\end{tabular}

The high-end wholesale cost savings from using smart refrigerators for providing spinning reserves is shown in Table 4.23 below. 
Table 4-23. Wholesale Cost Savings from Using Smart Refrigerators for Spinning Reserves - Optimistic View

\begin{tabular}{|c|c|c|c|c|c|c|}
\hline \multirow[b]{3}{*}{ Market and Year } & \multicolumn{3}{|c|}{ Annual Hourly Average Market Clearing Prices: SR } & \multicolumn{3}{|c|}{ Annual Refrigerator SR Market Value } \\
\hline & Avg. On-Peak & Avg. Off-Peak & $\begin{array}{l}\text { Avg. Shift- } \\
\text { To Hours }\end{array}$ & $\begin{array}{c}\text { On-Peak: From } \\
\text { Refrigerator Load After } \\
100 \% \text { Defrost and } 100 \% \text { Ice- } \\
\text { Making Shifted }\end{array}$ & $\begin{array}{l}\text { Off-Peak: From Refrigerator } \\
\text { Off-Peak Load + } 100 \% \text { Defrost } \\
\text { and } 100 \% \text { Ice-Making Load } \\
\text { shifted from Peak to 'Shift To' }\end{array}$ & $\begin{array}{l}\text { Total Spinning } \\
\text { Reserve Cost } \\
\text { Savings }\end{array}$ \\
\hline & (\$/MWh) & (\$/MWh) & (\$/MWh) & \begin{tabular}{|c|}
$(\$ / y r)$ \\
\end{tabular} & $(\$ \mathbf{s r})$ & $(\$ / y r)$ \\
\hline PJM 2006 & $\$ 7.29$ & $\$ 8.08$ & $\$ 8.08$ & $\$ 0.60$ & $\$ 2.97$ & $\$ 3.57$ \\
\hline ERCOT 2008 & $\$ 36.85$ & $\$ 23.76$ & $\$ 23.76$ & $\$ 3.04$ & $\$ 8.73$ & $\$ 11.77$ \\
\hline NYISO 2008 & $\$ 14.84$ & $\$ 8.56$ & $\$ 8.56$ & $\$ 1.22$ & $\$ 3.15$ & $\$ 4.37$ \\
\hline NYISO 2006 & $\$ 12.40$ & $\$ 5.42$ & $\$ 5.42$ & $\$ 1.02$ & $\$ 1.99$ & $\$ 3.01$ \\
\hline CAISO 2008 & $\$ 13.26$ & $\$ 3.56$ & $\$ 3.57$ & $\$ 1.09$ & $\$ 1.31$ & $\$ 2.40$ \\
\hline
\end{tabular}

The additional $6 \%$ optimistic electricity consumption and cost savings resulting from providing energyuse feedback to customers is shown below in Table 4.24

Table 4-24. Additional 6\% Savings Resulting from CD Consumption Feedback to Customers

\begin{tabular}{|r|c|c|}
\hline Market and Year & $\mathbf{( k W h / y r )}$ & $\mathbf{( \$ / y r )}$ \\
\hline PJM 2006 & 27 & $\$ 1.14$ \\
\hline ERCOT 2008 & 27 & $\$ 2.08$ \\
\hline NYISO 2008 & 27 & $\$ 2.66$ \\
\hline NYISO 2006 & 27 & $\$ 1.94$ \\
\hline CAISO 2008 & 27 & $\$ 1.88$ \\
\hline
\end{tabular}

Finally, the overall high-end benefits (wholesale cost saving resulting from peak-load shifting, spinning reserves, and consumer feedback combined) are shown in Table 4.25 below.

Table 4-25. Smart Refrigerator Benefit (Peak Load Shift + Spinning Reserves + Feedback Effect)-to-Cost Ratio - Optimistic View

\begin{tabular}{|r|c|c|c|}
\hline \multirow{2}{*}{ Market and Year } & $\begin{array}{c}\text { Grid Operational } \\
\text { Cost Savings }\end{array}$ & $\begin{array}{c}\text { Cost of } \\
\text { Additional }\end{array}$ & $\begin{array}{c}\text { Benefits to } \\
\text { Cost Ratio }\end{array}$ \\
\cline { 2 - 4 } & $\mathbf{( \$ / y r )}$ & $\mathbf{( \$ / y r )}$ & $(-)$ \\
\hline PJM 2006 & $\$ 5.10$ & $\$ 0.95$ & $\mathbf{5 3 6 \%}$ \\
\hline ERCOT 2008 & $\$ 15.19$ & $\$ 1.74$ & $\mathbf{8 7 6 \%}$ \\
\hline NYISO 2008 & $\$ 7.85$ & $\$ 2.21$ & $\mathbf{3 5 5 \%}$ \\
\hline NYISO 2006 & $\$ 5.57$ & $\$ 1.62$ & $\mathbf{3 4 4 \%}$ \\
\hline CAISO 2008 & $\$ 4.87$ & $\$ 1.56$ & $\mathbf{3 1 2 \%}$ \\
\hline
\end{tabular}


Thus, as can be observed from Table 4.25 , the benefit-to-cost ratios overwhelmingly exceed $100 \%$ in all markets.

\subsubsection{Low-End Pessimistic Results}

We first present below in Table 4.26 the annual on-peak and off-peak electricity consumption based on the pessimistic assumptions presented in Section 3.1.

Table 4-26. Refrigerator On-Peak and Off-Peak Consumption Based on ELCAP Average Annual Day Load Shape and Pessimistic Assumptions

\begin{tabular}{|c|c|c|c|c|c|c|c|c|c|c|c|c|c|}
\hline \multicolumn{5}{|c|}{ ELCAP (1990) Refrigerator Load Shape } & \multicolumn{9}{|c|}{2010 Annual Refrigerator On-Peak and Off-Peak Consumption } \\
\hline \multirow[t]{2}{*}{ Load Shape: } & Average Day & Annual & & & \multirow{5}{*}{\begin{tabular}{|c|} 
Total \\
Refrigerator \\
Annual \\
Consumption \\
(kWh/yr) \\
\end{tabular}} & \multirow{5}{*}{$\begin{array}{c}\begin{array}{c}\text { Defrost } \\
\text { Annual } \\
\text { Consumption } \\
\text { (kWh/yr) }\end{array} \\
\end{array}$} & \multirow{5}{*}{$\begin{array}{c}\text { Ice-Making } \\
\text { Annual } \\
\text { Consumption } \\
\text { (kWh/yr) }\end{array}$} & \multirow{5}{*}{$\begin{array}{c}\text { Annual } \\
\text { Refrigerator } \\
\text { On-Peak } \\
\text { Consumption } \\
\text { (kWh/yr) }\end{array}$} & \multirow{5}{*}{\begin{tabular}{|c|} 
Annual \\
Refrigerator Off \\
Peak \\
Consumption \\
(kWh/yr) \\
\end{tabular}} & \multirow{5}{*}{$\begin{array}{c}\text { Annual } \\
\text { Defrost On- } \\
\text { Peak } \\
\text { Consumption } \\
\text { (kWh/yr) } \\
\end{array}$} & \multirow{5}{*}{\begin{tabular}{|c|} 
Annual \\
Defrost Off- \\
Peak \\
Consumption \\
(kWh/yr) \\
\end{tabular}} & \multirow{5}{*}{$\begin{array}{c}\text { Annual Ice- } \\
\text { Making On- } \\
\text { Peak } \\
\text { Consumption } \\
\text { (kWh/yr) }\end{array}$} & \multirow{5}{*}{$\begin{array}{c}\text { Annual Ice- } \\
\text { Making Off- } \\
\text { Peak } \\
\text { Consumptior } \\
\text { (kWh/yr) }\end{array}$} \\
\hline & Daily Total & On-Peak & & & & & & & & & & & \\
\hline Start, Hour Ending: & 1 & 14 & On-Peak & Peak To & & & & & & & & & \\
\hline Through Hour Ending: & 24 & 17 & Days/Year & Total Ratio & & & & & & & & & \\
\hline & (kWh/day) & (kWh/day) & & & & & & & & & & & \\
\hline & 4.12 & 0.70 & 261 & 0.12 & 450 & 50 & 84 & 55 & 395 & 6 & 43 & 10 & 74 \\
\hline
\end{tabular}

Based on the data shown in Table 4.26, high-end wholesale power production cost savings using smart refrigerators for peak load shifting are shown below in Table 4.27.

Table 4-27. Wholesale Cost Savings from Using Smart Refrigerators for Peak Load Shifting Pessimistic View

\begin{tabular}{|c|c|c|c|c|c|c|c|c|c|c|c|}
\hline \multirow[b]{3}{*}{ Market and Year } & \multicolumn{3}{|c|}{ Annual Hourly Energy Market Clearing Prices } & \multicolumn{2}{|c|}{$\begin{array}{l}\text { Annual Energy Cost } \\
\text { (No Load Shift) }\end{array}$} & \multicolumn{2}{|c|}{$\begin{array}{l}\text { Annual Energy Cost Savings } \\
\text { (from } 45 \% \text { Defrost Load Shift) }\end{array}$} & \multicolumn{2}{|c|}{$\begin{array}{l}\text { Annual Energy Cost Savings (from } \\
27 \% \text { Ice-Making Load Shift) }\end{array}$} & \multicolumn{2}{|c|}{$\begin{array}{c}\text { Annual Energy Cost Savings } \\
\text { (Total) }\end{array}$} \\
\hline & Avg. On-Peak & Avg. Off-Peak & $\begin{array}{l}\text { Avg. Shift- } \\
\text { To Hours }\end{array}$ & On-Peak & Off-Peak & $\begin{array}{c}\text { On-Peak } \\
\text { Energy Moved } \\
\text { to "Shift To" } \\
\text { Hours }\end{array}$ & Savings & $\begin{array}{c}\text { On-Peak } \\
\text { Energy Moved } \\
\text { to "Shift To" } \\
\text { Hours }\end{array}$ & Savings & \begin{tabular}{|c|} 
On-Peak \\
Energy Moved \\
to "Shift To" \\
Hours
\end{tabular} & Savings \\
\hline & (\$⿳M十h) & (\$/MWh) & (\$/MWh) & $(\$ / y r)$ & $(\$ / y r)$ & (kWh/yr) & $(\$ / y r)$ & (kWh/yr) & $(\$ / y r)$ & (kWh/yr) & $(\$ / y r)$ \\
\hline PJM 2006 & $\$ 55.55$ & $\$ 40.45$ & $\$ 42.90$ & $\$ 3.06$ & $\$ 15.98$ & 2.72 & $\$ 0.03$ & 2.77 & $\$ 0.04$ & 5.50 & 0.07 \\
\hline ERCOT 2008 & $\$ 119.27$ & $\$ 70.95$ & $\$ 73.03$ & $\$ 6.56$ & $\$ 28.02$ & 2.72 & $\$ 0.13$ & 2.77 & $\$ 0.13$ & 5.50 & 0.25 \\
\hline NYISO 2008 & $\$ 120.56$ & $\$ 95.16$ & $\$ 94.83$ & $\$ 6.63$ & $\$ 37.59$ & 2.72 & $\$ 0.07$ & 2.77 & $\$ 0.07$ & 5.50 & 0.14 \\
\hline NYISO 2006 & $\$ 93.91$ & $\$ 68.87$ & $\$ 72.50$ & $\$ 5.17$ & $\$ 27.20$ & 2.72 & $\$ 0.06$ & 2.77 & $\$ 0.06$ & 5.50 & 0.12 \\
\hline CAISO 2008 & $\$ 88.25$ & $\$ 66.72$ & $\$ 68.67$ & $\$ 4.85$ & $\$ 26.35$ & 2.72 & $\$ 0.05$ & 2.77 & $\$ 0.05$ & 5.50 & 0.11 \\
\hline
\end{tabular}

The low-end wholesale cost savings from using smart refrigerators for providing spinning reserves is shown in Table 4.28 below. 
Table 4-28. Wholesale Cost Savings from Using Smart Refrigerators for Spinning Reserves - Pessimistic View

\begin{tabular}{|c|c|c|c|c|c|c|}
\hline \multirow[b]{3}{*}{ Market and Year } & \multicolumn{3}{|c|}{ Annual Hourly Average Market Clearing Prices: SR } & \multicolumn{3}{|c|}{ Annual Refrigerator SR Market Value } \\
\hline & Avg. On-Peak & Avg. Off-Peak & $\begin{array}{l}\text { Avg. Shift- } \\
\text { To Hours }\end{array}$ & $\begin{array}{l}\text { On-Peak: From } \\
\text { Refrigerator Load After } \\
\text { 45\% Defrost and } 27 \% \text { Ice- } \\
\text { Making Shifted }\end{array}$ & $\begin{array}{l}\text { Off-Peak: From Refrigerator } \\
\text { Off-Peak Load + } 45 \% \text { Defrost } \\
\text { and } 27 \% \text { Ice-Making Load } \\
\text { shifted from Peak to 'Shift To' }\end{array}$ & $\begin{array}{c}\text { Total Spinning } \\
\text { Reserve Cost } \\
\text { Savings }\end{array}$ \\
\hline & (\$/MWh) & (\$/MWh) & (\$/MWh) & $(\$ / y r)$ & (\$/yr) & $(\$ / y r)$ \\
\hline PJM 2006 & $\$ 7.30$ & $\$ 7.96$ & $\$ 8.29$ & $\$ 0.08$ & $\$ 0.72$ & $\$ 0.80$ \\
\hline ERCOT 2008 & $\$ 37.51$ & $\$ 25.61$ & $\$ 25.54$ & $\$ 0.42$ & $\$ 2.31$ & $\$ 2.73$ \\
\hline NYISO 2008 & $\$ 14.38$ & $\$ 9.56$ & $\$ 9.16$ & $\$ 0.16$ & $\$ 0.86$ & $\$ 1.02$ \\
\hline NYISO 2006 & $\$ 16.02$ & $\$ 5.97$ & $\$ 7.62$ & $\$ 0.18$ & $\$ 0.54$ & $\$ 0.72$ \\
\hline CAISO 2008 & $\$ 14.95$ & $\$ 4.78$ & $\$ 4.30$ & $\$ 0.17$ & $\$ 0.43$ & $\$ 0.60$ \\
\hline
\end{tabular}

The additional 3\% pessimistic electricity consumption and cost savings resulting from providing energyuse feedback to customers is shown below in Table 4.29.

Table 4-29. Additional 3\% Savings Resulting from Refrigerator Consumption Feedback to Customers

\begin{tabular}{|r|c|c|}
\hline Market and Year & $\mathbf{( k W h / y r )}$ & $\mathbf{( \$ / y r )}$ \\
\hline PJM 2006 & 14 & $\$ 0.57$ \\
\hline ERCOT 2008 & 14 & $\$ 1.04$ \\
\hline NYISO 2008 & 14 & $\$ 1.33$ \\
\hline NYISO 2006 & 14 & $\$ 0.97$ \\
\hline CAISO 2008 & 14 & $\$ 0.94$ \\
\hline
\end{tabular}

Finally, the overall low-end benefits (wholesale cost saving resulting from peak-load shifting, spinning reserves, and consumer feedback combined) are shown in Table 4.30 below.

Table 4-30. Smart Refrigerator Benefits (Peak Load Shift + Spinning Reserves + Feedback Effect)-toCost Ratio - Pessimistic View

\begin{tabular}{|r|c|c|c|}
\hline \multirow{2}{*}{ Market and Year } & $\begin{array}{c}\text { Grid Operational } \\
\text { Cost Savings }\end{array}$ & $\begin{array}{c}\text { Cost of } \\
\text { Additional }\end{array}$ & $\begin{array}{c}\text { Benefits to } \\
\text { Cost Ratio }\end{array}$ \\
\cline { 2 - 4 } & $\mathbf{( \$ / y r )}$ & $\mathbf{( \$ / y r )}$ & $(-)$ \\
\hline PJM 2006 & $\$ 1.44$ & $\$ 0.95$ & $\mathbf{1 5 1 \%}$ \\
\hline ERCOT 2008 & $\$ 4.02$ & $\$ 1.73$ & $\mathbf{2 3 2 \%}$ \\
\hline NYISO 2008 & $\$ 2.49$ & $\$ 2.21$ & $\mathbf{1 1 3 \%}$ \\
\hline NYISO 2006 & $\$ 1.81$ & $\$ 1.62$ & $\mathbf{1 1 2} \%$ \\
\hline CAISO 2008 & $\$ 1.64$ & $\$ 1.56$ & $105 \%$ \\
\hline
\end{tabular}


Thus, as can be observed from Table 4.30, the benefit-to-cost ratios exceed $100 \%$ even for the pessimistic set of assumptions in all markets.

\subsection{Benefit-to-Cost Ratios: Smart Freezers}

In this section, we estimate the benefit-to-cost ratio of smart freezers in various markets based on both optimistic and pessimistic sets of assumptions.

\subsubsection{High-End Optimistic Results}

We first present below in Table 4.31 the refrigerator annual on-peak and off-peak electricity consumption, including the defrost and ice-making splits, based on the optimistic assumptions presented in Section 3.1.

Table 4-31. Freezer On-Peak and Off-Peak Consumption Based on ELCAP Average Annual Day Load Shape and Optimistic Assumptions

\begin{tabular}{|c|c|c|c|c|c|c|c|c|c|c|c|c|c|}
\hline \multicolumn{5}{|c|}{ ELCAP (1990) Freezer Load Shape } & \multicolumn{9}{|c|}{2010 Annual Freezer On-Peak and Off-Peak Consumption } \\
\hline Load Shape: & Average Day & Annual & & & Total Ereezer I & & Ico-Making & & Annul Freezer & Annual & Annual & Annual Ice- & Annual Ice- \\
\hline & Daily Total & On-Peak & \multirow{4}{*}{$\begin{array}{c}\text { Avg. No. of } \\
\text { On-Peak } \\
\text { Days/Year }\end{array}$} & \multirow{4}{*}{$\begin{array}{c}\text { Annual On- } \\
\text { Peak To } \\
\text { Total Ratio }\end{array}$} & & Annual & Annual & Freezer On- & Off-Peak & Defrost On- & Defrost Off- & Making On- & Making Off- \\
\hline Start, Hour Ending: & 1 & 13 & & & Consumption & Consumption & Consumption & Peak & Consumption & Peak & Peak & Peak & Peak \\
\hline \multirow[t]{3}{*}{ Through Hour Ending: } & 24 & 18 & & & & & & Consumption & & Consumption & Consumption & Consumption & Consumption \\
\hline & (kWh/day) & (kWh/day) & & & (kWh/yr) & (kWh/yr) & (kWh/yr) & (kWh/yr) & $(\mathrm{kWh} / \mathrm{yr})$ & (kWh/yr) & $(\mathrm{kWh} / \mathrm{yr})$ & $(\mathrm{kWh} / \mathrm{yr})$ & $(\mathrm{kWh} / \mathrm{yr})$ \\
\hline & 4.21 & 1.10 & 365 & 0.26 & 423 & 51 & 85 & 111 & 312 & 13 & 37 & 22 & 62 \\
\hline
\end{tabular}

Based on the data shown in Table 4.31, high-end wholesale power production cost savings using smart freezers for peak load shifting are shown in Table 4.32 below.

Table 4-32. Wholesale Cost Savings from Using Smart Freezers for Peak Load Shifting - Optimistic View

\begin{tabular}{|c|c|c|c|c|c|c|c|c|c|c|c|}
\hline \multirow[b]{3}{*}{ Market and Year } & \multicolumn{3}{|c|}{ Annual Hourly Energy Market Clearing Prices } & \multicolumn{2}{|c|}{$\begin{array}{l}\text { Annual Energy Cost } \\
\text { (No Load Shift) }\end{array}$} & \multicolumn{2}{|c|}{$\begin{array}{l}\text { Annual Energy Cost Savings } \\
\text { (from } 100 \% \text { Defrost Load Shift) }\end{array}$} & \multicolumn{2}{|c|}{$\begin{array}{l}\text { Annual Energy Cost Savings (from } \\
100 \% \text { Ice-Making Load Shift) }\end{array}$} & \multicolumn{2}{|c|}{$\begin{array}{c}\text { Annual Energy Cost Savings } \\
\text { (Total) }\end{array}$} \\
\hline & Avg. On-Peak & Avg. Off-Peak & $\begin{array}{l}\text { Avg. Shift- } \\
\text { To Hours }\end{array}$ & On-Peak & Off-Peak & $\begin{array}{c}\text { On-Peak } \\
\text { Energy Moved } \\
\text { to "Shift To" } \\
\text { Hours }\end{array}$ & Savings & $\begin{array}{c}\text { On-Peak } \\
\text { Energy Moved } \\
\text { to "Shift To" } \\
\text { Hours }\end{array}$ & Savings & $\begin{array}{c}\text { On-Peak } \\
\text { Energy Moved } \\
\text { to "Shift To" } \\
\text { Hours }\end{array}$ & Savings \\
\hline & (\$/MWh) & (\$/MWh) & (\$/MWh) & $(\$ / y r)$ & $(\$ / y r)$ & (kWh/yr) & $(\$ / y r)$ & (kWh/yr) & $(\$ / y r)$ & (kWh/yr) & $(\$ / y r)$ \\
\hline PJM 2006 & $\$ 50.64$ & $\$ 39.44$ & $\$ 39.44$ & $\$ 5.61$ & $\$ 12.32$ & 13.29 & $\$ 0.15$ & 22.15 & $\$ 0.25$ & 35.44 & 0.40 \\
\hline ERCOT 2008 & $\$ 105.56$ & $\$ 67.09$ & $\$ 67.09$ & $\$ 11.69$ & $\$ 20.95$ & 13.29 & $\$ 0.51$ & 22.15 & $\$ 0.85$ & 35.44 & 1.36 \\
\hline NYISO 2008 & $\$ 115.97$ & $\$ 92.25$ & $\$ 92.27$ & $\$ 12.84$ & $\$ 28.81$ & 13.29 & $\$ 0.32$ & 22.15 & $\$ 0.53$ & 35.44 & 0.84 \\
\hline NYISO 2006 & $\$ 85.05$ & $\$ 67.44$ & $\$ 67.41$ & $\$ 9.42$ & $\$ 21.06$ & 13.29 & $\$ 0.23$ & 22.15 & $\$ 0.39$ & 35.44 & 0.63 \\
\hline CAISO 2008 & $\$ 82.11$ & $\$ 65.01$ & $\$ 65.02$ & $\$ 9.09$ & $\$ 20.30$ & 13.29 & $\$ 0.23$ & 22.15 & $\$ 0.38$ & 35.44 & 0.61 \\
\hline
\end{tabular}

The high-end wholesale cost savings from using smart freezers for providing spinning reserves is shown in Table 4.33 below. 
Table 4-33. Wholesale Cost Savings from Using Smart Freezers for Spinning Reserves - Optimistic View

\begin{tabular}{|c|c|c|c|c|c|c|}
\hline \multirow[b]{3}{*}{ Market and Year } & \multicolumn{3}{|c|}{ Annual Hourly Average Market Clearing Prices: SR } & \multicolumn{3}{|c|}{ Annual Freezer SR Market Value } \\
\hline & Avg. On-Peak & Avg. Off-Peak & $\begin{array}{l}\text { Avg. Shift- } \\
\text { To Hours }\end{array}$ & $\begin{array}{l}\text { On-Peak: From Freezer } \\
\text { Load After } 100 \% \text { Defrost } \\
\text { and } 100 \% \text { Ice-Making } \\
\text { Shifted }\end{array}$ & $\begin{array}{l}\text { Off-Peak: From Freezer Off- } \\
\text { Peak Load + } 100 \% \text { Defrost and } \\
100 \% \text { Ice-Making Load shifted } \\
\text { from Peak to 'Shift To' Hours }\end{array}$ & $\begin{array}{l}\text { Total Spinning } \\
\text { Reserve Cost } \\
\text { Savings }\end{array}$ \\
\hline & (\$/MWh) & (\$/MWh) & (\$/MWh) & $(\$ / y r)$ & (\$/yr) & (\$/yr) \\
\hline PJM 2006 & $\$ 7.29$ & $\$ 8.08$ & $\$ 8.08$ & $\$ 0.55$ & $\$ 2.81$ & $\$ 3.36$ \\
\hline ERCOT 2008 & $\$ 36.85$ & $\$ 23.76$ & $\$ 23.76$ & $\$ 2.78$ & $\$ 8.26$ & $\$ 11.04$ \\
\hline NYISO 2008 & $\$ 14.84$ & $\$ 8.56$ & $\$ 8.56$ & $\$ 1.12$ & $\$ 2.98$ & $\$ 4.09$ \\
\hline NYISO 2006 & $\$ 12.40$ & $\$ 5.42$ & $\$ 5.42$ & $\$ 0.93$ & $\$ 1.88$ & $\$ 2.82$ \\
\hline CAISO 2008 & $\$ 13.26$ & $\$ 3.56$ & $\$ 3.57$ & $\$ 1.00$ & $\$ 1.24$ & $\$ 2.24$ \\
\hline
\end{tabular}

The additional $6 \%$ optimistic electricity consumption and cost savings resulting from providing energyuse feedback to customers is shown below in Table 4.34 .

Table 4-34. Additional 6\% Savings Resulting from CD Consumption Feedback to Customers

\begin{tabular}{|r|c|c|}
\hline Market and Year & $\mathbf{( k W h / y r )}$ & $\mathbf{( \$ / y r )}$ \\
\hline PJM 2006 & 25 & $\$ 1.08$ \\
\hline ERCOT 2008 & 25 & $\$ 1.96$ \\
\hline NYISO 2008 & 25 & $\$ 2.50$ \\
\hline NYISO 2006 & 25 & $\$ 1.83$ \\
\hline CAISO 2008 & 25 & $\$ 1.76$ \\
\hline
\end{tabular}

Finally, the overall high-end benefits (wholesale cost saving resulting from peak-load shifting, spinning reserves, and consumer feedback combined) are shown in Table 4.35 below. 
Table 4-35. Smart Freezer Benefit (Peak Load Shift + Spinning Reserves + Feedback Effect)-to-Cost Ratio - Optimistic View

\begin{tabular}{|r|c|c|c|}
\hline & $\begin{array}{c}\text { Grid Operational } \\
\text { Cost Savings } \\
\text { (Benefits) }\end{array}$ & $\begin{array}{c}\text { Cost of } \\
\text { Additional } \\
\text { Energy } \\
\text { Consumption } \\
\text { at 5\% Credit }\end{array}$ & $\begin{array}{c}\text { Benefits to } \\
\text { Cost Ratio }\end{array}$ \\
\hline Market and Year & $\mathbf{( \$ / y r )}$ & $\mathbf{( \$ / y r )}$ & $(-)$ \\
\hline PJM 2006 & $\$ 4.83$ & $\$ 0.90$ & $\mathbf{5 3 9 \%}$ \\
\hline ERCOT 2008 & $\$ 14.36$ & $\$ 1.63$ & $\mathbf{8 8 0 \%}$ \\
\hline NYISO 2008 & $\$ 7.43$ & $\$ 2.08$ & $\mathbf{3 5 7 \%}$ \\
\hline NYISO 2006 & $\$ 5.27$ & $\$ 1.52$ & $\mathbf{3 4 6 \%}$ \\
\hline CAISO 2008 & $\$ 4.61$ & $\$ 1.47$ & $\mathbf{3 1 4 \%}$ \\
\hline
\end{tabular}

Thus, as can be observed from Table 4.35 , the benefit-to-cost ratios overwhelmingly exceed $100 \%$ in all markets.

\subsubsection{Low-End Pessimistic Results}

We first present below in Table 4.36, the annual on-peak and off-peak electricity consumption based on the pessimistic assumptions presented in Section 3.1.

Table 4-36. Freezer On-Peak and Off-Peak Consumption Based on ELCAP Average Annual Day Load Shape and Pessimistic Assumptions

\begin{tabular}{|c|c|c|c|c|c|c|c|c|c|c|c|c|c|}
\hline \multicolumn{5}{|c|}{ ELCAP (1990) Refrigerator Load Shape } & \multicolumn{9}{|c|}{2010 Annual Refrigerator On-Peak and Off-Peak Consumption } \\
\hline Load Shape: & Average Day & Annual & & & \multirow{4}{*}{$\begin{array}{c}\text { Total } \\
\text { Refrigerator } \\
\text { Annual } \\
\text { Consumption } \\
\text { (kWh/yr) } \\
\end{array}$} & \multirow{4}{*}{\begin{tabular}{|c|}
$\begin{array}{c}\text { Defrost } \\
\text { Annual } \\
\text { Consumption } \\
\text { (kWh/yr) }\end{array}$ \\
\end{tabular}} & \multirow{4}{*}{\begin{tabular}{|c|}
$\begin{array}{c}\text { Ice-Making } \\
\text { Annual } \\
\text { Consumption } \\
(\mathrm{kWh} / \mathrm{yr})\end{array}$ \\
\end{tabular}} & \multirow{4}{*}{\begin{tabular}{|c|} 
Annual \\
Refrigerator \\
On-Peak \\
Consumption \\
(kWh/yr) \\
\end{tabular}} & \multirow{4}{*}{\begin{tabular}{|c|} 
Annual \\
Refrigerator off \\
Peak \\
Consumption \\
$(\mathrm{kWh} / \mathrm{yr})$
\end{tabular}} & \multirow{4}{*}{\begin{tabular}{|c|} 
Annual \\
Defrost On- \\
Peak \\
Consumption \\
(kWh/yr) \\
\end{tabular}} & \multirow{4}{*}{$\begin{array}{c}\text { Annual } \\
\text { Defrost Off- } \\
\text { Peak } \\
\text { Consumption } \\
\text { (kWh/yr) }\end{array}$} & \multirow{4}{*}{$\begin{array}{c}\text { Annual Ice- } \\
\text { Making On- } \\
\text { Peak } \\
\text { Consumption } \\
\text { (kWh/yr) }\end{array}$} & \multirow{4}{*}{\begin{tabular}{|} 
Annual Ice- \\
Making Off- \\
Peak \\
Consumption \\
(kWh/yr)
\end{tabular}} \\
\hline & Daily Total & On-Peak & \multirow{3}{*}{$\begin{array}{c}\text { Avg. No. of } \\
\text { On-Peak } \\
\text { Days/Year }\end{array}$} & \multirow{3}{*}{$\begin{array}{c}\text { Annual On- } \\
\text { Peak To } \\
\text { Total Ratio }\end{array}$} & & & & & & & & & \\
\hline Start, Hour Ending: & 1 & 14 & & & & & & & & & & & \\
\hline Through Hour Ending: & 24 & 17 & & & & & & & & & & & \\
\hline & 4.12 & 0.70 & 261 & 0.12 & \begin{tabular}{l|l}
450 & 1 \\
\end{tabular} & 50 & 84 & 55 & 395 & 6 & \begin{tabular}{|c|}
43 \\
\end{tabular} & 10 & 74 \\
\hline
\end{tabular}

Based on the data shown in Table 4.36, high-end wholesale power production cost savings using smart freezers for peak load shifting are shown below in Table 4.37. 
Table 4-37. Wholesale Cost Savings from Using Smart Freezers for Peak Load Shifting - Pessimistic View

\begin{tabular}{|c|c|c|c|c|c|c|c|c|c|c|c|}
\hline \multirow[b]{3}{*}{ Market and Year } & \multicolumn{3}{|c|}{ Annual Hourly Energy Market Clearing Prices } & \multicolumn{2}{|c|}{$\begin{array}{l}\text { Annual Energy Cost } \\
\text { (No Load Shift) }\end{array}$} & \multicolumn{2}{|c|}{$\begin{array}{l}\text { Annual Energy Cost Savings } \\
\text { (from 45\% Defrost Load Shift) }\end{array}$} & \multicolumn{2}{|c|}{$\begin{array}{c}\text { Annual Energy Cost Savings (from } \\
27 \% \text { Ice-Making Load Shift) }\end{array}$} & \multicolumn{2}{|c|}{$\begin{array}{l}\text { Annual Energy Cost Savings } \\
\text { (Total) }\end{array}$} \\
\hline & Avg. On-Peak & Avg. Off-Peak & $\begin{array}{l}\text { Avg. Shift- } \\
\text { To Hours }\end{array}$ & On-Peak & Off-Peak & $\begin{array}{c}\text { On-Peak } \\
\text { Energy Moved } \\
\text { to "Shift To" } \\
\text { Hours }\end{array}$ & Savings & $\begin{array}{c}\text { On-Peak } \\
\text { Energy Moved } \\
\text { to "Shift To" } \\
\text { Hours }\end{array}$ & Savings & $\begin{array}{c}\text { On-Peak } \\
\text { Energy Moved } \\
\text { to "Shift To" } \\
\text { Hours }\end{array}$ & Savings \\
\hline & (\$/MWh) & (\$/MWh) & (\$/MWh) & $(\$ / y r)$ & $(\$ / y r)$ & (kWh/yr) & $(\$ / y r)$ & (kWh/yr) & $(\$ / y r)$ & (kWh/yr) & $(\$ / y r)$ \\
\hline PJM 2006 & $\$ 55.55$ & $\$ 40.45$ & $\$ 42.90$ & $\$ 3.06$ & $\$ 15.98$ & 2.72 & $\$ 0.03$ & 2.77 & $\$ 0.04$ & 5.50 & 0.07 \\
\hline ERCOT 2008 & $\$ 119.27$ & $\$ 70.95$ & $\$ 73.03$ & $\$ 6.56$ & $\$ 28.02$ & 2.72 & $\$ 0.13$ & 2.77 & $\$ 0.13$ & 5.50 & 0.25 \\
\hline NYISO 2008 & $\$ 120.56$ & $\$ 95.16$ & $\$ 94.83$ & $\$ 6.63$ & $\$ 37.59$ & 2.72 & $\$ 0.07$ & 2.77 & $\$ 0.07$ & 5.50 & 0.14 \\
\hline NYISO 2006 & $\$ 93.91$ & $\$ 68.87$ & $\$ 72.50$ & $\$ 5.17$ & $\$ 27.20$ & 2.72 & $\$ 0.06$ & 2.77 & $\$ 0.06$ & 5.50 & 0.12 \\
\hline CAISO 2008 & $\$ 88.25$ & $\$ 66.72$ & $\$ 68.67$ & $\$ 4.85$ & $\$ 26.35$ & 2.72 & $\$ 0.05$ & 2.77 & $\$ 0.05$ & 5.50 & 0.11 \\
\hline
\end{tabular}

The low-end wholesale cost savings from using smart freezers for providing spinning reserves is shown in Table 4.38 below.

Table 4-38. Wholesale Cost Savings from Using Smart Freezers for Spinning Reserves - Pessimistic View

\begin{tabular}{|c|c|c|c|c|c|c|}
\hline \multirow[b]{3}{*}{ Market and Year } & \multicolumn{3}{|c|}{ Annual Hourly Average Market Clearing Prices: SR } & \multicolumn{3}{|c|}{ Annual Freezer SR Market Value } \\
\hline & Avg. On-Peak & Avg. Off-Peak & $\begin{array}{l}\text { Avg. Shift- } \\
\text { To Hours }\end{array}$ & $\begin{array}{l}\text { On-Peak: From Freezer } \\
\text { Load After 45\% Defrost and } \\
\text { 27\% Ice-Making Shifted }\end{array}$ & $\begin{array}{l}\text { Off-Peak: From Freezer Off- } \\
\text { Peak Load }+45 \% \text { Defrost and } \\
27 \% \text { Ice-Making Load shifted } \\
\text { from Peak to 'Shift To' Hours }\end{array}$ & $\begin{array}{l}\text { Total Spinning } \\
\text { Reserve Cost } \\
\text { Savings }\end{array}$ \\
\hline & (\$/MWh) & (\$/MWh) & (\$/MWh) & $(\$ / y r)$ & $(\$ / y r)$ & $(\$ / y r)$ \\
\hline PJM 2006 & $\$ 7.30$ & $\$ 7.96$ & $\$ 8.29$ & $\$ 0.08$ & $\$ 0.67$ & $\$ 0.75$ \\
\hline ERCOT 2008 & $\$ 37.51$ & $\$ 25.61$ & $\$ 25.54$ & $\$ 0.40$ & $\$ 2.17$ & $\$ 2.56$ \\
\hline NYISO 2008 & $\$ 14.38$ & $\$ 9.56$ & $\$ 9.16$ & $\$ 0.15$ & $\$ 0.81$ & $\$ 0.96$ \\
\hline NYISO 2006 & $\$ 16.02$ & $\$ 5.97$ & $\$ 7.62$ & $\$ 0.17$ & $\$ 0.51$ & $\$ 0.68$ \\
\hline CAISO 2008 & $\$ 14.95$ & $\$ 4.78$ & $\$ 4.30$ & $\$ 0.16$ & $\$ 0.40$ & $\$ 0.56$ \\
\hline
\end{tabular}

The additional 3\% pessimistic electricity consumption and cost savings resulting from providing energyuse feedback to customers is shown below in Table 4.39.

Table 4-39. Additional 3\% Savings Resulting from Freezer Consumption Feedback to Customers

\begin{tabular}{|r|c|c|}
\hline Market and Year & $\mathbf{( k W h / y r )}$ & $\mathbf{( \$ / y r )}$ \\
\hline PJM 2006 & 13 & $\$ 0.54$ \\
\hline ERCOT 2008 & 13 & $\$ 0.98$ \\
\hline NYISO 2008 & 13 & $\$ 1.25$ \\
\hline NYISO 2006 & 13 & $\$ 0.91$ \\
\hline CAISO 2008 & 13 & $\$ 0.88$ \\
\hline
\end{tabular}


Finally, the overall low-end benefits (wholesale cost saving resulting from peak-load shifting, spinning reserves, and consumer feedback combined) are shown in Table 4.40 below.

Table 4-40. Smart Freezer Benefits (Peak Load Shift + Spinning Reserves + Feedback Effect)-to-Cost Ratio - Pessimistic View

\begin{tabular}{|r|c|c|c|}
\hline & $\begin{array}{c}\text { Grid Operational } \\
\text { Cost Savings } \\
\text { (Benefits) }\end{array}$ & $\begin{array}{c}\text { Cost of } \\
\text { Additional } \\
\text { Energy } \\
\text { Consumption } \\
\text { at 5\% Credit }\end{array}$ & $\begin{array}{c}\text { Benefits to } \\
\text { Cost Ratio }\end{array}$ \\
\hline Market and Year & $\mathbf{( \$ / y r )}$ & $\mathbf{( \$ / y r )}$ & $(-)$ \\
\hline PJM 2006 & $\$ 1.36$ & $\$ 0.90$ & $\mathbf{1 5 2 \%}$ \\
\hline ERCOT 2008 & $\$ 3.80$ & $\$ 1.63$ & $\mathbf{2 3 4 \%}$ \\
\hline NYISO 2008 & $\$ 2.35$ & $\$ 2.08$ & $\mathbf{1 1 3 \%}$ \\
\hline NYISO 2006 & $\$ 1.71$ & $\$ 1.52$ & $\mathbf{1 1 2 \%}$ \\
\hline CAISO 2008 & $\$ 1.55$ & $\$ 1.47$ & $\mathbf{1 0 6 \%}$ \\
\hline
\end{tabular}

Thus, as can be observed from Table 4.40, the benefits to cost ratios exceed $100 \%$ even for the pessimistic set of assumptions in all markets.

\subsection{Benefit-to-Cost Ratios: Smart Clothes Washers (CWs)}

In this section, we estimate the benefit-to-cost ratio of smart CWs in various markets based on both optimistic and pessimistic sets of assumptions.

\subsubsection{High-End Optimistic Results}

We first present below in Table 4.41 the $\mathrm{CW}$ annual on-peak and off-peak electricity consumption, including the $\mathrm{CW}$ machine and $\mathrm{CW}$ hot water splits, based on the optimistic assumptions presented in Section 3.1.

Table 4-41. CW On-Peak and Off-Peak Consumption Based on ELCAP Average Annual Day Load Shape and Optimistic Assumptions

\begin{tabular}{|c|c|c|c|c|c|c|c|c|c|c|c|}
\hline \multicolumn{5}{|c|}{ ELCAP (1990) Clothes Washer Load Shape } & \multicolumn{7}{|c|}{2010 Annual Clothes Washer On-Peak and Off-Peak Consumption } \\
\hline Load Shape: & Average Day & Annual & & & \multirow[b]{2}{*}{$\begin{array}{c}\text { Total Annual } \\
\text { Consumption } \\
\text { (Machine + Hot } \\
\text { Water) }\end{array}$} & \multirow[b]{2}{*}{$\begin{array}{c}\text { Total Annual } \\
\text { Consumption } \\
\text { (Machine Only) }\end{array}$} & \multirow[b]{2}{*}{$\begin{array}{c}\text { Total Annual } \\
\text { Consumption } \\
\text { (Hot Water } \\
\text { Only) }\end{array}$} & \multirow[b]{2}{*}{$\begin{array}{c}\text { Annual On- } \\
\text { Peak } \\
\text { Consumption } \\
\text { (Machine } \\
\text { Only) }\end{array}$} & \multirow[b]{2}{*}{\begin{tabular}{|c|} 
Annual Off- \\
Peak \\
Consumption \\
(Machine \\
Only)
\end{tabular}} & \multirow[b]{2}{*}{$\begin{array}{l}\text { Annual On- } \\
\text { Peak } \\
\text { Consumption } \\
\text { (Hot Water } \\
\text { Only) }\end{array}$} & \multirow[b]{2}{*}{$\begin{array}{c}\text { Annual Off- } \\
\text { Peak } \\
\text { Consumption } \\
\text { (Hot Water } \\
\text { Only) }\end{array}$} \\
\hline Start, Hour Ending: & \begin{tabular}{|c|} 
Daily Total \\
1
\end{tabular} & $\begin{array}{c}\text { On-Peak } \\
13\end{array}$ & $\begin{array}{c}\text { Avg. No. of } \\
\text { On-Peak } \\
\text { Days/Year }\end{array}$ & $\begin{array}{c}\text { Annual On- } \\
\text { Peak To } \\
\text { Total Ratio }\end{array}$ & & & & & & & \\
\hline & (kWh/day) & (kWh/day) & & & $(\mathrm{kWh} / \mathrm{yr})$ & (kWh/yr) & (kWh/yr) & (kWh/yr) & $(\mathrm{kWh} / \mathrm{yr})$ & $(\mathrm{kWh} / \mathrm{yr})$ & (kWh/yr) \\
\hline & 0.29 & 0.10 & 365 & 0.34 & 209 & 105 & 105 & 35 & 69 & 35 & 69 \\
\hline
\end{tabular}

Based on the data shown in Table 4.41, high-end wholesale power production cost savings using smart CWs for peak load shifting are shown in Table 4.42 below. Note: as explained in Section 3.1.2.5, a 
CW's annual electricity consumption is split between CW machine-only consumption, and CW waterheater consumption. This split has a bearing on how peak-load-shift savings are evaluated. When $\mathrm{CW}$ consumption is shifted, it follows that both $\mathrm{CW}$ machine and $\mathrm{CW}$ water-heater consumption shift.

However, only those CWs that are based on electricity-powered water heaters contribute to the savings resulting from peak-load shifting; the gas-fired water heaters do not contribute to the savings. We take this factor into account in estimating the CW savings shown in Table 4.42 below.

Table 4-42. Wholesale Cost Savings from Using Smart CWs for Peak Load Shifting - Optimistic View

\begin{tabular}{|c|c|c|c|c|c|c|c|}
\hline \multirow[b]{3}{*}{ Market and Year } & \multicolumn{3}{|c|}{ Annual Hourly Energy Market Clearing Prices } & \multicolumn{2}{|c|}{$\begin{array}{l}\text { Annual Energy Cost } \\
\text { (No Load Shift) }\end{array}$} & \multicolumn{2}{|c|}{$\begin{array}{l}\text { Annual Energy Cost Savings from } \\
100 \% \text { Peak Load Shift }\end{array}$} \\
\hline & $\begin{array}{l}\text { Avg. On- } \\
\text { Peak }\end{array}$ & Avg. Off-Peak & $\begin{array}{c}\text { Avg. Shift-To } \\
\text { Hours }\end{array}$ & On-Peak & Off-Peak & $\begin{array}{c}\text { On-Peak } \\
\text { Energy Moved } \\
\text { to "Shift To" } \\
\text { Hours }\end{array}$ & Savings \\
\hline & (\$/MWh) & (\$/MWh) & (\$/MWh) & (\$/yr) & $(\$ / y r)$ & (kWh/yr) & $(\$ / y r)$ \\
\hline PJM 2006 & $\$ 50.64$ & $\$ 39.44$ & $\$ 39.44$ & $\$ 2.52$ & $\$ 3.81$ & 49.69 & $\$ 0.56$ \\
\hline ERCOT 2008 & $\$ 105.56$ & $\$ 67.09$ & $\$ 67.09$ & $\$ 5.25$ & $\$ 6.48$ & 49.69 & $\$ 1.91$ \\
\hline NYISO 2008 & $\$ 115.97$ & $\$ 92.25$ & $\$ 92.27$ & $\$ 5.76$ & $\$ 8.91$ & 49.69 & $\$ 1.18$ \\
\hline NYISO 2006 & $\$ 85.05$ & $\$ 67.44$ & $\$ 67.41$ & $\$ 4.23$ & $\$ 6.52$ & 49.69 & $\$ 0.88$ \\
\hline CAISO 2008 & $\$ 82.11$ & $\$ 65.01$ & $\$ 65.02$ & $\$ 4.08$ & $\$ 6.28$ & 49.69 & $\$ 0.85$ \\
\hline
\end{tabular}

The high-end wholesale cost savings from using smart CWs for providing spinning reserves is shown in Table 4.43 below. Note: as was the case with peak-load shifting, we take into account the split in CW electricity consumption between $\mathrm{CW}$ machine usage and $\mathrm{CW}$ water heater usage. Furthermore, any $\mathrm{CW}$ spinning-reserves value comes only from $\mathrm{CW}$ machine consumption, because a temporary curtailment of $\mathrm{CW}$ operation does not mean that water heater operation is curtailed. The water heater is a separate appliance, and it will not turn off for say 10 minutes in response to a contingency signal to the CW. (Of course, a smart water heater might itself provide spinning reserves, but that is distinct from the spinning reserve value of a $\mathrm{CW}$ ). This factor is taken into account in estimating $\mathrm{CW}$ spinning-reserve value as shown in Table 4.43 below.

Table 4-43. Wholesale Cost Savings from Using Smart CWs for Spinning Reserves - Optimistic View

\begin{tabular}{|c|c|c|c|c|c|c|}
\hline \multirow[b]{3}{*}{ Market and Year } & \multicolumn{3}{|c|}{ Annual Hourly SR Market Clearing Prices } & \multicolumn{3}{|c|}{ Annual Clothes Washer (Machine Only) SR Market Value } \\
\hline & $\begin{array}{l}\text { Avg. On- } \\
\text { Peak }\end{array}$ & Avg. Off-Peak & $\begin{array}{l}\text { Avg. Shift-To } \\
\text { Hours }\end{array}$ & $\begin{array}{l}\text { On Peak: From Clothes } \\
\text { Washer Load After } 100 \% \\
\text { Shifted }\end{array}$ & $\begin{array}{c}\text { Off-Peak: From Clothes Washer } \\
\text { Off-Peak Load + } 100 \% \text { Load } \\
\text { shifted from Peak to 'Shift To' } \\
\text { Hours } \\
\end{array}$ & \begin{tabular}{|} 
Total Spinning \\
Reserve Cost \\
Savings
\end{tabular} \\
\hline & (\$/MWh) & (\$/MWh) & (\$/MWh) & (\$/yr) & $(\$ / y r)$ & $(\$ / y r)$ \\
\hline PJM 2006 & $\$ 7.29$ & $\$ 8.08$ & $\$ 8.08$ & $\$ 0.00$ & $\$ 0.84$ & $\$ 0.84$ \\
\hline ERCOT 2008 & $\$ 36.85$ & $\$ 23.76$ & $\$ 23.76$ & $\$ 0.00$ & $\$ 2.48$ & $\$ 2.48$ \\
\hline NYISO 2008 & $\$ 14.84$ & $\$ 8.56$ & $\$ 8.56$ & $\$ 0.00$ & $\$ 0.89$ & $\$ 0.89$ \\
\hline NYISO 2006 & $\$ 12.40$ & $\$ 5.42$ & $\$ 5.42$ & $\$ 0.00$ & $\$ 0.57$ & $\$ 0.57$ \\
\hline CAISO 2008 & $\$ 13.26$ & $\$ 3.56$ & $\$ 3.57$ & $\$ 0.00$ & $\$ 0.37$ & $\$ 0.37$ \\
\hline
\end{tabular}


The additional $6 \%$ optimistic electricity consumption and cost savings resulting from providing energyuse feedback to customers is shown below in Table 4.44 .

Table 4-44. Additional 6\% Savings Resulting from CW Consumption Feedback to Customers

\begin{tabular}{|r|c|c|}
\hline Market and Year & $\mathbf{( k W h / y r )}$ & $\mathbf{( \$ / y r )}$ \\
\hline PJM 2006 & 9 & $\$ 0.38$ \\
\hline ERCOT 2008 & 9 & $\$ 0.70$ \\
\hline NYISO 2008 & 9 & $\$ 0.88$ \\
\hline NYISO 2006 & 9 & $\$ 0.64$ \\
\hline CAISO 2008 & 9 & $\$ 0.62$ \\
\hline
\end{tabular}

Finally, the overall high-end benefits (wholesale cost saving resulting from peak-load shifting, spinning reserves, and consumer feedback combined) are shown in Table 4.45 below.

Table 4-45. Smart CW Benefit (Peak Load Shift + Spinning Reserves + Feedback Effect)-to-Cost Ratio - Optimistic View

\begin{tabular}{|r|c|c|c|}
\hline & $\begin{array}{c}\text { Grid } \\
\text { Operational } \\
\text { Cost Savings } \\
\text { (Benefits) }\end{array}$ & $\begin{array}{c}\text { Cost of } \\
\text { Additional } \\
\text { Energy } \\
\text { Consumption } \\
\text { at 5\% Credit }\end{array}$ & $\begin{array}{c}\text { Benefits to } \\
\text { Cost Ratio }\end{array}$ \\
\cline { 2 - 4 } Market and Year & $\mathbf{( \$ / y r )}$ & $\mathbf{( \$ / y r )}$ & $(-)$ \\
\hline PJM 2006 & $\$ 1.78$ & $\$ 0.32$ & $\mathbf{5 6 3 \%}$ \\
\hline ERCOT 2008 & $\$ 5.10$ & $\$ 0.32$ & $\mathbf{1 6 1 2 \%}$ \\
\hline NYISO 2008 & $\$ 2.95$ & $\$ 0.32$ & $\mathbf{9 3 4 \%}$ \\
\hline NYISO 2006 & $\$ 2.09$ & $\$ 0.32$ & $\mathbf{6 6 0 \%}$ \\
\hline CAISO 2008 & $\$ 1.84$ & $\$ 0.32$ & $\mathbf{5 8 3 \%}$ \\
\hline & & & \\
\hline
\end{tabular}

Thus, as can be observed from Table 4.45 , the benefit-to-cost ratios overwhelmingly exceed $100 \%$ in all markets.

\subsubsection{Low-End Pessimistic Results}

We first present below in Table 4.46 the annual on-peak and off-peak electricity consumption, including the $\mathrm{CW}$ machine and $\mathrm{CW}$ water heater splits, based on the pessimistic assumptions presented in Section 3.1. 
Table 4-46. CW On-Peak and Off-Peak Consumption Based on ELCAP Average Annual Day Load Shape and Pessimistic Assumptions

\begin{tabular}{|c|c|c|c|c|c|c|c|c|c|c|c|}
\hline \multicolumn{5}{|c|}{ ELCAP (1990) Clothes Washer Load Shape } & \multicolumn{7}{|c|}{2010 Annual Clothes Washer On-Peak and Off-Peak Consumption } \\
\hline Load Shape: & Average Day & Annual & & & \multirow[b]{2}{*}{$\begin{array}{c}\text { Total Annual } \\
\text { Consumption } \\
\text { (Machine + Hot } \\
\text { Water) }\end{array}$} & \multirow[b]{2}{*}{$\begin{array}{c}\text { Total Annual } \\
\text { Consumption } \\
\text { (Machine Only) }\end{array}$} & \multirow[b]{2}{*}{$\begin{array}{c}\text { Total Annual } \\
\text { Consumption } \\
\text { (Hot Water } \\
\text { Only) }\end{array}$} & \multirow[b]{2}{*}{$\begin{array}{l}\text { Annual On- } \\
\text { Peak } \\
\text { Consumption } \\
\text { (Machine } \\
\text { Only) }\end{array}$} & \multirow[b]{2}{*}{\begin{tabular}{|c} 
Annual Off- \\
Peak \\
Consumption \\
(Machine \\
Only)
\end{tabular}} & \multirow[b]{2}{*}{$\begin{array}{l}\text { Annual On- } \\
\text { Peak } \\
\text { Consumption } \\
\text { (Hot Water } \\
\text { Only) }\end{array}$} & \multirow[b]{2}{*}{\begin{tabular}{|c} 
Annual Off- \\
Peak \\
Consumption \\
(Hot Water \\
Only)
\end{tabular}} \\
\hline Through Hour Ending: & $\begin{array}{c}\text { Daily Total } \\
1\end{array}$ & $\begin{array}{c}\text { On-Peak } \\
14\end{array}$ & $\begin{array}{c}\text { Avg. No. of } \\
\text { On-Peak } \\
\text { Days/Year }\end{array}$ & $\begin{array}{c}\text { Annual On- } \\
\text { Peak To } \\
\text { Total Ratio }\end{array}$ & & & & & & & \\
\hline & (kWh/day) & (kWh/day) & & & (kWh/yr) & (kWh/yr) & (kWh/yr) & (kWh/yr) & (kWh/yr) & (kWh/yr) & (kWh/yr) \\
\hline & 0.29 & 0.06 & 261 & 0.15 & 209 & 105 & 105 & 16 & 88 & 16 & 88 \\
\hline
\end{tabular}

Based on the data shown in Table 4.46, high-end wholesale power production cost savings using smart CWs for peak-load shifting are shown below in Table 4.47. As was the case with the high-end savings shown in Table 4.42, we take into account the effect that splitting consumption between $\mathrm{CW}$ machine and $\mathrm{CW}$ water heating has on the savings.

Table 4-47. Wholesale Cost Savings from Using Smart CWs for Peak Load Shifting - Pessimistic View

\begin{tabular}{|c|c|c|c|c|c|c|c|}
\hline \multirow[b]{3}{*}{ Market and Year } & \multicolumn{3}{|c|}{ Annual Hourly Energy Market Clearing Prices } & \multicolumn{2}{|c|}{$\begin{array}{l}\text { Annual Energy Cost } \\
\text { (No Load Shift) }\end{array}$} & \multicolumn{2}{|c|}{$\begin{array}{c}\text { Annual Energy Cost Savings from } \\
18 \% \text { Peak Load Shift }\end{array}$} \\
\hline & $\begin{array}{l}\text { Avg. On- } \\
\text { Peak }\end{array}$ & Avg. Off-Peak & $\begin{array}{c}\text { Avg. Shift-To } \\
\text { Hours }\end{array}$ & On-Peak & Off-Peak & $\begin{array}{c}\text { On-Peak } \\
\text { Energy Moved } \\
\text { to "Shift To" } \\
\text { Hours }\end{array}$ & Savings \\
\hline & (\$/MWh) & (\$/MWh) & (\$/MWh) & $(\$ / y r)$ & (\$/yr) & (kWh/yr) & (\$/yr) \\
\hline PJM 2006 & $\$ 55.55$ & $\$ 40.45$ & $\$ 42.90$ & $\$ 1.26$ & $\$ 5.00$ & 3.96 & $\$ 0.05$ \\
\hline ERCOT 2008 & $\$ 119.27$ & $\$ 70.95$ & $\$ 73.03$ & $\$ 2.70$ & $\$ 8.77$ & 3.96 & $\$ 0.18$ \\
\hline NYISO 2008 & $\$ 120.56$ & $\$ 95.16$ & $\$ 94.83$ & $\$ 2.73$ & $\$ 11.77$ & 3.96 & $\$ 0.10$ \\
\hline NYISO 2006 & $\$ 93.91$ & $\$ 68.87$ & $\$ 72.50$ & $\$ 2.13$ & $\$ 8.52$ & 3.96 & $\$ 0.08$ \\
\hline CAISO 2008 & $\$ 88.25$ & $\$ 66.72$ & $\$ 68.67$ & $\$ 2.00$ & $\$ 8.25$ & 3.96 & $\$ 0.08$ \\
\hline
\end{tabular}

The low-end wholesale cost savings from using smart CWs for providing spinning reserves is shown in Table 4.48 below. As was the case with the high-end savings shown in Table 4.43, we take into account the effect that splitting consumption between $\mathrm{CW}$ machine and $\mathrm{CW}$ water heating has on the savings.

Table 4-48. Wholesale Cost Savings from Using Smart CWs for Spinning Reserves - Pessimistic View

\begin{tabular}{|c|c|c|c|c|c|c|}
\hline \multirow[b]{3}{*}{ Market and Year } & \multicolumn{3}{|c|}{ Annual Hourly SR Market Clearing Prices } & \multicolumn{3}{|c|}{ Annual Clothes Washer (Machine Only) SR Market Value } \\
\hline & $\begin{array}{l}\text { Avg. On- } \\
\text { Peak }\end{array}$ & Avg. Off-Peak & $\begin{array}{l}\text { Avg. Shift-To } \\
\text { Hours }\end{array}$ & $\begin{array}{l}\text { On Peak: From Clothes } \\
\text { Washer Load After 18\% } \\
\text { Shifted }\end{array}$ & \begin{tabular}{|c|} 
Off-Peak: From Clothes Washer \\
Off-Peak Load + $18 \%$ Load \\
shifted from Peak to 'Shift To' \\
Hours
\end{tabular} & $\begin{array}{l}\text { Total Spinning } \\
\text { Reserve Cost } \\
\text { Savings }\end{array}$ \\
\hline & (\$/MWh) & (\$/MWh) & (\$/MWh) & $(\$ / y r)$ & (\$/yr) & (\$/yr) \\
\hline PJM 2006 & $\$ 7.30$ & $\$ 7.96$ & $\$ 8.29$ & $\$ 0.02$ & $\$ 0.16$ & $\$ 0.19$ \\
\hline ERCOT 2008 & $\$ 37.51$ & $\$ 25.61$ & $\$ 25.54$ & $\$ 0.11$ & $\$ 0.53$ & $\$ 0.64$ \\
\hline NYISO 2008 & $\$ 14.38$ & $\$ 9.56$ & $\$ 9.16$ & $\$ 0.04$ & $\$ 0.20$ & $\$ 0.24$ \\
\hline NYISO 2006 & $\$ 16.02$ & $\$ 5.97$ & $\$ 7.62$ & $\$ 0.05$ & $\$ 0.12$ & $\$ 0.17$ \\
\hline CAISO 2008 & $\$ 14.95$ & $\$ 4.78$ & $\$ 4.30$ & $\$ 0.04$ & $\$ 0.10$ & $\$ 0.14$ \\
\hline
\end{tabular}


The additional $3 \%$ pessimistic electricity consumption and cost savings resulting from providing energyuse feedback to customers is shown below in Table 4.49

Table 4-49. Additional 3\% Savings Resulting from CW Consumption Feedback to Customers

\begin{tabular}{|r|c|c|}
\hline Market and Year & $\mathbf{( k W h / y r )}$ & $\mathbf{( \$ / y r )}$ \\
\hline PJM 2006 & 4 & $\$ 0.19$ \\
\hline ERCOT 2008 & 4 & $\$ 0.34$ \\
\hline NYISO 2008 & 4 & $\$ 0.43$ \\
\hline NYISO 2006 & 4 & $\$ 0.32$ \\
\hline CAISO 2008 & 4 & $\$ 0.31$ \\
\hline
\end{tabular}

Finally, the overall low-end benefits (wholesale cost saving resulting from peak-load shifting, spinning reserves, and consumer feedback combined) are shown in Table 4.50 below.

Table 4-50. Smart CW Benefit (Peak Load Shift + Spinning Reserves + Feedback Effect)-to-Cost Ratio Pessimistic View

\begin{tabular}{|r|c|c|c|}
\hline & $\begin{array}{c}\text { Grid } \\
\text { Operational } \\
\text { Cost Savings } \\
\text { (Benefits) }\end{array}$ & $\begin{array}{c}\text { Cost of } \\
\text { Additional } \\
\text { Energy } \\
\text { Consumption } \\
\text { at 5\% Credit }\end{array}$ & $\begin{array}{c}\text { Benefits to } \\
\text { Cost Ratio }\end{array}$ \\
\cline { 2 - 4 } Market and Year & $\mathbf{( \$ / y r )}$ & $\mathbf{( \$ / y r )}$ & $(-)$ \\
\hline PJM 2006 & $\$ 0.42$ & $\$ 0.31$ & $\mathbf{1 3 5 \%}$ \\
\hline ERCOT 2008 & $\$ 1.17$ & $\$ 0.31$ & $\mathbf{3 7 2 \%}$ \\
\hline NYISO 2008 & $\$ 0.78$ & $\$ 0.31$ & $\mathbf{2 4 8 \%}$ \\
\hline NYISO 2006 & $\$ 0.58$ & $\$ 0.31$ & $\mathbf{1 8 4 \%}$ \\
\hline CAISO 2008 & $\$ 0.53$ & $\$ 0.31$ & $\mathbf{1 6 9 \%}$ \\
\hline & & & \\
\hline
\end{tabular}

Thus, as can be observed from Table 4.50, the benefits to cost ratios exceed $100 \%$ even for the pessimistic set of assumptions in all markets.

\subsection{Benefit-to-Cost Ratios: Smart Dishwashers (DWs)}

In this section, we estimate the benefit-to-cost ration of smart DWs in various markets based on both optimistic and pessimistic sets of assumptions. 


\subsubsection{High-End Optimistic Results}

We first present below in Table 4.51 the $\mathrm{CW}$ annual on-peak and off-peak electricity consumption, including the DW machine and DW water heater splits, based on the optimistic assumptions presented in Section 3.1.

Table 4-51. DW On-Peak and Off-Peak Consumption Based on ELCAP Average Annual Day Load Shape and Optimistic Assumptions

\begin{tabular}{|c|c|c|c|c|c|c|c|c|c|c|c|}
\hline \multicolumn{5}{|c|}{ ELCAP (1990) DishWasher Load Shape } & \multicolumn{7}{|c|}{2010 Annual DishWasher On-Peak and Off-Peak Consumption } \\
\hline Load Shape: & Average Day & Annual & & & \multirow{4}{*}{$\begin{array}{c}\text { Total Annual } \\
\text { Consumption } \\
\text { (Machine + Hot } \\
\text { Water) }\end{array}$} & \multirow{4}{*}{$\begin{array}{c}\text { Total Annual } \\
\text { Consumption } \\
\text { (Machine Only) }\end{array}$} & \multirow{4}{*}{$\begin{array}{c}\text { Total Annual } \\
\text { Consumption } \\
\text { (Hot Water } \\
\text { Only) }\end{array}$} & \multirow{4}{*}{$\begin{array}{l}\text { Annual On- } \\
\text { Peak } \\
\text { Consumption } \\
\text { (Machine } \\
\text { Only) }\end{array}$} & \multirow{4}{*}{$\begin{array}{l}\text { Annual Off- } \\
\text { Peak } \\
\text { Consumption } \\
\text { (Machine } \\
\text { Only) }\end{array}$} & \multirow{4}{*}{$\begin{array}{l}\text { Annual On- } \\
\text { Peak } \\
\text { Consumption } \\
\text { (Hot Water } \\
\text { Only) }\end{array}$} & \multirow{4}{*}{$\begin{array}{c}\text { Annual Off- } \\
\text { Peak } \\
\text { Consumption } \\
\text { (Hot Water } \\
\text { Only) }\end{array}$} \\
\hline & Daily Total & On-Peak & & & & & & & & & \\
\hline Start, Hour Ending: & 1 & 13 & Avg. No. of & Annual On- & & & & & & & \\
\hline Through Hour Ending: & 24 & 18 & $\begin{array}{l}\text { On-Peak } \\
\text { Days/Year }\end{array}$ & $\begin{array}{c}\text { Peak To } \\
\text { Total Ratio }\end{array}$ & & & & & & & \\
\hline & (kWh/day) & (kWh/day) & & & (kWh/yr) & (kWh/yr) & (kWh/yr) & (kWh/yr) & (kWh/yr) & (kWh/yr) & (kWh/yr) \\
\hline & 0.33 & 0.08 & 365 & 0.25 & 312 & 156 & 156 & 40 & 116 & 40 & 116 \\
\hline
\end{tabular}

Based on the data shown in Table 4.51, high-end wholesale power-production cost savings using smart CWs for peak load shifting are shown in Table 4.42 below. As was the case with the high-end savings for CWs shown in Table 4.42, we take into account the effect that splitting consumption between DW machine and DW water heating has on the savings.

Table 4-52. Wholesale Cost Savings from Using Smart DWs for Peak Load Shifting - Optimistic View

\begin{tabular}{|c|c|c|c|c|c|c|c|}
\hline \multirow[b]{3}{*}{ Market and Year } & \multicolumn{3}{|c|}{ Annual Hourly Energy Market Clearing Prices } & \multicolumn{2}{|c|}{$\begin{array}{l}\text { Annual Energy Cost } \\
\text { (No Load Shift) }\end{array}$} & \multicolumn{2}{|c|}{$\begin{array}{c}\text { Annual Energy Cost Savings from } \\
100 \% \text { Peak Load Shift }\end{array}$} \\
\hline & Avg. On-Peak & Avg. Off-Peak & $\begin{array}{c}\text { Avg. Shift-To } \\
\text { Hours }\end{array}$ & On-Peak & Off-Peak & $\begin{array}{c}\text { On-Peak } \\
\text { Energy Moved } \\
\text { to "Shift To" } \\
\text { Hours }\end{array}$ & Savings \\
\hline & (\$/MWh) & (\$/MWh) & (\$/MWh) & (\$/yr) & (\$/yr) & (kWh/yr) & (\$/yr) \\
\hline PJM 2006 & $\$ 50.64$ & $\$ 39.44$ & $\$ 39.44$ & $\$ 2.82$ & $\$ 6.42$ & 55.62 & $\$ 0.62$ \\
\hline ERCOT 2008 & $\$ 105.56$ & $\$ 67.09$ & $\$ 67.09$ & $\$ 5.87$ & $\$ 10.92$ & 55.62 & $\$ 2.14$ \\
\hline NYISO 2008 & $\$ 115.97$ & $\$ 92.25$ & $\$ 92.27$ & $\$ 6.45$ & $\$ 15.02$ & 55.62 & $\$ 1.32$ \\
\hline NYISO 2006 & $\$ 85.05$ & $\$ 67.44$ & $\$ 67.41$ & $\$ 4.73$ & $\$ 10.98$ & 55.62 & $\$ 0.98$ \\
\hline CAISO 2008 & $\$ 82.11$ & $\$ 65.01$ & $\$ 65.02$ & $\$ 4.57$ & $\$ 10.58$ & 55.62 & $\$ 0.95$ \\
\hline
\end{tabular}

The high-end wholesale cost savings from using smart DWs for providing spinning reserves is shown in Table 4.53 below. Once again, we take into account the effect that splitting consumption between DW machine and DW water heating has on the savings. 
Table 4-53. Wholesale Cost Savings from Using Smart CWs for Spinning Reserves - Optimistic View

\begin{tabular}{|c|c|c|c|c|c|c|}
\hline \multirow[b]{3}{*}{ Market and Year } & \multicolumn{3}{|c|}{ Annual Hourly SR Market Clearing Prices } & \multicolumn{3}{|c|}{ Annual DishWasher (Machine Only) SR Market Value } \\
\hline & Avg. On-Peak & Avg. Off-Peak & $\begin{array}{l}\text { Avg. Shift-To } \\
\text { Hours }\end{array}$ & $\begin{array}{l}\text { On Peak: From DishWasher } \\
\text { Load After } 100 \% \text { Shifted }\end{array}$ & $\begin{array}{l}\text { Off-Peak: From DishWasher Off } \\
\text { Peak Load + } 100 \% \text { Load shifted } \\
\text { from Peak to 'Shift To' Hours }\end{array}$ & $\begin{array}{c}\text { Total Spinning } \\
\text { Reserve Cost } \\
\text { Savings }\end{array}$ \\
\hline & (\$/MWh) & (\$/MWh) & (\$/MWh) & $(\$ / y r)$ & $(\$ / y r)$ & $(\$ / y r)$ \\
\hline PJM 2006 & $\$ 7.29$ & $\$ 8.08$ & $\$ 8.08$ & $\$ 0.00$ & $\$ 1.26$ & $\$ 1.26$ \\
\hline ERCOT 2008 & $\$ 36.85$ & $\$ 23.76$ & $\$ 23.76$ & $\$ 0.00$ & $\$ 3.71$ & $\$ 3.71$ \\
\hline NYISO 2008 & $\$ 14.84$ & $\$ 8.56$ & $\$ 8.56$ & $\$ 0.00$ & $\$ 1.34$ & $\$ 1.34$ \\
\hline NYISO 2006 & $\$ 12.40$ & $\$ 5.42$ & $\$ 5.42$ & $\$ 0.00$ & $\$ 0.85$ & $\$ 0.85$ \\
\hline CAISO 2008 & $\$ 13.26$ & $\$ 3.56$ & $\$ 3.57$ & $\$ 0.00$ & $\$ 0.56$ & $\$ 0.56$ \\
\hline
\end{tabular}

The additional $6 \%$ optimistic electricity consumption and cost savings resulting from providing energyuse feedback to customers is shown below in Table 4.54

Table 4-54. Additional 6\% Savings Resulting from DW Consumption Feedback to Customers

\begin{tabular}{|r|c|c|}
\hline Market and Year & $\mathbf{( k W h / y r )}$ & $\mathbf{( \$ / y r )}$ \\
\hline PJM 2006 & 13 & $\$ 0.55$ \\
\hline ERCOT 2008 & 13 & $\$ 1.01$ \\
\hline NYISO 2008 & 13 & $\$ 1.29$ \\
\hline NYISO 2006 & 13 & $\$ 0.94$ \\
\hline CAISO 2008 & 13 & $\$ 0.91$ \\
\hline
\end{tabular}

Finally, the overall high-end benefit (wholesale cost saving resulting from peak-load shifting, spinning reserves, and consumer feedback combined) are shown in Table 4.55 below.

Table 4-55. Smart CW Benefit (Peak Load Shift + Spinning Reserves + Feedback Effect)-to-Cost Ratio Optimistic View

\begin{tabular}{|r|c|c|c|}
\hline & $\begin{array}{c}\text { Grid } \\
\text { Operational } \\
\text { Cost Savings } \\
\text { (Benefits) }\end{array}$ & $\begin{array}{c}\text { Cost of } \\
\text { Additional } \\
\text { Energy } \\
\text { Consumption } \\
\text { at 5\% Credit }\end{array}$ & $\begin{array}{c}\text { Benefits to } \\
\text { Cost Ratio }\end{array}$ \\
\cline { 2 - 4 } Market and Year & $\mathbf{( \$ / y r )}$ & $\mathbf{( \$ / y r )}$ & $(-)$ \\
\hline PJM 2006 & $\$ 2.44$ & $\$ 0.46$ & $\mathbf{5 2 8 \%}$ \\
\hline ERCOT 2008 & $\$ 6.85$ & $\$ 0.46$ & $\mathbf{1 4 8 4 \%}$ \\
\hline NYISO 2008 & $\$ 3.94$ & $\$ 0.46$ & $\mathbf{8 5 4 \%}$ \\
\hline NYISO 2006 & $\$ 2.77$ & $\$ 0.46$ & $\mathbf{6 0 0 \%}$ \\
\hline CAISO 2008 & $\$ 2.42$ & $\$ 0.46$ & $\mathbf{5 2 3 \%}$ \\
\hline & & & \\
\hline
\end{tabular}


Thus, as can be observed from Table 4.55 , the benefit-to-cost ratios overwhelmingly exceed $100 \%$ in all markets.

\subsubsection{Low-End Pessimistic Results}

We first present below in Table 4.56 the annual on-peak and off-peak electricity consumption, including the DW machine and DW hot water splits, based on the pessimistic assumptions presented in Section 3.1.

Table 4-56. DW On-Peak and Off-Peak Consumption Based on ELCAP Average Annual Day Load Shape and Pessimistic Assumptions

\begin{tabular}{|c|c|c|c|c|c|c|c|c|c|c|c|}
\hline \multicolumn{5}{|c|}{ ELCAP (1990) DishWasher Load Shape } & \multicolumn{7}{|c|}{2010 Annual DishWasher On-Peak and Off-Peak Consumption } \\
\hline Load Shape: & Average Day & Annual & & & \multirow{4}{*}{$\begin{array}{c}\text { Total Annual } \\
\text { Consumption } \\
\text { (Machine + Hot } \\
\text { Water) }\end{array}$} & \multirow{4}{*}{$\begin{array}{c}\text { Total Annual } \\
\text { Consumption } \\
\text { (Machine Only) }\end{array}$} & \multirow{4}{*}{$\begin{array}{c}\text { Total Annual } \\
\text { Consumption } \\
\text { (Hot Water } \\
\text { Only) }\end{array}$} & \multirow{4}{*}{$\begin{array}{l}\text { Annual On- } \\
\text { Peak } \\
\text { Consumption } \\
\text { (Machine } \\
\text { Only) }\end{array}$} & \multirow{4}{*}{$\begin{array}{l}\text { Annual Off- } \\
\text { Peak } \\
\text { Consumption } \\
\text { (Machine } \\
\text { Only) }\end{array}$} & \multirow{4}{*}{$\begin{array}{l}\text { Annual On- } \\
\text { Peak } \\
\text { Consumption } \\
\text { (Hot Water } \\
\text { Only) }\end{array}$} & \multirow{4}{*}{$\begin{array}{c}\text { Annual Off- } \\
\text { Peak } \\
\text { Consumption } \\
\text { (Hot Water } \\
\text { Only) }\end{array}$} \\
\hline & Daily Total & On-Peak & & & & & & & & & \\
\hline Start, Hour Ending: & 1 & 14 & Avg. No. of & Annual On- & & & & & & & \\
\hline \multirow[t]{3}{*}{ Through Hour Ending: } & 24 & 17 & $\begin{array}{c}\text { On-Peak } \\
\text { Days/Year }\end{array}$ & $\begin{array}{c}\text { Peak To } \\
\text { Total Ratio }\end{array}$ & & & & & & & \\
\hline & (kWh/day) & (kWh/day) & & & (kWh/yr) & (kWh/yr) & (kWh/yr) & (kWh/yr) & (kWh/yr) & (kWh/yr) & (kWh/yr) \\
\hline & 0.33 & 0.05 & 261 & 0.12 & 312 & 156 & 156 & 18 & 138 & 18 & 138 \\
\hline
\end{tabular}

Based on the data shown in Table 4.56, high-end wholesale power production cost savings using smart DWs for peak load shifting are shown below in Table 4.57. Once again note that we take into account the effect that splitting consumption split between DW machine and DW water heating has on the savings.

Table 4-57. Wholesale Cost Savings from Using Smart CWs for Peak Load Shifting - Pessimistic View

\begin{tabular}{|c|c|c|c|c|c|c|c|}
\hline \multirow[b]{3}{*}{ Market and Year } & \multicolumn{3}{|c|}{ Annual Hourly Energy Market Clearing Prices } & \multicolumn{2}{|c|}{$\begin{array}{l}\text { Annual Energy Cost } \\
\text { (No Load Shift) }\end{array}$} & \multicolumn{2}{|c|}{$\begin{array}{c}\text { Annual Energy Cost Savings from } \\
25 \% \text { Peak Load Shift }\end{array}$} \\
\hline & Avg. On-Peak & Avg. Off-Peak & $\begin{array}{c}\text { Avg. Shift-To } \\
\text { Hours }\end{array}$ & On-Peak & Off-Peak & $\begin{array}{c}\text { On-Peak } \\
\text { Energy Moved } \\
\text { to "Shift To" } \\
\text { Hours }\end{array}$ & Savings \\
\hline & (\$/MWh) & (\$/MWh) & (\$/MWh) & $(\$ / y r)$ & $(\$ / y r)$ & (kWh/yr) & (\$/yr) \\
\hline PJM 2006 & $\$ 55.55$ & $\$ 40.45$ & $\$ 42.90$ & $\$ 1.41$ & $\$ 7.80$ & 6.24 & $\$ 0.08$ \\
\hline ERCOT 2008 & $\$ 119.27$ & $\$ 70.95$ & $\$ 73.03$ & $\$ 3.04$ & $\$ 13.69$ & 6.24 & $\$ 0.29$ \\
\hline NYISO 2008 & $\$ 120.56$ & $\$ 95.16$ & $\$ 94.83$ & $\$ 3.07$ & $\$ 18.36$ & 6.24 & $\$ 0.16$ \\
\hline NYISO 2006 & $\$ 93.91$ & $\$ 68.87$ & $\$ 72.50$ & $\$ 2.39$ & $\$ 13.29$ & 6.24 & $\$ 0.13$ \\
\hline CAISO 2008 & $\$ 88.25$ & $\$ 66.72$ & $\$ 68.67$ & $\$ 2.25$ & $\$ 12.87$ & 6.24 & $\$ 0.12$ \\
\hline
\end{tabular}

The low-end wholesale cost savings from using smart DWs for providing spinning reserves is shown in Table 4.58 below. Once again note that we take into account the effect that splitting consumption between DW machine and DW water heating has on the savings. 
Table 4-58. Wholesale Cost Savings from Using Smart CWs for Spinning Reserves - Pessimistic View

\begin{tabular}{|c|c|c|c|c|c|c|}
\hline \multirow[b]{3}{*}{ Market and Year } & \multicolumn{3}{|c|}{ Annual Hourly SR Market Clearing Prices } & \multicolumn{3}{|c|}{ Annual DishWasher (Machine Only) SR Market Value } \\
\hline & Avg. On-Peak & Avg. Off-Peak & $\begin{array}{l}\text { Avg. Shift-To } \\
\text { Hours }\end{array}$ & $\begin{array}{l}\text { On Peak: From DishWasher } \\
\text { Load After 25\% Shifted }\end{array}$ & $\begin{array}{c}\text { Off-Peak: From DishWasher Off } \\
\text { Peak Load + 25\% Load shifted } \\
\text { from Peak to 'Shift To' Hours }\end{array}$ & $\begin{array}{c}\text { Total Spinning } \\
\text { Reserve Cost } \\
\text { Savings }\end{array}$ \\
\hline & (\$/MWh) & (\$/MWh) & (\$/MWh) & $(\$ / y r)$ & $(\$ / y r)$ & $(\$ / y r)$ \\
\hline PJM 2006 & $\$ 7.30$ & $\$ 7.96$ & $\$ 8.29$ & $\$ 0.02$ & $\$ 0.26$ & $\$ 0.28$ \\
\hline ERCOT 2008 & $\$ 37.51$ & $\$ 25.61$ & $\$ 25.54$ & $\$ 0.12$ & $\$ 0.82$ & $\$ 0.94$ \\
\hline NYISO 2008 & $\$ 14.38$ & $\$ 9.56$ & $\$ 9.16$ & $\$ 0.04$ & $\$ 0.31$ & $\$ 0.35$ \\
\hline NYISO 2006 & $\$ 16.02$ & $\$ 5.97$ & $\$ 7.62$ & $\$ 0.05$ & $\$ 0.19$ & $\$ 0.24$ \\
\hline CAISO 2008 & $\$ 14.95$ & $\$ 4.78$ & $\$ 4.30$ & $\$ 0.05$ & $\$ 0.15$ & $\$ 0.20$ \\
\hline
\end{tabular}

The additional $3 \%$ pessimistic electricity consumption and cost savings resulting from providing energyuse feedback to customers is shown below in Table 4.59.

Table 4-59. Additional 3\% Savings Resulting from DW Consumption Feedback to Customers

\begin{tabular}{|r|c|c|}
\hline Market and Year & $\mathbf{( k W h / y r )}$ & $\mathbf{( \$ / y r )}$ \\
\hline PJM 2006 & 7 & $\$ 0.28$ \\
\hline ERCOT 2008 & 7 & $\$ 0.50$ \\
\hline NYISO 2008 & 7 & $\$ 0.64$ \\
\hline NYISO 2006 & 7 & $\$ 0.47$ \\
\hline CAISO 2008 & 7 & $\$ 0.45$ \\
\hline
\end{tabular}

Finally, the overall low-end benefits (wholesale cost saving resulting from peak-load shifting, spinning reserves, and consumer feedback combined) are shown in Table 4.60 below. 
Table 4-60. Smart DW Benefit (Peak Load Shift + Spinning Reserves + Feedback Effect)-to-Cost Ratio Pessimistic View

\begin{tabular}{|r|c|c|c|}
\hline & $\begin{array}{c}\text { Grid } \\
\text { Operational } \\
\text { Cost Savings } \\
\text { (Benefits) }\end{array}$ & $\begin{array}{c}\text { Cost of } \\
\text { Additional } \\
\text { Energy } \\
\text { Consumption } \\
\text { at 5\% Credit }\end{array}$ & $\begin{array}{c}\text { Benefits to } \\
\text { Cost Ratio }\end{array}$ \\
\cline { 2 - 4 } Market and Year & $(\$ / y r)$ & $(\$ / y r)$ & $(-)$ \\
\hline PJM 2006 & $\$ 0.63$ & $\$ 0.46$ & $137 \%$ \\
\hline ERCOT 2008 & $\$ 1.73$ & $\$ 0.46$ & $\mathbf{3 7 4 \%}$ \\
\hline NYISO 2008 & $\$ 1.15$ & $\$ 0.46$ & $\mathbf{2 5 0 \%}$ \\
\hline NYISO 2006 & $\$ 0.85$ & $\$ 0.46$ & $\mathbf{1 8 4 \%}$ \\
\hline CAISO 2008 & $\$ 0.77$ & $\$ 0.46$ & $168 \%$ \\
\hline & & & \\
\hline
\end{tabular}

Thus, as can be observed from Table 4.60, the benefits to cost ratios exceed $100 \%$ even for the pessimistic set of assumptions in all markets. 


\subsection{Conclusions and Future Work}

In this report, we presented the results of an analytical cost/benefit study of residential "smart appliances" from a utility/grid perspective in support of a joint-stakeholder petition to the EPA and DOE. Benefits were defined as the savings in wholesale power-production costs resulting from smart appliances shifting their operation from peak to off-peak hours, and smart appliances providing spinning reserves through temporary curtailment of their operation. Cost was defined as the credit the petition was seeking when applied to annual operating cost of each appliance.

We first presented our cost/benefit analytical model in general, and then we applied this model to individual appliances to evaluate their benefit-to-cost ratios. In estimating benefits and costs, we made some input assumptions, and presented a rationale for the values chosen. We also presented the annual load shape of each appliance, based on which the cost/benefit model was formulated. Finally, benefits and costs were estimated based on historical wholesale market clearing prices from several major markets in the U.S. From the benefit-to-cost ratio for each appliance, we observed that for all appliances, the benefit-to-cost ratios far exceeded $100 \%$. This indicates that benefits outweigh the costs, and the credit is cost-effective.

It must be emphasized that in the work we have shown that the use of smart appliances leads to power grid benefits manifested as savings in wholesale power production costs. These savings can then be passed on to rate-paying customers. The next step would be to continue this cost/benefit analysis to understand and quantify how these wholesale grid operating-cost savings translate into net customer benefits at the retail level. 



\subsection{References}

American Council for an Energy Efficient Economy (ACEEE). 2010. Advanced Metering Initiatives andResidential Feedback Programs: A Meta-Review for Household Electricity-Saving Opportunities. Available at http://www.aceee.org/research-report/e105.

Association of Home Appliance Manufacturers (AHAM). 2009. Shipment Weighted Average Data. Personal communication with AHAM.

Association of Home Appliance Manufacturers (AHAM). 2010. Assessment of Communication Standards for Smart Appliances: The Home Appliance Industry's Technical Evaluation of Communication

Protocols. Washington, D.C. Accessed December 9, 2010 at

http://www.aham.org/ht/a/GetDocumentAction/i/50696

California Independent System Operator (CAISO). 2008. OASIS. Accessed December 9, 2010 at http://oasishis.caiso.com/.

U.S. Department of Energy (DOE). 2010. Appliances \& Commercial Equipment Standards. Accessed November 29, 2010 at

http://www1.eere.energy.gov/buildings/appliance_standards/residential_products.html (last updated May 11,2010

U.S. Department of Energy (DOE). 2010a. Press Release, U.S. Department of Energy, Secretary Chu Announces Two Million Smart Grid Meters Installed Nationwide (August 31, 2010). Washington, D.C. Accessed September 30, 2010 at http://www.energy.gov/news/9433.htm.

U.S. Department of Energy (DOE). 2010b. 20\% Wind Energy by 2030: Increasing Wind Energy's Contribution to U.S. Electricity Supply. Accessed September 30, 2010 at http://www1.eere.energy.gov/windandhydro/wind_2030.html.

US Department of Energy, Office of Energy Efficiency and Renewable Energy (EERE). 2009. "2006 Residential Energy End-Use Splits by Fuel Type - Table 2.1.5. Buildings Energy Data Book. Accessed October 14, 2010 at http://buildingsdatabook.eren.doe.gov/TableView.aspx?table=2.1.5 (last updated October, 2009).

Energy Information Administration (EIA). 2010. U.S. Energy Information Administration, Annual Energy Outlook 2010. Projection and analysis of US energy supply, demand, and prices through 2035. Accessed September 30, 2010 at http://www.eia.doe.gov/oiaf/aeo/ (last updated May 11, 2010).

Electric Reliability Council of Texas (ERCOT). 2008. Ancillary Services Offer Selected - Daily Reports Archive. Accessed December 9, 2010 at http://www.ercot.com/mktinfo/prices/asoffer/2008/index.

Eto JH, J Nelson-Hoffman, C Torres, S Hirth, B Yinger, J Kueck, B Kirby, C Bernier, R Wright, A Barat, and DS Watson. 2007. Demand Response Spinning Reserve Demonstration. LBNL-62761. Ernest Orlando Lawrence Berkeley National Laboratory, Berkeley, California. 
Faruqui A, S Sergici, and A Sharif. 2009. “The Impact of Informational Feedback on Energy Consumption - A Survey of the Experimental Evidence." Energy (in press).

Federal Energy Regulatory Commission (FERC). 2009. A National Assessment of Demand Response Potential. FERC June 2009 Staff Report. Accessed November 26, 2010 at http:// www.ferc.gov/legal/staff-reports/06-09-demand-response.pdf.

Fischer C. 2008. "Feedback on Household Electricity Consumption: A Tool for Saving Energy?" Energy Efficiency 1(1):79-104. DOI: 10.1007/s12053-008-9009-7. Accessed December 9, 2010 at www.springerlink.com/index/276m42024x61wh1h.pdf.

Kirby BJ and JD Kueck. 2003. Spinning Reserve from Pump Load: A Technical Findings Report to the California Department of Water Resources. ORNL/TM-2003/99, Oak Ridge National Laboratory, Oak Ridge, Tennessee.

Kirby BJ. 2003. Spinning Reserve from Responsive Loads. ORNL/TM-2003/19, Oak Ridge National Laboratory, Oak Ridge, Tennessee.

Kueck JD, BJ Kirby, MR Ally, and CK Rice. 2008. Prediction of Air Conditioning Load Response for Providing Spinning Reserve. ORNL/TM-2008/227, Oak Ridge National Laboratory, Oak Ridge, Tennessee.

North American Electricity Reliability Corporation (NERC). 2002. Control Performance Standards. Accessed September 30, 2010 at http://www.nerc.com/docs/oc/ps/tutorcps.pdf.

North American Electricity Reliability Corporation (NERC). 2005. Disturbance Control Performance 2005. BAL-002-0. Accessed October 04, 2010 at http:// www.nerc.com/files/BAL-002-0.pdf.

New York Independent System Operator (NYISO). 2006 and 2008. Markets and Operations -Custom Reports - Real-Time Market - Ancillary Services. Accessed December 9, 2010 at http://www.nyiso.com/public/markets_operations/market_data/custom_report/index.jsp?report=rt_ancillar y.

PJM. 2006. Mid-Atlantic Synchronized Reserve Zone Preliminary Billing Data. Accessed December 9, 2010 at http://www.pjm.com/markets-and-operations/market-settlements/preliminary-billing-reports/eastspinning-reserve.aspx.

Pratt RG, CC Conner, EE Richman, KG Ritland, WF Sandusky, and ME Taylor. 1989. Description of Electric Energy Use in Single-Family Residences in the Pacific Northwest. (End-Use Load and Consumer Assessment Program [ELCAP]). DOE/BP-13795-21, prepared for Bonneville Power Administration by Pacific Northwest Laboratory, Richland, Washington.

Western Electricity Coordinating Council (WECC). 2006. NERC/WECC Minimum Operating Reliability Standards, Standart BAL-STD-002-1 — Disturbance Control Performance. 2006. Accessed October 14, 2010 at http://www.wecc.biz/Documents/2006/Standards/BAL-STD-0021 _ORSTF_Version_Approved_by_MIC_October_2006.pdf. 
Wellinghoff J, DL Morenoff and ME Tighe. 2008. Creating Regulatory Structures for Robust Demand Response Participation in Organized Wholesale Electric Markets. Federal Energy Regulatory

Commission (FERC). Accessed November 26, 2010 at http://www.ferc.gov/about/commem/wellinghoff/ACEEE_article.pdf 



\section{Distribution}

No. of

Copies

\# Name

Organization

Address

City, State and ZIP Code

\# Organization

Address

City, State and ZIP Code

Name

Name

Name

Name

Name (\#)

\# Name

Organization

Address

City, State and ZIP Code
No. of

Copies

\# Foreign Distribution

\# Name

Organization

Address

Address line 2

COUNTRY

\# Local Distribution

Pacific Northwest National Laboratory

Name

Name

Name

Name

Name
Mailstop

Mailstop

Mailstop

Mailstop

(PDF) 




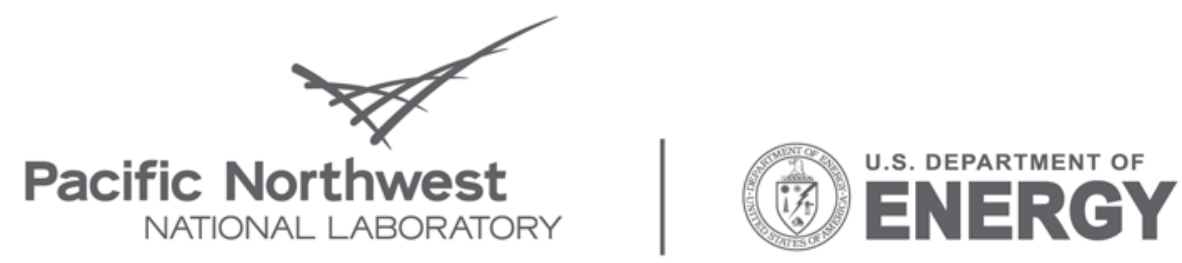

Proudly Operated by Battelle Since 1965

902 Battelle Boulevard

P.O. Box 999

Richland, WA 99352

1-888-375-PNNL (7665)

www.pnl.gov 